\title{
Diversity and its Discontents: The End of Affirmative Action at Boalt Hall
}

\author{
By Rachel F. Moran $\dagger$
}

\section{TABLe of Contents}

I. The Legal Rationale for Affirmative Action: A Pedagogy

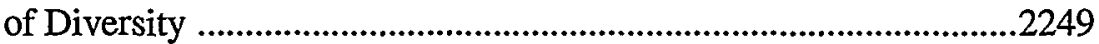

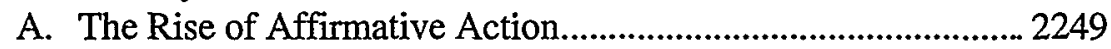

B. Early Challenges to Affirmative Action....................................2251

C. Current Challenges to Affirmative Action ................................2253

II. Social Science Evidence on Diversity and the Learning Process ....2257

A. Student Achievement During School ..........................................2257

B. Student Achievement After Graduation ..................................2259

C. Student Attitudes .......................................................................2263

D. Qualitative Studies Based On Interviews and Focus Groups....2267

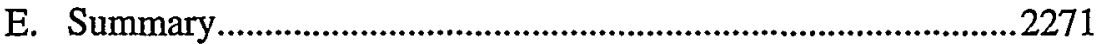

III. The Boalt Hall Interview Project .................................................. 2272

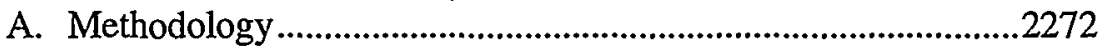

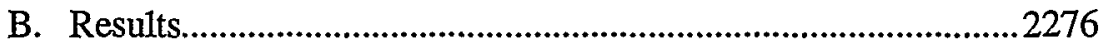

1. Reasons for Attending Law School ......................................2276

a. Detached Reasons for Coming to Law School ...............22276

b. Engaged Reasons for Coming to Law School ................2278

c. Powell's Vision and Reasons for Coming to Law

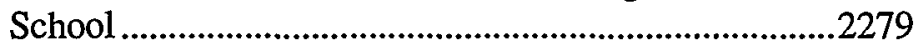

Copyright $\odot 2000$ California Law Review, Inc. California Law Review, Incorporated (CLR) is a California nonprofit corporation. CLR and the authors are solely responsible for the content of their publications.

$\dagger \quad$ Robert D. and Leslie-Kay Raven Professor of Law, School of Law, University of California, Berkeley (Boalt Hall). A.B., 1978, Stanford University; J.D., 1981, Yale Law School. I want to thank the Law School for its support of this research project. I especially want to thank the interviewers, Stephanie Bornstein, Ernest Ceberio, Rochelle Dunham, Michelle Fang, Caitlin Liu, John Park, and Tirien Steinbach, and the administrative staff, Priscilla Battis and Dana Herrera, who made this project possible. Judith Wegner also generously shared materials from a database on legal education compiled for a Carnegie Foundation initiative on law teaching. I also appreciate the opportunity to present an earlier version of this paper at the Association of American Law Schools Annual Meeting, Boalt Hall, McGeorge School of Law, the University of Houston Law Center, and the University of Texas Law School. A very special thanks goes to Simran Bindra for his careful editing of this piece. 
2. Classroom Experience.......................................................... 2279

a. Student Reactions to the First-Year Instructional Process ...................................................................2280

b. Recollections of Specific Cases Taught in the First-Year Curriculum .......................................................2284

i. Cases that Evoked Little Discussion of Race or Gender. .................................................................2284

ii. Cases that Evoked Some Discussion of Race

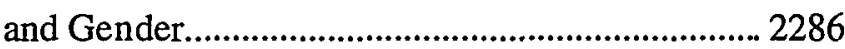

iii. The Special Case of Criminal Law .........................2289

iv. The Implications of the Vignettes for Powell's Pedagogy of Diversity ...............................................2293

3. Contact with Faculty ..........................................................2295

a. Reasons for the Lack of Mentoring Relationships .......2295

b. The Relevance of Race and Gender to Mentoring Relationships ..................................................................2297

c. The Roots of the Divide Between Faculty and

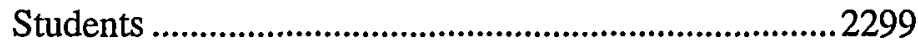

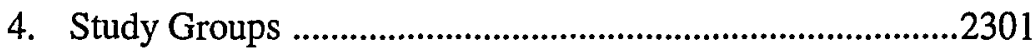

a. Race, Gender and the Formation of Study Groups.......2301

b. The Limited Role of Study Groups in Promoting a Pedagogy of Diversity ....................................................2304

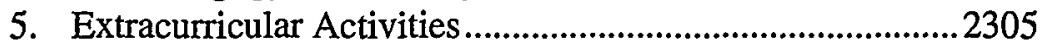

a. Race, Gender and the Nature of Organizational Involvement...............................................................2306

b. Racial and Ethnic Parity: A Tale of Two Journals ......2308

c. The Impact of Colorblind Admission on Racial and Ethnic Organizations ......................................................2311

d. Student Organizations and the Partial Realization of Powell's Vision ............................................................2313

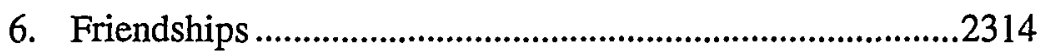

a. The Lonely Crowd.........................................................2314

b. Patterns of Friendship and Self-Segregation ..................2315

c. Friendships, Balkanization, and the Exchange of Ideas ........................................................................2320

7. Views About Affirmative Action in Admissions.................2321

a. The Pros and Cons of Affirmative Action.....................2321

b. The Uncertain Meaning of Merit...................................2325

c. The Adequacy of the Law School's Response to Changes in Admissions Policy ......................................22327

d. Normative Ambiguity and Shifting Support for Affirmative Action 
IV. The Unfulfilled Promise of Diversity and Legal Education:

The Lessons of Boalt Hall's Experience

Conclusion . 


\title{
Diversity and its Discontents: The End of Affirmative Action at Boalt Hall
}

\author{
By Rachel F. Moran
}

In 1995, the Regents of the University of California abolished the use of racial, ethnic, and gender preferences in admissions. The following year, the state's voters cemented the Regents' decision by constitutionalizing the ban on preferences. In response, Boalt Hall did away with its affirmative action program. The impact was immediate and dramatic. In 1997, the entering class included only one Black student and fourteen Latino students. Although these numbers increased somewhat in succeeding admissions cycles, the representation of Black and Latino students remains substantially below what it was when affirmative action was permissible.

In Regents of the University of California v. Bakke, Justice Lewis Powell justified affirmative action programs on the basis of the pedagogical benefits that a diverse student body brings. The sudden shift in Boalt's admissions policy provided an unprecedented opportunity to gauge the impact of diversity on legal education. In the spring of 1998, fifty-nine Boalt students participated in hour-long interviews that explored their reasons for coming to law school, their classroom experience, their relations with faculty, their participation in study groups and extracurricular activities, their friendships, and their views on admissions policy.

The results reveal that even with affirmative action, hierarchical instruction and competition for grades and other credentials have made it difficult to realize Powell's vision of a diverse pedagogy, at least in the first year of law school. When students draw on their identity and perspective, they sometimes are limited to the margins of the educational process, for example, in student-sponsored organizations and activities. Racial and ethnic organizations have been blamed for balkanizing the student body. As affirmative action draws to a close, however, students recognize that Black students in particular may become tokenized and that Whites and Asian Americans may form separate cliques. As a result, Boalt will not necessarily reap the benefits of colorblindness that the end of affirmative action was supposed to achieve. 
Choosing I reject, there is no other way, yet that which I reject is more numerous, more dense, more clamorous than ever before.

-Wislawa Szymborska'

As Boalt Hall enters the twenty-first century, it faces an unprecedented challenge. It is the premier public law school in the most diverse state in the nation, but its own student body no longer reflects the racial and ethnic complexity of California's population. This challenge is rooted in political changes made on the eve of the new millennium. On July 20 , 1995 , the Regents of the University of California voted to end all preferences based on race, ethnicity, and gender in admissions, hiring, and contracting. ${ }^{2}$ The following year, California voters by a margin of fifty-four to forty-six percent ${ }^{3}$ amended the state constitution to abolish these preferences in all aspects of state decision making. ${ }^{4}$ After the Ninth Circuit Court of Appeals found that the amendment did not violate federal law, ${ }^{5}$ affirniative action was effectively dead at the University of California.

This Essay focuses on the impact of this change on the educational experiences of students at Boalt Hall, which is located at the Berkeley campus. Before the implementation of the Regents' resolution and the voters' popular initiative, Boalt was among the most racially and ethnically diverse elite law schools in the country. ${ }^{6}$ In 1996 , the last year in which affirmative action was permissible, the admissions process produced a

1. Wislawa Szymborska, A Great Number, in Sounds, Feelings, Thoughts: Seventy Poems by Wislawa SzymborsKa 151, 11. 15-17 (Magnus J. Krynski \& Robert A. Maguire trans., 1981).

2. See The Regents of the University of California, Policy Ensuring Equal Treatment: Admissions (SP-1) (July 20, 1995); The Regents of the University of California, Policy Ensuring Equal Treatment: Employment and Contracting (SP-2) (July 20, 1995).

3. See Dave Lesher, Battle Over Prop. 209 Moves to the Courts, L.A. Times, Nov. 7, 1996, at A1.

4. See Proposition 209 (November 5, 1996) (codified at CAL. CoNST. art. I, § 31). Affirmativc action is permissible in California governmental activities only to the extent required by federal law. For example, a state or municipal agency under a federal court order could continue to implement mandated affirmative action policies. See CAL. Const. art. I, § 3 I (d), (e). The State of Washington adopted a similar initiative in 1998, which eliminated the use of affirmative action at its public colleges and universities as well. See Tom Brune and Joe Heim, Initiative 200: New Battle Begins: Interpreting Law, Seatrle Times, Nov. 4, 1998, at BI; Tom Brune, Now That I-200 Is Law, What's Next?: UW Alters Admission Policy, Seatrle Trmes, Nov. 5, 1998, at Al. A ballot initiative similar to California's was proposed for the November 2000 ballot in Florida, but Governor Jeb Bush chose to deflect the effort by issuing an executive order that ended all "race or gender set-asides, preferences, or quotas" in state contracts, and college and university admissions. Matthew Rees, "One Florida": Many Problems, WKLY. STANDARD, May 15, 2000, at 27.

5. See Coalition for Econ. Equity v. Wilson, 946 F. Supp. 1480 (N.D. Cal. 1996), rev'd, 122 F.3d 692 (9th Cir. 1997), cert. denied, 522 U.S. 963 (1997).

6. See Kate Rix, Finding Boalt's Pressure Points, The Recorder, July 23, 1997, at 1 (describing Boalt as "until recently one of the most diverse major law schools in the country"). 
class of 263 students, which included 20 Blacks, 28 Latinos, $^{7} 4$ Native Americans, and 38 Asian Americans. Together, these groups accounted for thirty-four percent of the students in Boalt's entering class. ${ }^{8}$ In 1997, the first year in which affirmative action was abolished, the change was dramatic. The new admissions process yielded a group of 243 students, of whom none were Black, 7 were Latino, none were Native American, and 32 were Asian American. The drop in Latino enrollments was due primarily to a marked decline in the number of Chicanos, that is, students of Mexican origin. Non-White students made up $23 \%$ of those admitted and enrolled. ${ }^{9}$ In fact, the lone Black student and half of the Latino students who were members of the Class of 2000 were deferred admits, individuals who had been admitted under a policy that permitted affirmative action but had chosen to delay their enrollment. ${ }^{10}$

Partly in response to intensely negative publicity, ${ }^{11}$ Boalt Hall convened an Admissions Policy Task Force during the 1997-1998 school year to reassess the policies and practices that had produced a class which, without deferred admits, would have included neither Black nor Native American students and only a handful of Latino students. The Task Force recommended a variety of incremental changes, most of which the law school adopted. These changes generally were designed to reduce the weight attached to quantitative criteria like undergraduate grade-point averages and Law School Admissions Test (LSAT) scores by enhancing the scope of discretionary decision making by members of the Admissions Committee. ${ }^{12}$ In addition, the law school instituted an experimental

7. Throughout this paper, the term "Latino" is used to refer to all students of Hispanic origin. When an important difference among subgroups occurs, it will be noted.

8. See The University of California at Berkeley School of Law (Boalt Hall), 1996 Annual Admissions Report 2 (1996) (on file with author) [hereinafter 1996 Admissions Report].

9. See The University of California at Berkeley School of Law (Boalt Hall), 1997 Annual Admissions Report 4 (1997) (on file with author) [hereinafter 1997 Admissions Report].

10. See The University of California at Berkeley School of Law (Boalt Hall), 1998 Annual Admissions Report tbl.IV (1998) (on file with author) [hereinafter 1998 Admissions Report] (noting that one Black and fourteen Latinos enrolled in the Class of 1997). Of these, the lone Black student and seven Latino students were deferred admits. See 1997 Admissions Report, supra note 9, at 12.

11. See, e.g., Annie Nakao, Diversity Lacking as Boalt Hall Opens, S.F. EXAMINER, Aug. 19, 1997, at A1 (noting student protests at the "stunningly small numbers of underrepresented minorities"); Why Boalt Hall Failed and Others Succeeded, S.F. CHRON., Aug. 20, 1997, at A20 (discussing how "vigorous efforts" could "mean the difference between classes with a healthy representation of underrepresented minorities and those with a "shameful few").

12. These changes included eliminating the practice of adjusting an applicant's undergraduate grade-point average based on the competitiveness of the institution at which it was achieved. An institution's competitiveness was judged by the average LSAT score of test-takers from that college or university. The Law School used score bands indicating the range of error represented by an LSAT score and considered whether applicants with low LSAT scores and high grades had a history of poor performance on standardized tests that led to underprediction of their academic performance. The use of ranges that labeled candidates as A (high grades, high LSAT) to D (relatively low grades, low LSAT) was also dropped. In addition, the Law School expanded its use of the personal statement to make subjective judgments about applicants, referred more applicants' files to the Admissions 
program that gave separate consideration to socioeconomically disadvantaged students. These students met minimum academic requirements but would not have been admitted without special treatment based on their history of disadvantage. Up to 30 students could receive offers of admission under this program. ${ }^{13}$ With these policy reforms in place, Boalt admitted a class of 269 students, of whom 8 were Black, 23 were Latino, 2 were Native American, and 48 were Asian American. ${ }^{14}$ These students made up $30 \%$ of the entering class. According to public statements by Dean Herma Hill Kay, the program for socioeconomically disadvantaged students primarily benefited Whites and Asian Americans..$^{15}$ The program, therefore, did little to boost the representation of Blacks and Latinos at Boalt Hall. ${ }^{16}$

These figures represent the high-water mark in representation of nonWhite students at Boalt in a post-affirmative action world. Although the experiment with a separate program for socioeconomically disadvantaged students was abandoned after one year, the other reforms remained in place when admitting the entering class of $1999 .{ }^{17}$ That year, in a class of 269 students, only 7 were Black, 16 were Latino, 2 were Native American, and 35 were Asian American. ${ }^{18}$ Non-White students accounted for $22 \%$ of the student body. These statistics suggest that Boalt will find it difficult to achieve the levels of diversity that it had when race and ethnicity could be considered in the admissions process. The problem will be especially acute for Black and Latino students, despite the law school's efforts to amend its policies and practices in ways that expand the scope of discretionary, subjective judgments about individual applicants. For the foreseeable future,

Committee, and offered training on reading files to members of the Admissions Committee. This training was designed to promote uniform review, avoid overreliance on numerical indicators, and ensure that accomplishments and disadvantages related to race (as opposed to racial identification alone) received proper consideration. See Report of an Ad Hoc Task Force on Diversity in Admissions to the Dean and the Admissions Committee of the University of California, School of Law, Berkeley (Oct. 14, 1997) (on file with the Garret W. McEnerney (Boalt Hall) Law Library); Memorandum from Professor Robert Post to the Faculty (Dec. 10, 1997) (on file with author); see also 1998 Admissions Report, supra note 10, at apps. Boalt Hall Admission Procedures, Boalt Hall Supplemental Admission Criteria (noting adoption of amendments to admissions procedures and criteria in December 1997).

13. See 1998 Admissions Report, supra note 10, app. Boalt Hall Admission Procedures at 3.

14. See 1998 Admissions Report, supra note 10, at tbl.IV.

15. See Kenneth R. Weiss, Connerly Takes on Boalt Hall Dean,L.A. T1MEs, June 19, 1998, at A3.

16. See id.

17. See The University of California at Berkeley School of Law (Boalt Hall), 1999 Annual Admissions Report 1 (1999) (on file with author) [hereinafter 1999 Admissions Report]; see also Report of an Ad Hoc Group on the Law School's 1997-98 Experiment with Socioeconomic Admissions to the Faculty (Dec. 10, 1998) (on file with author) [hereinafter Report on Sociocconomic Admissions] (describing the results of relying on socioeconomic status in a separate admissions process).

18. See 1999 Admissions Report, supra note 17, at tbl.IV. 
then, Whites will dominate the student body, and only Asian Americans will constitute a minority that substantially exceeds $5 \%$ of those enrolled.

Missing from all of these statistical accounts, however, is some sense of how these changes have affected the educational and social climate at the law school. ${ }^{19}$ This Essay begins to fill that gap by reporting the results of interviews with first-, second-, and third-year students in the spring semester of 1998. While the second- and third-year students had been admitted under a process that included affirmative action, the first-year students (with the exception of the deferred admits) were selected without regard to race or ethnicity. The interviews dealt with diversity's impact both inside and outside the classroom, covering the first-year academic experience, study groups, extracurricular activities, social life, and the admissions process itself. The questions were designed to elicit students' views about whether racial or ethnic diversity had any significant impact on their legal education, thereby testing the premise that diversity positively affects the way that students learn. This assumption has been crucial to the constitutional legitimacy of affirmative action, as courts have shifted from an emphasis on correcting past wrongs to promoting the exchange of ideas to justify efforts to diversify higher education.

I.

\section{The Legal Rationale for Affirmative Action: A Pedagogy of DIVERSITY}

\section{A. The Rise of Affirmative Action}

Boalt's affirmative action program grew out of larger legal, social, and political efforts to rectify past discrimination, particularly the legacy of de jure segregation that compelled Whites and Blacks to live apart by law following Reconstruction..$^{20}$ In 1896, the United States Supreme Court upheld this racial caste system in Plessy v. Ferguson, ${ }^{21}$ concluding that separate facilities were not inherently unequal and that Blacks were stigmatized only to the extent that they chose to interpret their treatment as demeaning. ${ }^{22}$ It took over fifty years for the Court to recover from this fundamental error.

19. In 1999, a volume of essays by Boalt students described their reactions to the end of affirmative action at the law school. THE Diversity HOAX: LAW STUDENTS REPORT FROM BERKELEY (David Wienir \& Marc Berley eds., 1999). Unfortunately, there was no effort to ensure that the student contributors were representative or that they addressed a common set of issues. The call for submissions to the then-titled "Berkeley Federalist Law Papers" highlighted issues of censorship and silencing, id. at 37-38, but the editor cautioned that because of the way the project was done, "[e]ach essay is subjective and speaks only for itself." Id. at 30 .

20. See Richard Kluger, Simple Justice 27-123 (Vintage Books 1977) (1976); J. Harvie Wilkinson III, From Brown to Bakke: The Supreme Court and School Integration: 19541978, at 11-23 (1979).

21. 163 U.S. 537 (1896).

22. See id. at 551 . 
In the late 1930s, the National Association for the Advancement of Colored People (NAACP) began to bring lawsuits challenging segregated conditions in higher education. The NAACP considered colleges and universities a particularly promising place to begin the campaign to end de jure segregation because the rich academic offerings in all-White institutions could not easily be duplicated in separate Black institutions. ${ }^{23}$ This strategy proved successful. In 1938, the Court found that Missouri could not bar Black students from its state law school and instead provide them with the cost of tuition at an out-of-state school. ${ }^{24}$ This policy violated the Fourteenth Amendment's Equal Protection Clause because it prevented Blacks from enjoying the same access to legal education within the state that Whites did. In 1950, the Court held that Blacks could not be excluded from the Umiversity of Texas Law School by establishing a separate state institution for them..$^{25}$ Students at the Black school had a less renowned faculty, fewer library books, and less impressive facilities than their counterparts at the University of Texas. Even if these tangible resources were equalized, the Court reasoned, Black students were denied access to the network of influential alumni that Whites enjoyed by virtue of the University of Texas' long and distinguished history in the state. ${ }^{26}$

The successes in these higher education cases paved the way for Brown v. Board of Education, ${ }^{27}$ which declared that "[s] eparate educational facilities are inherently unequal." ${ }^{28}$ Emphasizing not only the tangible differences in resources and facilities but also the intangible injuries to "hearts and minds" associated with racial exclusion, Chief Justice Earl Warren wrote for a unamimous Court in striking down de jure segregation of public elementary and secondary schools as a violation of the Equal Protection Clause. ${ }^{29}$ What followed was an arduous process of implementing the Court's mandate that schools be integrated and that past discrimination be eliminated "root and branch. ${ }^{.30}$ Eventually, the Court's efforts were invigorated by the Civil Rights Act of 1964, which enlisted Congress and federal agencies in the quest for integration. ${ }^{31}$

23. See KLUGER, supra note 20, at 256-69, 274-75, 284.

24. See Missouri ex. rel. Gaines v. Canada, 305 U.S. 337, 350 (1938).

25. See Sweatt v. Painter, 339 U.S. 629 (1950).

26. See id. at 632-35. In a companion case, the Court held that the University of Oklahoma could not admit a Black man to its graduate program in education and then isolate him from other students in the classroom, library, and cafeteria. See McLaurin v. Oklahoma, 339 U.S. 637 (1950).

27. 347 U.S. 483 (1954).

28. Id. at 495 .

29. See id. at 494.

30. Green v. County Sch. Bd., 391 U.S. 430, 438 (1968); see also Brown v. Board of Educ., 349 U.S. 294, 301 (1955) (establishing the "all deliberate speed" formula); WILKINSON, supra note 20, at 61-102.

31. See Civil Rights Act of 1964, 78 Stat. 241 (codified at 28 U.S.C. $\S 1447,42$ U.S.C. $\S 1971$, 1975(a)-1975(d), 2000(a)-2000(h)(6)); WILKINSON, supra note 20, at 102-27. 
The push to integrate turned heavily on a corrective justice rationale. Federal courts, Congress, and civil rights agencies all sought to remedy the effects of past discrimination. ${ }^{32}$ Yet, the task of proving intentional exclusion of racial minorities on a case-by-case basis was a daunting one. Organizations like the NAACP had limited resources to pursue litigation that established a history of wrongful practices school by school. ${ }^{33}$ To facilitate integration, President Lyndon Johnson issued an executive order authorizing affirmative action, that is, voluntary plans to promote inclusion of racial minorities that did not rest on a finding of past discrimination. ${ }^{34}$ Under the aegis of affirmative action, federal education regulations and government advisories allowed public and private institutions of higher education to take special steps to ensure adequate representation of racial minorities in the student body, faculty, and staff. ${ }^{35}$

\section{B. Early Challenges to Affirmative Action}

As a result of these efforts, the proportion of non-White students in colleges and universities rose steadily in the late 1960 s and early 1970 s. $^{36}$ The growth of affirmative action soon prompted legal challenges to its constitutionality. In Defunis $v$. Odegaard, ${ }^{37}$ a White law school applicant denied admission to the University of Washington challenged its affirmative action prograin as a form of reverse discrimination. A Washington state trial court agreed with the plaintiff and ordered that he be admitted to law study. ${ }^{38}$ The Washington Supreme Court overturned the decision and upheld the affirmative action policy. ${ }^{39}$ When the plaintiff appealed, the United States Supreme Court dismissed the case as moot because the plaintiff had nearly completed law school. Four Justices dissented, urging that the Court immediately review the propriety of these admissions programs. $^{40}$

The next challenge came a few years later when Allan Bakke, a White medical school applicant, was denied admission to the University of

32. See, e.g., Owen M. Fiss, The Jurisprudence of Busing, 39 LAW \& CONTEMP. ProBs. 194, $194-99$ (1975); Paul Gewirtz, Choice in the Transition: School Desegregation and the Corrective Ideal, 86 CoLum. L. REv. 728, 731-54 (1986). For an effort to convert desegregation from a corrective for past discrimination into the solution to a fundamental political problem, see James S. Liebman, Desegregating Politics: "All-Out" School Desegregation Explained, 90 CoLUM. L. REV. 1463, 147374 (1990).

33. See Rachel F. Moran, Unrepresented, 55 Representations 139, 142 (1996).

34. See Exec. Order No. 11,246, 3 C.F.R. 339 (1964-1965).

35. See American Council on Education, Legal Developments Related to Affirmative ACTION IN HigHer Education 5-6 (1999).

36. See id. at 7-8.

37. 416 U.S. 312 (1974) (per curiam), vacating as moot 507 P.2d 1169 (1973), on remand, 529 P.2d 438 (1974).

38. See id. at 314 .

39. See id. at 315 .

40. See id. at 348, 350 (Brennan, J., dissenting) (joined by Douglas, White \& Marshall, JJ.). 
California at Davis. Bakke alleged that he would have been admitted but for the school's affirmative action program. Davis' program set aside a prescribed number of seats in the class for Blacks and Latinos, even though some had lower grade point averages and Medical College Admissions Test (MCAT) scores than White applicants who were denied admission. ${ }^{41}$ When the Supreme Court reviewed Bakke's claim that the admissions policy violated his right to non-discrimination under the Equal Protection Clause, the Justices were deeply divided. Four Justices were convinced that Davis could institute a color-conscious program of admissions so long as Congress recognized it as a legitimate means to address societal discrimination under Title VI of the Civil Rights Act. ${ }^{42}$ Another four Justices were equally insistent that absent a finding of past discrimination by University officials, Davis could not take race into account in its admissions process. ${ }^{43}$ As an institution receiving federal funds, it had to abide by a principle of colorblindness. In short, four Justices found affirmative action programs an appropriate way to build inclusive institutions, while four thought that the programs would inflict new injustices if not narrowly tailored to correct past wrongs.

Justice Lewis Powell carved out a middle way, and as the swing vote in the case, his opinion became highly influential. ${ }^{44}$ Skirting the question of corrective justice, Powell turned to pedagogical justifications for affirmative action. ${ }^{45}$ According to Powell, the First Amendment's guarantee of academic freedonı gave college and university administrators considerable discretion to structure the educational process as they saw fit. Whether or not an institution of higher education had engaged in past discrimination, it could select its student body in ways that enriched the learning process. Along with other personal traits, race and ethnicity could be considered to the extent that they correlated with perspectives that would otherwise be absent in the entering class. The resulting diverse student body would

41. In fact, the reasons for Bakke's denial of admission may have been more complex than his complaint suggested. Apparently, he was late in completing his application due to a family illness, and this delay substantially hurt his chances for admission. See BERNARd Schwartz, BEHIND Bakke: Affirmative Action AND the Supreme Court 5-6 (1988).

42. See Regents of the Univ. of Cal. v. Bakke, 438 U.S. 265, 324 (1978) (Brennan, J., concurring in part, dissenting in part) (joined by White, Marshall \& Blackmun, JJ.).

43. See id. at 408 (Stevens, J., concurring in part, dissenting in part) (joined by Burger, C.J., Stewart \& Rehnquist, JJ.).

44. See Michael Selmi, The Life of Bakke: An Affirmative Action Retrospective, 87 GEO. L.J. 981, 983 (1999) (asserting that Powell's opinion "has provided the controlling law on affirmative action in the educational context for most of the last twenty years").

45. For a general discussion of the objectives underlying affirmative action programs, see Paul Brest \& Miranda Oshige, Affirmative Action for Whom?, 47 STAN. L. REV. 855 (1995). In addition to corrective justice and pedagogical rationales, Brest and Oshige identify a distributive justice rationale. See id. at 867 . However, the reallocation of income and wealth has not figured prominently in legal justifications for affirmative action. 
contribute to an atmosphere of "speculation, experiment and creation" "46 through the robust exchange of ideas. Powell concluded that "it is not too much to say that the 'nation's future depends upon leaders trained through wide exposure' to the ideas and mores of students as diverse as this Nation of many peoples." 47 To illustrate this claim, Powell drew on the academic shortcomings of the segregated Texas law schools identified in Sweatt $v$. Painter:

The law school, the proving ground for legal learning and practice, cannot be effective in isolation from the individuals and institutions with which the law interacts. Few students and no one who has practiced law would choose to study in an academic vacuum, removed from the interplay of ideas and the exchange of views with which the law is concerned. ${ }^{48}$

To promote diversity, Powell allowed university administrators to accord a "plus" to race or ethnicity in the admissions process, but he prohibited them from using inflexible quotas except when there had been a finding of past discrimination by the institution. ${ }^{49}$ The flexibility of a plus accorded with the exercise of pedagogical discretion, while the quota was appropriate only as a judicial remedy to constrain the discretion of the untrustworthy.

\section{Current Challenges to Affirmative Action}

For twenty years, Powell's opinion offered a convenient basis for colleges and universities to defend their affirmative action programs. ${ }^{50}$ In the 1990s, however, the attacks on affirmative action in higher education intensified..$^{51}$ Once again, professional schools were at the center of the controversy. In 1990, the Office for Civil Rights (OCR) initiated a compliance review of Boalt's admissions practices and policies. ${ }^{52}$ OCR demanded that Boalt demonstrate that its affirmative action program was consistent with Powell's opinion in Bakke. In particular, the inquiry focused on

46. Bakke, 438 U.S. at 312 (quoting Sweezy v. New Hampshire, 354 U.S. 234, 236 (1957) (Frankfurter, J., concurring)).

47. Id. at 313 (quoting Keyishian v. Board of Regents, 385 U.S. 589, 603 (1967)).

48. Id. at 314 (quoting Sweatt v. Painter, 339 U.S. 629, 634 (1950)).

49. See id. at 315-20.

50. See Susan Welch \& John Gruhl, Does Bakke Matter? Affirmative Action and Minority Enrollment in Medical and Law Schools, 59 OHro ST. L.J. 697, 701-05, 714-17 (1998) (describing split in opinions and arguing that Bakke legitimated but did not fundamentally change affirmative action in higher education).

51. See Kathleen M. Sullivan, After Affirmative Action, 59 Oнго ST. L.J. 1039, 1040 (1998) (noting that "Bakke's compromise is . . . caught in a pincer movement of political and constitutional change").

52. See Letter from Gary D. Jackson, Regional Civil Rights Director, U.S. Department of Education, Office for Civil Rights, Region X, to Dr. Chang-Lin Tien, Chancellor, University of California at Berkeley, Re: University of California at Berkeley School of Law, Case No. 10906001 (Sept. 25, 1992) (on file with author). 
whether race and ethnicity were treated differently than other forms of diversity and, if so, why. OCR also wanted to know how Boalt's targets related to its pedagogical objectives.

In a 1993 report, ${ }^{53}$ Boalt addressed these questions to the federal agency's satisfaction. After reviewing the history and operation of the admissions program, the law school noted that race and ethnicity were treated differently from other traits only insofar as the desired level of diversity would not occur naturally. Once a satisfactory amount of diversity could be achieved without special attention to race or ethnicity, these characteristics were treated like any other. For example, certain Asian-American subgroups no longer received a plus because they were adequately represented without one. ${ }^{54}$

As for the enrollment targets for Blacks and Latinos, these were linked to a notion of "critical mass." Asserting that "[t]okenism is the enemy of diversity," 55 the law school's report relied on social science evidence showing that when people of color attended colleges and universities in very small numbers, their achievement was depressed and they often became alienated and isolated from the rest of the student body. Once a critical mass of ten percent was achieved, these students' academic performance improved, and they were better able to bring the qualities of voice and perspective that Bakke endorsed. ${ }^{56}$ The report also noted that the concept of critical mass was linked to perceptions of proportionality; for example, women might feel underrepresented, even if they accounted for ten percent of the class, because they made up fifty percent of the general population. $^{57}$

Boalt's report successfully drew on Powell's pedagogical rationale to defend the law school's affirmative action program. Relying on existing research and Boalt's own experience, the law school asserted that its admissions goals were necessary to achieve the robust exchange of ideas that Powell prized. A few years later, however, a federal court of appeals in Texas rejected the diversity rationale outright. In Hopwood $v$. Texas,${ }^{58}$ four White law school applicants were denied admission to the University of Texas. They sued, alleging that the law school's admissions process operated as "the functional equivalent of an impermissible quota system in which the law school attempts to camouflage quotas through the use of the

53. See Statement of Faculty Policy Governing Admission to Boalt Hall and Report of the Admissions Policy Task Force (1993) (on file with author).

54. See id. at 14.

55. Id. at 24 .

56. See id. at $26-28$.

57. See id. at 28-31. The report further noted that even with speeial consideration, it was not possible to achieve critical mass for some severely disadvantagcd groups, such as Native Americans. See id. at 30-31.

58. 861 F. Supp. 551 (W.D. Tex. 1994), rev'd and remanded in part, 78 F.3d 932 (5th Cir. 1996), cert. denied, 518 U.S. 1033 (1996), on remand, 999 F. Supp. 872 (W.D. Tex. 1998). 
term 'goals."'59 The law school relied heavily on an index that was based on an applicant's grade point average and LSAT score. The admissions committee employed two cutoffs: one for students with high index scores who were presumptively admitted and one for students with low scores who were presumptively denied admission. When an applicant's score fell between the cutoffs, the committee made discretionary judgments about admission based not only on the index score but also the candidate's overall qualifications. ${ }^{60}$ The law school's admission process made significant racial distinctions. First, it employed higher cutoffs for Whites than for Blacks and Latinos. Moreover, when White applicants' scores fell between the cutoffs, their files were reviewed by the committee but the number of candidates who could be admitted was capped. By contrast, there was no cap on the number of Black and Latino applicants who could be admitted from this range. ${ }^{61}$

In federal district court, Judge Sam Sparks concluded that the law school could use a program of affirmative action, but it could not use separate procedures to admit Blacks and Latinos. The admissions program at Texas did not conform to Powell's dictates that individuals be compared with other individuals, some of whom would receive a plus based on race or ethnicity, while others received pluses on other grounds, such as place of residence or economic hardship. According to Sparks:

The constitutional infirmity of the 1992 law school admissions procedure ... is not that it gives preferential treatment on the basis of race but that it fails to afford each individual applicant a comparison with the entire pool of applicants, not just those of the applicant's own race. ${ }^{62}$

Although Sparks considered the continued need for affirmative action "regrettable,"63 he believed that carefully tailored programs were constitutional to "overcome the effects of years of discrimination and to serve important societal goals." 64

On appeal, the Fifth Circuit rejected not only Sparks' view that affirmative action was necessary to do corrective justice but also Powell's assertion that affirmative action improved the educational climate. Because the law school had remedied the effects of past intentional discriminatory practices that ended in the 1960 s, it no longer had an obligation to

59. 861 F. Supp. at 574.

60. See id. at $560-61$.

61. See id. at $562 \& \mathrm{nn} .27-29$ (committee members had a limited number of files to review and votes to cast for nonminority candidates in the discretionary range but could evaluate and make decisions about as many minority candidates as they felt comfortable reviewing).

62. Hopwood, 861 F. Supp. at 579.

63. Id. at 583.

64. Id. at 584 . The court further found that there were legitimate, nondiscriminatory reasons for denying the plaintiffs admission to the class, so they were awarded nominal damages of one dollar each and given the opportunity to reapply to the law school free of charge. See id. at 582-83. 
compensate for these injustices through affirmative action. Moreover, the law school could not use the program to account for ongoing societal discrimination for which the law school was not directly responsible. ${ }^{65}$ As for Powell's opinion, the Fifth Circuit dismissed it as a discredited jurisprudence of equal protection, reasoning that Powell wrote only for himself and that the United States Supreme Court had since repudiated diversity as a basis for race-based preferences. In the Fifth Circuit's view, Powell had invoked stereotypical notions that students' race or ethnicity could predict their viewpoints, and his diversity rationale therefore stigmatized students and exacerbated racial tensions. ${ }^{66}$ The court of appeals concluded that corrective justice was the only viable rationale for affirmative action programs, and it did not apply in the Hopwood case. ${ }^{67}$

Since Hopwood, White applicants who were denied admission have sued the University of Michigan Law School, alleging that its affirmative action program also violates equal protection. ${ }^{68}$ Unlike the University of Texas, the University of Michigan has never been found guilty of intentional discrimination, nor do its recent practices provide a basis for inferring racial animus against non-Whites. On the contrary, rejected White applicants have accused admissions officials of being overly generous to previously underrepresented groups. Under the circumstances, then, Michigan's most promising basis for defending its program is Powell's pedagogical rationale, and University counsel have introduced a wide range of expert testiniony on the benefits that diversity affords in higher education. ${ }^{69}$ Whether this testimony will convince the federal courts that the Michigan program is constitutional remains to be seen. However, what seems clear is that the litigation has highlighted the limited social science evidence available and spurred new interest in studying the inipact of diversity on the learning process.

65. See Hopwood, 78 F.3d at 948-55.

66. See id. at 945-46. A federal district court judge expressed similar doubts about the diversity rationale but refused to strike down a university's affirmative action program because the White male plaintiff failed to show that but for the program, he would have bcen admitted. As a result, he lacked standing to lodge a constitutional challenge. See Tracy v. Board of Regents, 59 F. Supp. 1314 (S.D. Ga. 1999).

67. See Hopwood, 78 F.3d at 944.

68. See Grutter v. Bollinger, Civ. Action No. 97-75231 (E.D. Mich). A lawsuit is also pending on behalf of White applicants who were denied admission to the undergraduate program at the University of Michigan. See Gratz v. Bollinger, Civ. Action No. $97-75928$ (E.D. Mich).

69. See The Compelling Need for Diversity in Higher Education (visited on May 26, 1999) <http://www.umich.edu/ newsinfo/Admission/Expert.html> (reproducing testimony of nine experts on the continued racial and educational segregation experienced by students before they attend the university, the need to encounter racial and ethnic diversity in their college and university life, and the benefits of diversity for their educational experience). 
II.

\section{Social Science Evidence on Diversity and the Learning Process}

Despite the extensive testimony amassed by counsel for the University of Michigan, existing studies are both limited in number and modest in scope, with most research thus far focusing on the impact of desegregation in kindergarten through high school. While studies of public elementary and secondary school students have focused on whether desegregation improves student achievement and racial attitudes, most research on college and university campuses has eschewed attempts to measure the impact of diversity on student achievement and instead focused on student attitudes and institutional commitments. ${ }^{70}$

Some research seeks to quantify uniform measures of success for affirmative action programs, typically by adıministering surveys or paperand-pencil tests that operationalize key variables like achievement and attitudes. The quantitative studies measure student accomplishments during and after graduation as well as student attitudes. This research generally assumes that non-White students should adapt to predominantly White colleges and universities, as demonstrated by comparable academic performance. In addition, it presumes that both White and non-White students will gain tolerance and understanding through interracial contact. Because this work focuses on students' adaptability, it says little about institutional change in response to diversity. At most, college and university administrators are expected to manage the conflicts that arise during the transition from racially hoinogeneous to racially heterogeneous institutions. By contrast, qualitative studies have relied on interviews and focus groups to generate new insights into students' experiences with and perceptions of diversity. This work evaluates not only how satisfied and successful students are but also how well colleges and universities have adapted to the racial and ethnic transformation of their student bodies. Qualitative researchers treat the outcomes of affirmative action as particular and contingent, the product of complex interactions between student bodies and the institutions they inhabit.

\section{A. Student Achievement During School}

The small body of work on student achievement has addressed whether diversity affects the performance of minority students at predominantly White campuses. Building on Rosabeth Moss Kanter's work on

70. See Maureen T. Hallinan, Diversity Effects on Student Outcomes: Social Science Evidence, 59 OHi ST. L.J. 733, 740-53 (1998) (summarizing empirical studies on the impact of diversity on student achievement, aspirations, attitudes, and behavior). 
tokenism, ${ }^{71}$ this research examines whether token status has an adverse impact on student performance. ${ }^{72}$ Kanter defines a token as a person:

[T]dentified by ascribed characteristics (master statuses such as sex, race, religion, ethnic group, age, etc.) or other characteristics that carry with them a set of assumptions about culture, status, and behavior highly salient for majority category members. They bring these "auxiliary traits"... into situations in which they differ from other people not in their ability to do a task or in acceptance of work norms but only in terms of these secondary and informal assumptions. ${ }^{73}$

Kanter goes on to note that:

[B]ecause tokens are by definition alone or virtually alone, they are in the position of representing their ascribed category to the group, whether they choose to do so or not. They can never be just another member while their category is so rare; they will always be a hyphenated member, as in "woman-engineer" or "male-nurse" or "black-physician."74

Kanter posits that the difficulties tokens face intensify if majority group members are used to dealing with others who have the token trait in settings with distinctive power and status relationships. For example, men may be used to dealing with women at home rather than at work, or Whites may be accustomed to having non-Whites perform menial rather than professional tasks. ${ }^{75}$ Kanter theorizes that tokens will be especially burdened to the extent that their ascribed trait is readily visible and new to the environment. As a result, it would be harder to be the first and only Black on the job than to have a hidden learning disability in a workplace with a long history of accommodating people with disabilities. ${ }^{76}$

Kanter predicts that tokenism will increase stress on the lone or few menibers who have the relevant trait because they come under greater scrutiny than menibers of the majority group. Faced with dangers of polarization and stereotyping, tokens face unique performance pressures. According to Kanter, tokens are likely to respond in one of two ways: some become overachievers, putting in extra effort and striving to advance at every opportunity, while others limit their visibility by keeping a low

71. See Rosabeth Moss Kanter, Some Effects of Proportions on Group Life: Skewed Sex Ratios and Responses to Token Women, 82 AM. J. Soc. 965 (1977).

72. See Mitchell James Chang, Racial Diversity in Higher Education: Does a Racially Mixed Student Population Affect Educational Outcomes? 34-35 (1996) (unpublished Ph.D. dissertation, University of California, Los Angeles) (on file with the University of California, Los Angeles Library) (describing studies that have built on Kanter's work on proportionality).

73. Kanter, supra note 71, at 968.

74. Id.

75. See id.

76. See id. at 969. 
profile, avoiding social contacts, and minimizing conflicts and risks. ${ }^{77}$ Members of the majority group, on the other hand, can be expected to take steps to exaggerate differences, isolate tokens, or demand displays of loyalty from them in return for inclusion. ${ }^{78}$

Subsequent empirical research has demonstrated the harmful effects of token status. ${ }^{79}$ However, once a threshold number of previously underrepresented students is reached, studies do not demonstrate any umiform improvement in achievement due to further increases in representation. ${ }^{80}$ Researchers have suggested that with rising numbers of people of color, racial tensions can increase with detrimental consequences for minority students. If institutions fail to address the impact of diversity, group conflict can make for a chilly campus climate. ${ }^{81}$ The challenges of achieving the critical mass that avoids the harms of tokenism without succumbing to the balkanization that accompanies increased racial diversity could explain why integration does not always lead to improved academic performance. For example, a longitudinal study of Black students at predominantly White colleges and historically Black colleges did not find that Black student achievement improved through participation in an integrated institution. ${ }^{82}$ To maximize the benefits of diversity, reformers have urged university administrators to encourage interracial contact inside and outside the classroom. Cooperative learning activities, faculty-student contact, and multicultural centers offer opportunities to create a positive racial climate on campus. ${ }^{83}$

\section{B. Student Achievement After Graduation}

In recent years, a new body of work has emerged that emphasizes accomplishments after graduation to defend affirmative action programs. This research acknowledges a persistent gap in academic credentials at the

77. See id. at $971-75$.

78. See id. at $975-80$.

79. See, e.g., George Eaton Simpson \& J. Milton Yinger, Racial and Cultural Minorities: AN ANALYsis of Prejudice aNd Discrimination (5th ed. 1985); Eve Spangler et al,, Token Women: An Empirical Test of Kanter's Hypothesis, 84 AM. J. Soc. 160 (1978); Linda Sax, The Dynamics of "Tokenism": How College Students Are Affected by the Proportion of Wornen in Their Major (1994) (unpublished Ph.D. dissertation, University of California, Los Angeles) (on file with the University of California, Los Angeles Library).

80. See Chang, supra note 72 , at 30-53 (collecting and reviewing studies).

81. See Hubert M. Blalock, JR., TOWARd a Theory of Minority-Group Relations (1967); Sylvia Hurtado, The Campus Racial Climates: Contexts of Conflicts, 63 J. HIGHeR Educ. 539 (1992); C.T. Mohanty, On Race and Voice: Challenges for Liberal Education in the 1990s, in BETWEEN Borders: Pedagogy and the Politics of Cultural Studies 145 (Henry A. Giroux \& Peter McLaren eds., 1994).

82. See Ernest T. Pascarella et al., Influences on Students' Openness to Diversity and Challenge in the First Year of College, $67 \mathrm{~J}$. HrGHeR EDuc. 174 (1996).

83. See Sylvia Hurtado et al., Enhancing Campus Climates for Racial/Ethnic Diversity: Educational Policy and Practice, 21 Rev. HIGHER EDuc. 279, 294-95 (1998). 
college and university level. Rather than focus on the educational experience at the heart of Powell's pedagogical rationale, these studies analyze the general contributions to society that beneficiaries of affirmative action make after they graduate. This shift to evaluating post-graduate performance may signal some doubts about the continuing validity of Powell's opinion.

Perhaps the most prominent example of this approach is the widely heralded book by former university presidents William G. Bowen and Derek Bok. ${ }^{84}$ Bowen and Bok conducted a large-scale survey of students at twenty-eight institutions with high selectivity in their admissions processes, ${ }^{85}$ asking students about their education, work history, and civic activities. $^{86}$ The survey identified students from three generational cohorts: those entering colleges and universities in the fall of 1951, 1976, and $1989 .{ }^{87}$ The 1951 cohort provided a baseline reference point for the period before affirmative action became commonplace in higher education. The 1976 cohort enrolled when institutions were making determined efforts to diversify their student bodies. The 1989 cohort was the most recently graduated group that the researchers could study. ${ }^{88}$

Bowen and Bok's book documents an achievement gap at the college and university level. Black students in the 1989 cohort had the lowest graduation rates, while Asian-American students had the highest rates. Latino rates were higher than those for Blacks but lower than those for Whites and Asian Americans. This pattern was similar for undergraduate and professional schools. ${ }^{89}$.The authors also found a grade gap among White, Black, and Latino students. The average rank of matriculants was at

84. See William G. Bowen \& Derek BoK, The Shape of the River: Long-Term Consequences of Constdering Race in College and University Admissions (1998).

85. See id. at 291-94. The study included four public universities, thirteen private universities, seven coeducational liberal arts colleges, and four women's colleges. See id. at 292-93.

86. See id. at 300-01. For the 1989 eohort only, the survey ineluded questions about interactions with students from different backgrounds both during and after college. See id. at 315-35.

87. The survey included 20,662 respondents from the 1976 cohort (a $69.6 \%$ response rate for the entire group of students and a 79.9\% response rate for those who could actually be loeated) and 9,549 students from the 1989 cohort (a 76.3\% response rate for the entirc group and an $84 \%$ response rate for those who could be located). After the survey was completed, the researchers asked a sample of Black and White members of the 1976 and 1989 cohorts to participate in follow-up interviews. Letters were sent only to respondents who had returned a card indicating their willingness to be interviewed, and the interviews were "free-flowing rather than structured." Id. at 301. As a result, the approximately sixtyfive interviews were not included in the scientific analysis, although some comments from the conversations were included in the text when deened appropriate. See id. at 301-03.

88. See id. at 293.

89. See id. at 55-57. High SAT scores, matriculation at a selective college, and high socioeconomic status correlated positively with graduation rates. For Blacks, attendance at a selective institution and socioeconomic background were particularly powerful predictors of successful coinpletion of college or professional school. See id. at 59-68. Graduation rates improved for all students between 1976 and 1989. See id. at 68-69. 
the twenty-third percentile for Blacks, the thirty-sixth percentile for Latinos, and the fifty-third percentile for Whites. ${ }^{90}$

This performance gap did not seem to hamper academic aspirations. Focusing on Black and White students, Bowen and Bok found that "Black college students have a remarkably strong interest in advanced training. Nationally, 63\% of all African Americans who entered four-year colleges in 1989-90 aspired to earn an advanced degree of some kind, compared with $61 \%$ of white students." 91 Professional school was particularly attractive, with $35 \%$ of Black matriculants, but only $22 \%$ of White matriculants, aspiring to a degree im law or medicine..$^{92}$ The pattern was comparable for the 1976 cohort. ${ }^{93}$ In fact, both Black and White graduates earned advanced degrees in high and remarkably similar numbers. For example, in the 1976 cohort, $40 \%$ of all Black and $37 \%$ of all White graduates obtained professional or doctoral degrees. ${ }^{94}$ Blacks were more likely than Whites to earn a medical or law degree, while Whites were more likely than Blacks to obtain a doctorate..$^{95}$

Bowen and Bok found that, after graduation, Black and White men in the 1976 cohort had similar rates of employment, while Black women were substantially more likely to be employed than White women. ${ }^{96}$ Although einployment rates were comparable, wage gaps based on race and gender persisted. ${ }^{97}$ In general, students in the 1976 cohort had high rates of civic participation. Even so, Black men were more likely than White men to engage in community service. Black women were less likely than White women to be involved in these activities, but when only women participating full-time in the work force were studied, Black females gave more of their time than White females. ${ }^{98}$ Based on these findings, Bowen and Bok conclude that despite persistent gaps in academic performance between Whites and non-Whites, affirmative action programs have enabled

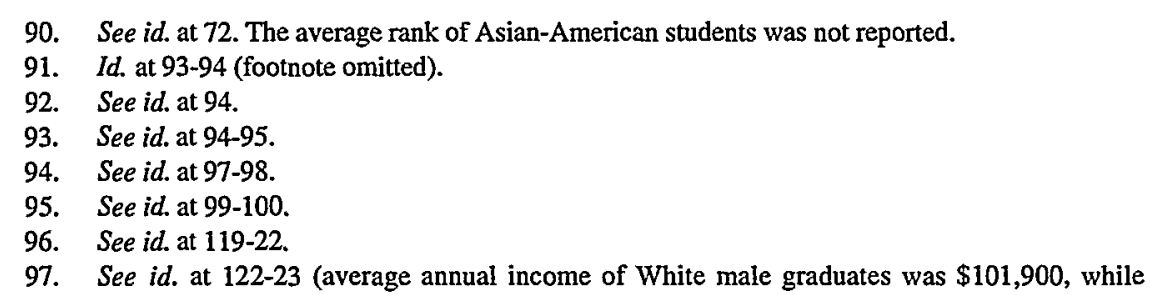
Black male graduates earned $\$ 85,000$; White female graduates on average brought home $\$ 66,000$, while Black female graduates received $\$ 64,700$ ). Graduating from a selective institution helped narrow the wage gap betwecn Black and White males, while the gap between Black and White females was almost completely eliminated. However, the gender gap within each race remained substantial. See id. at 122-25. About sixty percent of the racial gap in earnings for men and the entire gap for women disappeared when differences in SAT scores, grades, chosen fields of study, socioeconomic status, and selectivity of institution attended were taken into account. See id. at 145.

98. See id. at $157-60$. 
non-Whites to obtain substantial levels of education, successfully enter the work force, and contribute to their communities. ${ }^{99}$

In a study focusing on University of Michigan law school graduates, David Chambers, Richard Lempert, and Terry Adams found that although LSAT scores and undergraduate grade-point averages correlated strongly with law school grades, they had no relationship to achievement after law school as measured by earned income, career satisfaction, or service to the profession and community. ${ }^{100}$ According to the authors, "[f]or both our minority and white alumni those numbers that counted so much at the admissions stage tell little if anything about their later careers." ${ }^{101}$ The study found that almost all graduates, whether White or non-White, had passed the bar examination and earned entry into the profession. ${ }^{102}$ Once in the profession, private practice dominated career choices, although Whites were more likely than non-Whites to enter private practice, particularly in large firms. ${ }^{103}$ Non-Whites were more likely than Whites to work for the government. The proportions of White and non-White graduates entering the public interest sector was very small, regardless of race. ${ }^{104}$ With the exception of those who graduated in the 1990s, Whites earned higher median incomes than non-Whites, primarily because more Whites than non-Whites were in private practice. ${ }^{105}$ Non-Whites tended to earn higher

99. See id. at 256-58 (focusing on Black achievement).

100. See David L. Chambers et al., Doing Well and Doing Good: The Careers of Minority and White Graduates of the University of Michigan Law School, 1970-1996, LAw QuADRANGLe Notes, Summer 1999, at 60, 61; Richard O. Lempert, et al., Michigan's Minority Graduates in Practice: A River Runs through Law School, 25 LAw \& Soc. INQUIRY 395, 401-02 (2000). The authors mailed a survey in the spring of 1998 to 2,196 alumni of the University of Michigan's program between 1970 and 1996. Graduates were broken down into three categories: those who graduated in the 1970s, the 1980s, and the 1990s. See Chambers et al., supra, at 61; but see Lempert et al., supra, at 402 (reporting that 2,204 questionnaires were mailed, but only 2,144 were used in the data analysis). Of those surveyed, 755 were Black, 300 Latino, 60 Native Ámerican, 154 Asian, and 927 White. The response rate was $51.4 \%$ for minority alumni and $61.9 \%$ for White alumni. See Chambers et al., supra at 62 . Because most Asian graduates had finished school in the $1990 \mathrm{~s}$, the authors focused on White graduates on the one hand and Black, Latino, and Native American graduates on the other. See id., at 61; Lempert et al., supra, at 403.

101. Lempert et al., supra note 100 , at 422 . But cf. Chambers et al., supra note 100 , at 71 (warning against overinterpreting the findings, given the fact that "[t]he Michigan students who are admitted, minority and white, fall within a narrow band of skills and performance, a band of high achievement").

102. See Chambers et al., supra note 100, at 63; Lempert et al., supra note 100, at 422.

103. See Chambers et al., supra note 100, at 63-66 (stating that non-White graduates in the 1970s were less likely to enter private practice than White graduates, while in the 1980s and 1990s, nonWhite graduates were less likely than White graduates to enter large firms).

104. See Chambers et al., supra note 100, at 64 tbl.2; Lempert et al., supra note 100, at 427-30.

105. See Chambers et a1., supra note 100, at 65-66; Lempert et al., supra note 100 , at 453 (concluding that, in private practice, differences in salaries of White and minority alumni are not statistically significant once gender and years since graduation are controlled for). 
wages than Whites in government. ${ }^{106}$ All of the graduates expressed high degrees of career satisfaction, regardless of race. ${ }^{107}$

Like Bowen and Bok, the Michigan researchers found that non-White graduates more often engaged in unremunerated service activities, such as mentoring young lawyers, serving on the board of a non-profit corporation, doing political work, or performing pro bono legal work. ${ }^{108}$ Black and Latino graduates also were substantially more likely to serve Black and Latino clients and organizations than were White graduates. ${ }^{109}$ Based on these findings, the authors conclude, much like Bowen and Bok, that:

[I]n addition to the values that the ethnic diversity of our students have contributed to the Law School environment, our minority graduates, like our white graduates have gone on to make significant achievements in the profession.... Michigan Law School's admissions program has brought into the profession large numbers of minority lawyers who have become financially successful, happy with their careers, and generous with their time through community service. ${ }^{110}$

\section{Student Attitudes}

In addition to looking at achievement during school and after graduation, a considerable amount of research has been devoted to evaluating the relationship between diversity and student attitudes. This work consistently demonstrates that exposure to a diverse student body leads to beneficial changes in racial outlook, particularly among students who arrive with an openness to interracial exchange. ${ }^{111}$ Students at a racially and ethnically diverse campus become more receptive to interacting across racial and ethnic lines than those who go to a homogeneous campus, and students at diverse campuses report greater satisfaction with their college experience than those at campuses that are not diverse. ${ }^{112}$ White students in particular benefit from the growing presence of minority groups through increased interracial contacts, heiglitened racial and ethnic awareness, and improved communication with members of other racial and ethnic groups. ${ }^{113}$ Students

106. See Chambers et al., supra note 100, at 66 tbl.4; see also Lempert et al., supra note 100, at 453 (concluding that differences in income of White and minority alumni in government who graduated in the 1970 s are marginally significant).

107. See Chambers et al., supra note 100, at 66 tbl.3; Lempert et al., supra note 100, at 445 (noting that the only significant differences related to greater satisfaction for Whites than minorities in business).

108. See Chambers et al., supra note 100, at 69 tbl.5; Lempert et al., supra note 100, at 453-57.

109. See Chambers et al., supra note 100, at 69 tbl.6; Lempert et al., supra note 100, at 439-40.

110. Chambers et al., supra note 100, at 71.

111. See Ernest T. Pascarella et al., What Have We Learned from the First Year of the National Study of Student Learning?, 37 J. C. STUDENT DEv. 182, 188 (1996).

112. See Alexander W. Astin, Diversity and Multiculturalism on the Campus: How Are Students Affected?, 25 Change 44, 48 (1993).

113. See, e.g., Hallinan, supra note 70, at 750; Pascarella, supra note 82, at 192. 
of color at predominantly White universities necessarily deal with students from other racial and ethnic groups, but the opportunities for White students to interact with members of other groups expand as the representation of non-Whites grows. ${ }^{114}$ The benefits of diversity can be enhanced by structuring opportunities to evaluate racial and ethnic issues and to have interracial contact. For example, several studies have demonstrated that courses on multiculturalism and race relations can have a positive impact on racial attitudes. ${ }^{115}$

Taken together with the work on tokenism and academic achievement, these findings pose an interesting paradox. When the proportion of racial and ethnic minorities increases at a campus, the salience of racial and ethnic difference grows. The resulting sense of balkanization may harm the academic performance of students of color by making them feel isolated or at odds with the university's commitment to cosmopolitanism. ${ }^{116}$ This perceived divisiveness, though, does not reduce opportunities for interracial contact, particularly for White students, who gain increased tolerance and understanding. A recent study by Anthony Lusius Antonio sheds some light on this seeming contradiction between perceptions of racial division and the realities of everyday interracial relationships. ${ }^{117}$ Antonio found that while $90 \%$ of students believed that there was racial balkanization on campus, over half had racially diverse friendship groups. ${ }^{118}$ That is, many students reported that relationships on campus were racially segregated, while they themselves enjoyed the benefits of interracial contact. Students with the most diverse contacts tended to meet their friends in residence halls and to come from diverse pre-college

114. Anthony Lusius Antonio, The Impact of Fricndship Groups in a Multicultural Univcrsity 1437 (1998) (unpublished Ph.D. dissertation, University of California, Los Angeles) (on file with the University of California, Los Angeles Library) (reviewing and discussing literature).

115. See, e.g., Maurianne Adams \& Yuhui Zhou-McGovern, The Sociomoral Development of Undergraduates in a "Social Diversity" Course: Developmental Theory, Research and Instructional Applications (1994) (unpublished manuscript, available in ERIC, No. ED380345); Thomas R. Biddell et al., Developing Conceptions of Racism Among Young White Adults in the Context of Cultural Diversity Coursework (1994) (unpublished manuscript, available in ERIC, No. ED377270); Octavio Villalpando, Comparing the Effects of Multiculturalism and Diversity on Minority and White Studcnts' Satisfaction with College 15-16 (1994) (unpublished manuscript, available in ERIC, No. ED375721).

116. See Chalsa M. Loo \& Gary Rolison, Alienation of Ethnic Minority Students at a Predominantly White Univeristy, 57 J. HIGHER EDUc. 58, 71-73 (1986) (noting that ethnic minority students expressed their alienation through feelings of cultural domination and isolation and had views about the role of ethnic organizations that differed from those of White classmates).

117. See Antonio, supra note 114. Based on information forms filled out by UCLA undergraduates, Antonio sent questionnaires about friendship patterns to 2,222 students and received 677 responses. Response rates differed sharply for men (twenty-five pcrcent) and women (thirty-fivc percent), so that sixty-three percent of the sample was female. See id. at 49-50, 82-83. The author followed up on the survey results by conducting interviews with eighteen men, representing all racial and ethnic groups sampled. See id. at 50-51.

118. See id. at 133. 
environments. ${ }^{119}$ Students with racially and ethnically diverse friends reported more interracial interaction outside their immediate circle as well. Frequent interaction across racial and ethnic lines was associated with increased commitment to racial understanding and gains in cultural awareness. ${ }^{120}$ However, diverse friendships were described as less emotionally intimate than same-race friendships, suggesting that differences in background still had some inhibiting effect on candor and trust. ${ }^{121}$

Based on follow-up interviews, Antonio concluded that widely shared perceptions of balkanization stemmed in part from the presence of racial and ethnic organizations on campus. Though stiginatized as divisive, these organizations and activities offered a critical source of comfort and support as students of color adjusted to canipus life. This support was particularly critical for Black students, who were more likely than Latino or Asian-American students to use these organizations as a source of racially homogeneous friendships. In light of their small numbers on campus, Blacks may have relied on same-race friendships to buffer themselves from an environment that they perceived as overwhelmingly White and uninviting. ${ }^{122}$ Most students of color, however, saw no contradiction between developing friendships through the organizations and engaging in a wide array of interracial interactions. Nevertheless, other students' negative views of race- and ethnic-specific commitments could have interfered with minority students' ability to use the organizations to mediate their college or university experience. ${ }^{123}$

At least one study has focused specifically on attitudes toward diversity in a law school setting. ${ }^{124}$ The survey, conducted by Gary Orfield and Dean Whitla, found that approximately $40 \%$ of students at Harvard's and Michigan's law schools had little or no contact with members of different racial or ethnic groups while growing up or in high school. ${ }^{125}$ Higher education significantly broadened the students' exposure to people from different backgrounds: only $20 \%$ reported such limited interracial contact

119. See id. at $179,187$.

120. See id. at 133-34.

121. See id. at 133, 176 .

122. See id. at $177-78,199$.

123. See id. at 161 (noting that "[s]tudents with diverse friendship groups also shared a negative attitude toward ethnic cliques").

124. See Gary Orfield \& Dean Whitla, Diversity and Legal Education: Student Experiences in Leading Law Schools (visited Sept. 17, 1999) <http://www.law.harvard.edu/groups/civilrights/ publications/lawsurvey.html $>$. After conducting pilot surveys of students at elite law schools by e-mail and through the Internet in 1998, the authors worked with the Gallup organization to perform a survey of students at Harvard and Michigan law schools that would yield high response rates. A total of 1,820 students were surveyed with a remarkable $81 \%$ response rate. See id. at 8-9. Of those who responded, $66.9 \%$ were White, $6.7 \%$ were Black, $4.3 \%$ were Hispanic, $.6 \%$ were Native American, and $7.6 \%$ were foreign. See id. at 10 tbl.1.

125. See id. at 9-10 tbls.2-3. 
in college. ${ }^{126}$ Over $90 \%$ of Whites reported having three or more friends from a different racial or ethnic background, while slightly over $50 \%$ of the Asian-American students, $37 \%$ of Black students, and $30 \%$ of Latino students reported this level of interracial friendship. ${ }^{127}$ Consistent with other research findings, students who doubted the academic benefits of interracial classes nevertheless believed that "in the dorms, living with folks of different races has been overwhelmingly positive." 128

At law school, only about $16 \%$ of students stated that they had little or no contact with persons of other races and ethnicities, but nearly $40 \%$ stated that they rarely or never studied with people from different racial or ethnic backgrounds. ${ }^{129}$ Over two-thirds of the students believed that diversity enhanced their educational experience both inside and outside the classroom, while only about $5 \%$ thought it detracted ${ }^{130}$ A staggering $90 \%$ of students were committed to the proposition that "having students of different races and ethnicities" qualified as a positive aspect of their educational experience. ${ }^{131}$ As for whether conflicts among students reinforced racial stereotypes, only about $17 \%$ of students reported that they did, while over $80 \%$ believed that racial differences challenged them to rethink their values. ${ }^{132}$

Most students thought that racial differences could be converted into positive learning experiences. In particular, about $80 \%$ reported that discussions with students from different racial or ethnic backgrounds had changed their beliefs about the criminal justice system, conflicts over individual rights, social and economic institutions, and civil rights. ${ }^{133}$ Seventy percent stated that these discussions changed their views of "the kind of legal or community issues that you will encounter as a professional." 134 Despite these reported changes in thinking, just $34.4 \%$ found racially diverse classes nore intellectually challenging than homogeneous ones. ${ }^{135} \mathrm{At}$ the same time, though, $47.3 \%$ believed that diverse classes offer "more serious discussions of alternative perspectives" than homogeneous classes, and $44.3 \%$ thought that they cover "a greater variety of subjects and

126. See id. at 10 tbl.4.

127. See id. at 11-12 tbl.5.

128. Id. at 11.

129. See id. at 12-13 tbls.6-7.

130. See id. at $14-17$ tbls. $8-11$.

131. Id. at 15-16 tbl.12 (seventy percent calling it "clearly positive" and twenty percent calling it "moderately positive"). By contrast, a lower proportion of alumni of Michigan's law school reported plaeing considerable value on ethnic diversity in their classroom experience, though the proportions increased from the 1970s to the 1990s. Lempert et al., supra note 100, at 413-18.

132. See Orfield \& Whitla, supra note 124, at 16-17 tbls.13-14.

133. See id. at 17-21 tbls.15-18, 20.

134. Id. at 20 tbl.19.

135. See id. at $21-22$ tbl.21. Of the respondents, $36.8 \%$ thought there was no difference, $25.6 \%$ could not answer, and 3.4\% thought homogeneous classes were more challenging than diverse ones. See id. 
examples" than homogeneous ones. ${ }^{136}$ Consistent with their views about the positive impact of diversity, $80 \%$ of students would strengthen or maintain current affirmative action policies. ${ }^{137}$

While Orfield and Whitla's study provides some insight into law students' beliefs about diversity, the findings do not indicate why students reached these conclusions. Given the format of the survey, students did not have the opportunity to offer specific instances in which diversity changed their educational experience, nor did the study explore how classes, extracurricular activities, and social life affect the role of diversity in a student's life. Because the results were reported in aggregate, statistical form, it is not possible to determine how individual traits, sucli as race and ethnicity, gender, and openness to interracial contact, affect a student's views about diversity. In short, this research provides bottom line appraisals without offering much sense of the institutional and mdividual variables that shape the students' judgnients.

\section{Qualitative Studies Based On Interviews and Focus Groups}

Much of the research linking diversity to achieventent and attitude has relied on surveys distributed to large numbers of students, either on a single occasion or longitudinally. Typically, these studies focus on diversity's impact on individual students without questioning institutional commitments very closely. A somewhat different body of research has relied on focus groups and in-depth interviews to describe how institutional structures and assumptions influence experiences with diversity. Because interviews are labor intensive and generally yield qualitative rather than quantitative data, the studies are few in number. Still, the results offer sonue intriguing, albeit preliminary, insights into how the very nature of the educational process limits diversity's mipact on the exchange of ideas.

A study by Eric Margolis and Mary Romero addresses how the process of professionalization has marginalized and excluded traditionally underrepresented groups, particularly women of color, in graduate study. ${ }^{138}$

136. Id. About half of the students reported that there was no difference or they could not answer, while only $3.2 \%$ thought homogenous classes offered a greater range of perspectives than diverse ones and $2.2 \%$ reported that they covered more subjects and examples in homogeneous than diverse classes. See id.

137. See id. at 22-23 tbl.22. Two recent surveys found that university faculty in general and law faculty in particular, express high levels of support for diversity and affirmative action as well. See American Council on Education and American Association of University Professors, Does Diversity Make a Difference? Three Research Studies on Diversity in College Classrooms (2000) (on file with author); Richard A. White, Preliminary Report: Law School Faculty Views on Diversity in the Classroom and the Law School Community (May 2000) (on file with author).

138. See Eric Margolis \& Mary Romero, "The Department Is Very Male, Very White, Very Old, and Very Conservative": The Functioning of the Hidden Curriculum in Graduate Sociology Departments, 68 HARv. EDUC. REv. 1 (1998). In a study of 26 women of color who were at different stages in graduate school for sociology, Margolis and Romero conducted 45- to 90-minute telephone interviews. The interview protocol was open-ended and allowed the participants to comment broadly 
Drawing on the work of Jack Haas and William Shaffir, ${ }^{139}$ the study defined professionalization as a

[P]rocess [that] includes several dimensions: developing and identifying with and committing oneself to the profession and a professional career; developing greater loyalty to colleagues than to clients; acquiring a certain detachment and routinization toward one's work; gaining formal knowledge and skills in order to make competent judgments; and developing a pretense of competence even though one may be privately uncertain. ${ }^{140}$

Based on interviews with women of color in a graduate sociology program, Margolis and Romero discovered that models of professionalism were imposed through a hidden curriculum comprised of implicit demands associated with graduate study. Among these demands were: (1) "show[ing] a business-like and detached attitude with respect to the subject of study" so that "feelings, intuition and interest" were not "allowed to play a role"; (2) working with "professional jargon and abstract concepts"; (3) "hold[ing] their own, by showing a confident attitude and giving little or no evidence of anxiety, nervousness or feelings of uncertainty in exams or interviews"; and (4) "learn[ing] to value "the satisfaction gained from achieving more and getting better results than others, which gives people also a sense of self esteem." "141 In addition to these universal forms of professional socialization, Margolis and Romero examined the unique burdens that racism and sexism imposed on women of color in graduate programs. The students interviewed considered these burdens an inherent but often hidden feature of departments that had historically excluded women and minorities when the normative vision of the ideal professional was developed. ${ }^{142}$

The women of color in the study found themselves stigmatized as "affirmative action" cases, with their qualifications regularly called into question by both faculty and fellow students regardless of their individual interests and abilities. ${ }^{143}$ Students who wanted to study issues or pursue work in their communities of origin frequently were discouraged on the ground that they could not address these issues with the necessary

on their graduate school experience. Of the 26 respondents, 11 were Black, 8 were Latina, 2 were Native American, and 5 were Asian American. Three also identified themselves as international students. The students ranged in age from 25 to 65 , with half between the ages of 25 and 35 . See id. at 4-5.

139. See Jack Haas \& William Shaffir, Ritual Evaluation of Competence: The Hidden Curriculum of Professionalization in an Innovative Medical School Program, 9 WORK AND OccuPATIONS 131 (1982).

140. Margolis \& Romero, supra note 138, at 6 (quoting Haas \& Shaffir, supra note 139, at 132).

141. Id. at 6-7 (quoting G. Bergenhenegouwen, Hidden Curriculum in the University, $16 \mathrm{~J}$. HIGHER EDUC. 535, 537 (1987) (citation omitted)).

142. See Margolis \& Romero, supra note 138, at 11-12.

143. See id. at 12-13. 
detachment and would be ghettoized within the profession. Students who persisted in these efforts were sometimes excluded from the program, and ultimately labeled as activists rather than intellectuals or professionals. ${ }^{144}$ Policy-relevant research was consistently dismissed as inferior to theoretical work. ${ }^{145}$

Students recalled how they encountered negative stereotypes of their groups in their courses; for example, one class attributed the problems of Puerto Ricans to a "culture of poverty," rather than to social, historical, and political factors. ${ }^{146}$ The absence of women of color in the student body and on the faculty created conditions of isolation and marginalization with no sense that the department was committed to changing this situation. ${ }^{147}$ The curriculum largely ignored issues of race and gender, and when women of color attempted to engage their classmates or teachers in discussions about race, their efforts were regularly met with "deafening silence." 148

Women of color seldom gained access to the best research opportunities, postdoctoral fellowships, publishing venues, or prestigious jobs. ${ }^{149}$ In response to these slights, the students maintained ties to their commumities, struggled to stay focused on social action, applied the tools of the discipline to dissect the contradictions surrounding race and gender in the department, and sought opportunities to fulfill their interests outside the department. ${ }^{150}$

A study by Anne J. MacLachlan on women and minority graduate students at the University of California at Berkeley replicated many of these findings. ${ }^{151}$ MacLachlan found that social distance between faculty and students is sometimes mcreased by differences in race, ethnicity, gender, and class background. Misunderstandings may be hard to correct, given a graduate student's dependence on an individual faculty advisor who is not held systematically accountable for his or her performance in offering support and guidance. ${ }^{152}$

Students on the whole expressed satisfaction with their advisors. However, they often made comments that turned the advisor's inattention into a virtue or that placed the blame for it on themselves. For example,

144. See id. at 21-24.

145. See id. at 13-15.

146. Id. at 15 .

147. See id. at 17-19.

148. Id. at 19.

149. See id. at 24 .

150. See id. at 24-28.

151. See Anne J. MacLachlan, Graduate Education: The Experience of Women and Minority Ph.D.s at U.C. Berkeley 1980-1989 (n.d.) (unpublished manuscript, on file with author). The author conducted interviews with 338 graduate students who received Ph.D.s from Berkeley between 1980 and 1989. The author oversampled both women and minorities. Of those interviewed, $41 \%$ were women, while $28.1 \%$ were Black, $15.7 \%$ were Asian American, $10.9 \%$ were Chieano, $1.5 \%$ were Latino, $13.3 \%$ were Native American, and $26.9 \%$ were White. See id. at 12.

152. See id. at 1-5. 
students said that Berkeley's "hands off approach" was a strong point because it enabled them to become self-reliant and self-motivating. ${ }^{153}$ Yet some students did acknowledge that racism, sexism, and classism harmed their educational experience, with one woman of color noting her advisor's "continual[ly] racist/sexist comments." the damaging effects of a "star system" that "marked [students] in their first year, or before they enter."155

Students sometimes reported that professors preferred graduate students who reminded them of themselves, and women and minorities often did not fit into that category. ${ }^{156}$ About one-fifth of the minority respondents brought up issues of race and ethnicity. They most often depicted Berkeley's climate as racially insensitive or hostile. ${ }^{157}$ Many felt "isolated and alienated" and often reported that they were "left to find their own way by themselves." 158 Dissertation topics on minority issues were discouraged or given little support. Some minority students felt that they were tracked into low-status occupations. ${ }^{159}$ According to MacLachlan, in the wake of the ban on affirmative action, "the issues raised by the students in this study seem more germane than ever."160

In addition to this study of graduate student life, the Institute for the Study of Social Change conducted a Diversity Project at Berkeley that used interviews and focus groups to explore the impact of diversity on undergraduate student life. ${ }^{161}$ The study found that at a relatively large and impersonal campus, all students were likely to report feeling isolated to some degree. ${ }^{162}$ Although stereotyping and balkanization did accompany high levels of diversity, most students valued the opportunity to have interracial contacts and were sometimes frustrated by their inability to reach out across racial and ethnic boundaries. In some instances, race correlated with different conceptions of diversity. White students, for instance, wanted to have informal friendships with Blacks, while Blacks preferred same-race friendships and wanted to interact with Whites in the context of structured programs and activities. ${ }^{163}$ Students' race or ethnicity also influenced their

\footnotetext{
153. See id. at 24-25.

154. Id. at 26.

155. Id. at 34 .

156. See id. One student noted that "[s]tars were upper middle class white males." $1 d$. at 26.

157. Of 47 minority respondents who addressed racial and ethnic concerns, 39 reported facing a hostile racial climate. See id. at 32 .

158. Id. at 33 .

159. See id. at $33,35-36$.

160. Id. at 40 .

161. See Institute for the Study of Social Change, University of California, Berkeley, The Diversity Project: FINAI RePORT (1991). Project researchers interviewed nearly 300 students in more than 60 group sessions held between 1989 and 1991, and over 150 hours of taped sessions were transcribed and analyzed thematically. See id. at 11,63-66.

162. See id. at 16.

163. See id. at $13-15,16-17$.
} 
views about affirmative action, though strong differences of opinion existed within each racial and ethnic group. Blacks, Latinos, and Native Americans expressed the strongest support for the programs, Whites were most dissatisfied, and Asian Americans were most ambivalent. ${ }^{164}$

Based on their findings, the Project researchers recommended that the University take systematic steps to promote small-group settings of ten to fifteen students in which problems of orientation, adjustment, and integration into campus life could be addressed. In addition, the report urged that the University encourage both racial and ethnic "support groups" and groups that would enable students to bridge racial and ethnic divides. The researchers also called on the University to take steps to clear up misconceptions about affirmative action and to involve faculty in facilitating more interaction among students around the curriculum. ${ }^{165}$ However, only a few years after the report's publication, its reform proposals seem almost archaic, as the elimmation of affirmative action has greatly reduced the racial and ethnic diversity of Berkeley's undergraduate population. ${ }^{166}$

\section{E. Summary}

The research on diversity in higher education reflects some of the normative anbiguity underlying race-conscious admissions progranis. Much of the quantitative research rests on an assimilative vision in which affirmative action eventually results in comparable achievement for Whites and non-Whites, counters harmful stereotypes and biases, and promotes tolerance and understanding through interracial contact. Assimilation is the end result of corrective justice: affirmative action will undo the harms of past discrimination by overcoming performance deficits and improving racial attitudes.

By contrast, a small body of qualitative work adopts a pluralistic perspective in assessing the educational climate in diverse institutions. These studies explore whether colleges and universities have capitalized on newly transformed student bodies by restructuring their classroom offerings, informal faculty-student contacts, and extracurricular activities. This research generally finds that Powell's vision has been imperfectly realized because nontraditional perspectives remain marginalized and because perceived balkamization has a chilling effect on student interaction. Faculty have not altered the formal or hidden curriculun1, and administrators have

164. See id. at 15.

165. See id. at 59-61.

166. The proportion of Berkeley's freshman class that self-identified as Black dropped from 7.3\% in Fall 1997 to 3.4\% in Fall 1998, while the proportion of Chicano students dropped from $11.1 \%$ to $5.7 \%$. The proportion of Latino students stayed about the same, that is, $2.3 \%$ in 1997 and $2.2 \%$ in 1998 . See Office of Student Research, Undergraduate Admissions Statistics, Fall 1997 at 1 (Jan. 21, 1998) (on file with author); Office of Student Research, Undergraduate Admissions Statistics, Fall 1998 at 1 tbl.1 (Dec. 14, 1998) (on file with author). 
not done enough to create opportunities for interracial contact. This work concludes that the benefits of diversity can be achieved only when institutions, and not just students, are expected to change.

III.

\section{The Boalt Hall Interview Project}

When Boalt Hall ended its affirmative action policies, the change afforded a unique opportunity to supplement existing research and explore different perspectives on the composition of the student population and its relationship to legal education. The interviews were designed to elicit views about the first-year classroom experience, study groups, extracurricular activities, social life, and admissions policies at Boalt. The study included first-year students admitted under a policy without affirmative action and second- and third-year students admitted under a policy that included affirmative action. Given the unprecedented transformation of the student body, in-depth interviews provided a means to explore the complex dynamics of this sudden shift without straightjacketing students by confining them to a strict protocol or forcing them to reduce their answers to numbers on a scale.

\section{A. Methodology}

The interviews were conducted in the spring semester of 1998, which gave first-year students the opportunity to develop some clear impressions of legal education. In addition, some of the intense controversy and media scrutiny about the change in admissions policy had dissipated, so that all students could reflect on the events with somewhat greater distance. To minimize the danger that the questioner's identity would influence responses, seven students conducted the interviews. ${ }^{167}$ These were first-, second-, and third-year law students from a range of racial and ethnic backgrounds. Five of the interviewers were women, and two were men. Two interviewers were White, two were Asian American, one was Latino, one was Black, and one was mixed-race. Before conducting the interviews, the seven students attended two general training sessions and participated in two mock interviewing exercises.

Participants were selected at random from the enrollment lists of the law school with the aim of generating approximately equal numbers of first-year students selected under the new admissions policy and secondand third-year students selected under the prior policy. At the outset, it was clear that the small number of Blacks and Latinos in the first-year class

167. Originally, there were to be eight interviewers. However, one interviewer, a White male, had to be dropped from the study because of difficulties in scheduling his appointments. The one interview he conducted was comparable in quality and content to those done by other interviewers, so quotations from that interview are included along with the rest of the material gathered. 
would require oversampling to obtain adequate representation. Later, the low numbers of Black and Latino participants from the second- and thirdyear classes required oversampling of this group as well. The reasons for the low participation are not entirely clear, although at least a few subjects reportedly refused on the ground that they had been studied enough. Perhaps this reluctance related to the faculty's reassessment of its admissions policy during the 1997-1998 academic year. Throughout these deliberations, faculty regularly noted the gap in the grade point averages and LSAT scores of White students and Black and Latino students admitted under affirmative action. This gap was used to demonstrate why a colorblind policy inevitably would lead to depressed numbers of Blacks and Latinos in the entering class. ${ }^{168}$ Undoubtedly, second- and third-year minority students found this form of scrutiny uncomfortable and demeaning.

Participants were sent a letter explaining the purpose of the interview, the ways in which their remarks would be kept confidential and reported without mention of their identity, and their right to terminate the interview at any time.$^{169}$ Participants then received a follow-up telephone call asking them to participate and offering to schedule an appointment for an interview. Participants were told that the interviews would take place at Boalt and would take about an hour. No remuneration was offered. A total of 185 letters were sent, but follow-up was unsuccessful in seventeen cases because students had moved or had their numbers disconnected without updating their records at Boalt. Of those successfully contacted, fifty-nine agreed to and did participate. Of these, thirty were women and twenty-nine were men. Thirty-six subjects self-identified as White, 11 as Asian American, 5 as Latino, 4 as Black, and 3 as mixed-race. Twenty-seven of the students were in the first-year class, while the remaining 32 students were evenly divided between the second- and third-year classes. Two of the students had transferred to Boalt from other law schools after their first year.

For the original sample, the overall response rate was thirty-two percent, while for the sample successfully contacted through follow-up calls the rate was thirty-five percent. Because only about one out of three students participated, there is sone possibility that self-selection bias affected the results. In particular, some might speculate that only the most intensely committed students agreed to participate. The interview results

168. These observations were based on simulations done the previous year, which showcd that a colorblind admissions policy based solely on grades and LSAT scores would reduce the number of underrepresented minorities at the law school to twelve or fewer. Pamela Burdman, Minority Enrollment at Boalt May Fall; Diversity to Suffer at UC Law School, According to Study, S.F. CHRON., Jan. 22, 1997, at A15.

169. These materials, the protocol for follow-up contacts, and the informed consent form were approved by the Human Subjects Committee on the Berkeley campus as satisfactorily protecting the participants' rights. 
themselves seem to belie this easy conclusion, however. A number of students who participated expressed appreciation for the opportunity to address a polarizing and volatile issue in a safe and comfortable environment. ${ }^{170}$ While some students had been actively involved in the controversy, others had become disillusioned by the debate or had kept their distance all along. Thus, it does not appear that the sample included only students who strongly favored or opposed affirmative action. Still, the dangers of self-selection bias cannot be wholly discounted.

The interviews were conducted using a semistructured protocol designed to ensure that all areas of interest were covered, but that interviewers could follow up on interesting responses when appropriate. ${ }^{171}$ The interview began by reiterating the student's rights and protections. Students were then asked to sign an informed consent form to indicate that they had been told about these protections and rights and understood them. Once the form was signed, the interviewers "broke the ice" with questions about what students did before law school, why they came to law school, and whether law school had met their expectations. The interview then moved on to explore the student's classroom experience during the first year of law school. In addition to asking about classroom discussions and patterns of participation based on race, ethnicity, and gender in large and small sections, the interviewers asked students to describe comments made about particular cases typically covered in the first-year curriculum. ${ }^{172}$ Three of the cases were designed to see how often race figured in the discussion, ${ }^{173}$ and three were designed to see how often gender figured in the discussion. ${ }^{174}$ One vignette on race was administered to a few students but

170. Anecdotal accounts of Boalt students' experiences during the 1997-98 academic year suggest that at least some students felt silenced by the intense debate over affirmative action. See THE Diversity HOAX: LAW STUDENTS REPORT FROM BERKELEY, supra note 19, at 6-8.

171. A copy of the protocol is attached as Appendix A.

172. The case vignettes are included as Appendix $B$.

173. The three cases were Katzenbach v. McClung, 379 U.S. 294 (1964), People v. Goetz, 497 N.E.2d 41 (N.Y. 1986), and United States v. Starrett City Assocs., 840 F.2d 1096 (2d Cir. 1988). Katzenbach dealt with whether Congress could insist that restaurants offer service to Blacks based on the power to regulate interstate commerce. See 379 U.S. at 296-97. Goetz examined whether a White man's fear for his safety was reasonable and therefore justified shooting several Black youths on a subway. See 497 N.E.2d at 43-46. Starrett addressed whether a housing agency could cap the number of non-Whites in a government-subsidized project to prevent White flight. See 840 F.2d at 1098-2000.

174. The three cases were State v. Kelly, 478 A.2d 364 (N.J. 1984), In re Baby M., 537 A.2d 1227 (N.J. 1988), and Korman v. Mallin, 858 P.2d 1145 (Alaska 1993). Kelly dealt with battered women's defense and when a woman can justifiably kill an abusive husband or boyfriend, even if her own life is not immediately threatened when she acts. See 478 A.2d at 368-69. Baby $M$. analyzed whether a woman can be bound by a contract that requires her to relinquish an infant whom she conceived as a surrogate mother. See 537 A.2d at 1234-35. Korman involved a woman who had breast reduction surgery and subsequently sued her physieian for failure to obtain an informed consent. See 858 P.2d at $1146-48$. 
eventually dropped because it seriously conflated race and class issues. ${ }^{175}$ The six cases were drawn from a range of first-year courses, including two from Criminal Law, one from Property, one from Contracts, one from Torts, and one from Constitutional Law. Students were presented with a vignette of one case. If they failed to recognize it, they were shown another. If they failed to recognize that one as well, they were shown the third. If a student did not recognize any of the vignettes, he or she was asked to recall a case in which race or gender figured in the discussion. Although vignettes on race always preceded those on gender, the order im which each set of vignettes was presented varied. ${ }^{176}$

After dealing with classroom experience, students were asked about their contact with faculty outside of class and whether they studied alone or in groups. If they studied in a group, they were asked about the racial, ethnic, and gender make-up of the group and the content of group discussions. The interviewer next inquired about students' extracurricular activities. In particular, students were asked what activities they participated in, their reasons for joiming, and the racial, ethnic, and gender make-up of the organizations' leadership and general membership. The interviewers then turned to social life, asking people to describe their close friends at Boalt. Interviewers asked how students met their friends, what they shared in common, and how they would describe their friends in terms of race, ethnicity, and gender.

The final part of the interview focused on Boalt Hall's admissions policy. Students were first asked to explain what the admissions policy had been before affirmative action was eliminated, what the policy currently was, and whether the faculty and administration were considering any changes to the present policy. These questions were designed to reveal how familiar the participants were with the specific issues surrounding Boalt's system of admissions. Students were then asked to describe their ideal admissions policy and any advice they would offer prospective students. In this way, participants were free to offer normative judgments as well as descriptive accounts and to frame their answers in the abstract or in the concrete. At the conclusion of the interview, each participant was asked whether he or she had anything else to add. The interviewer then requested some basic demographic information about age, race, and ethnicity and thanked the person for participating. Those who were interviewed subsequently received a written note of appreciation.

175. The case was Williams v. Walker-Thomas Furniture Co., 350 F.2d 445 (D.C. Cir. 1965), which dealt with whether installment contracts were unconscionable because they exacted extremely high fees from poor Black consumers in Washington, D.C., who could not pay for goods in full and lacked access to other sources of credit.

176. Ideally, the order of vignettes on race and gender would have varied. It is not clear whether there were any ordering effects because race vignettes always preceded those on gender. 


\section{B. Results}

This section is divided into the key areas covered during the interviews. These include; (1) reasons for attending law school; (2) classroom experience; (3) contact with faculty; (4) study groups; (5) extracurricular activities; (6) social life; and (7) admissions policy.

\section{Reasons for Attending Law School}

When John F. Kennedy was awarded an honorary degree from Yale, he quipped that he had the best of both worlds: a Harvard education and a Yale degree. ${ }^{177}$ His humor played on the distinction between getting a credential and gettimg an education. This distinction is one that resonates with responses to inquiries about why students choose to come to law school. Students tended to fall into two groups: (1) those who had come to law school mainly by default or because it seemed like a good way to make money, and (2) those who had come primarily because they wanted to build a professional identity or promote a personal vision of service to society. For the first group, the decision was in many ways divorced from their personal identities. Law would just be a job, not a critical form of self-actualization. For the second group, law school was the first step in developing a sense of self that turned heavily on professional commitments.

\section{a. Detached Reasons for Coming to Law School}

Some students made it clear that financial security was a principal reason for pursuing law study. As a forty-six-year-old White male student in the first-year class put it: 'I've always had an interest in the law, and 1 got in the latter half of my life, and I thought, 'Oh, I guess I better figure out some way to make money." 178 A twenty-four-year-old Latina in the first-year class explained that "I come from a lower middle-class family, and I wanted to make more money and be more comfortable with my life instead of always worrying about it." 179

These students sometimes cane with few expectations about law school. A twenty-five-year-old White male in the first-year class had concluded that a career in publishing would not be satisfying and came to law school "to have some more options as to what I wanted to do" despite having no particular interest in the law. As a result, when asked whether law school inet his expectations, this student replied: "I didn't really have

177. See President John F. Kennedy, Sr., Commencement Address at Yale University (June 11, 1962), in Public Papers of the PResidents I962, at 470 (1963).

178. Interview by Interviewer G with Student No. 33 in Berkeley, Cal. (Apr. 23, 1998) (White male) (transcript on file with author).

179. Interview by Interviewer $G$ with Student No. 51 in Berkeley, Cal. (Apr. 23, 1998) (Latina female) (transcript on file with author). 
that many expectations. I didn't really know too much about law school at all. In a sense, yes." ${ }^{180}$ A forty-year-old White woman who was an upperdivision student explicitly rejected the idea that a law degree was anything more than a credential: "It's an entree to get certain jobs. . . . I think other people expect it will help them find whoever they are . . but I didn't expect that."181

This sense of drifting into law school is echoed by students who made clear that their decision was by default, or a way to delay getting a job. A twenty-four-year-old Korean male in his third year came to law school because "I always kind of had it in my head that I would be a lawyer, and I couldn't think of anything I could do after I graduated."182 As a twentyfour-year-old Latino male in the first-year class remarked, a big part of his decision was "that I didn't feel like I was ready to start my career, so it gave me a chance to live the life of a student for another three years. That was as least as much of a factor as my interest in law." 183 A twenty-sixyear-old White male in the third-year class concurred, saying he attended law school despite the fact that he "wasn't definitely sure I wanted to be a lawyer. It was sort of a good way to put off life for three years." 184

Some students recognized that their reasons for becoming a lawyer were not socially valued. One upper-division, twenty-five-year-old Korean male put it most succinctly, calling it "a default sort of thing. I took the LSAT on a lark, and I got a good score and got imto a top ten school, and here I am. That's not what I wrote on my personal statement [to be admitted]."185 Another student, seemingly aware that her reasons could seem insubstantial, tacked on a desire to do good at the end of her answer. When asked why she came to law school, this twenty-three-year-old White

180. Interview by Interviewer G with Student No. 114 in Berkeley, Cal. (Mar. 30, 1998) (White male) (transcript on file with author). Other students who came to law sehool because of limited opportunities in other fields often perceived law as the most promising alternative to the career they had previously chosen. See, e.g., Interview by Interviewer G with Student No. 47 in Berkeley, Cal. (Apr. 16, 1998) (transeript on file with author) (thirty-year-old White male in second-year class); Interview by Interviewer F with Student No. 71 in Berkeley, Cal. (Apr. 27, 1998) (transcript on file with author) (twenty-five-year-old White female in joint degree program); Interview by Interviewer $D$ with Student No. 115 in Berkeley, Cal. (Mar. 30, 1998) (transcript on file with author) (twenty-sixyear-old White female in first-year class).

181. Interview by Interviewer C with Student No. 66 in Berkeley, Cal. (Mar. 11, 1998) (White female) (transcript on file with author).

182. Interview by Interviewer B with Student No. 133 in Berkeley, Cal. (Mar. 18, 1998) (Asian-Aneriean male) (transcript on file with author). See also Interview by Interviewer $\mathrm{E}$ with Student No. 120 in Berkeley, Cal. (Mar. 18, 1998) (White male) (transcript on file with author) ("I really didn't have anything else to do.").

183. Interview by Interviewer H with Student No. 30 in Berkeley, Cal. (Apr. 3, 1998) (Latino male) (transcript on file with author).

184. Interview by Interviewer E with Student No. 56 in Berkeley, Cal. (Apr. 2, 1998) (White male) (transcript on file with author).

185. Interview by Interviewer $G$ with Student No. 43 in Berkeley, Cal. (Mar. 9, 1998) (Asian-American male) (transcript on file with author). 
female in the second-year class replied: "I've been asking myself that question many times recently. I wanted to be a professional. I loved watching L.A. Law as a kid and nothing else kind of came to me. I guess I wanted to do some good for society, too."186

\section{b. Engaged Reasons for Coming to Law School}

In contrast to students who saw law school as a way to earn a credential or to mark time, some participants saw law as a way to build an identity or to effect social change. A twenty-seven-year-old Black male in his third year expressIy rejected credentialing as his reason for coming to law school:

I came to law school largely because I wanted the tools law provides. Namely that when you're dealing with the law, you're dealing with how people allocate resources amongst each other, and I was very much interested in knowing about those rules and being a part of the people that are knowledgeable about those rules.... I never saw it ... in terms of being a lawyer for a lawyer's sake. ${ }^{187}$

A twenty-two-year-old White female in the first-year class linked identity, personal fulfillment, and public service in describing her reasons for coming to law school:

I was one of those kids who wanted to be a lawyer when I was four years old.... I interned at a community outreach law program that the New York City Bar Association was associated with. I served as a translator at legal clinics around Manhattan basically doing elder law and immigration in Spanish-English. I just did a lot of work and saw how there was this huge need that wasn't being filled in and giving legal services to Spanish speakers, and so that's why I initially came here. ${ }^{188}$

A thirty-year-old White woman in her first year of law school explained that having done political organizing for large groups, she preferred "advocating for individual people and their individual problems so I thought that I would be able to do that more if I was a lawyer." 189 Another

186. Interview by Interviewer B with Student No. 69 in Berkeley, Cal. (Apr. 7, 1998) (White female) (transcript on file with author).

187. Interview by Interviewer F with Student No. 23 in Berkeley, Cal. (Apr. 28, 1998) (Black male) (transcript on file with author).

188. Interview by Interviewer A with Student No. 90 in Berkeley, Cal. (Mar. 17, 1998) (White female) (transcript on file with author).

I89. Interview by Interviewer F with Student No. 42 in Berkeley, Cal. (Apr. 20, 1998) (White female) (transcript on file with author). See also Interview by Interviewer B with Student No. 59 in Berkeley, Cal. (Apr. 14, 1998) (transeript on file with author) (twenty-nine-year-old White male in the second-year class who "came in as sort of an idealist" who "wanted to fix the world, right some wrongs"); Interview by Interviewer F with Student No. 60 in Berkeley, Cal. (Mar. 12, 1998) (transcript on file with author) (twenty-seven-year-old White female in joint degree program who wanted to do 
twenty-seven-year-old White female in the third-year class called her commitment to law "a public service. I also wanted something that is highly intellectual and rigorous. I thought that law could be a better thing for me. I like to argue."190

\section{c. Powell's Vision and Reasons for Coming to Law School}

Students arrive with distinct notions about their relationship to the educational experience. Some treat their education as a commodity, "an entree to . . . certain jobs." Although the issue deserves further study, these students seem unlikely to participate in the robust exchange of ideas that Powell envisioned unless they receive some direct reward for their efforts, nor do they seem apt to share personal experiences and perspectives that challenge the status quo if doing so would diminish the value of their credential. In short, these students are likely to be instrumental in mastering technical skills while preserving some emotional and social distance from the educational process.

By contrast, students who see law as a calling are likely to want to integrate their educational and professional experiences with a sense of personal identity. They may be willing to share individual stories and viewpoints in an effort to meld their personal values and legal training. For these students, detachment is not a coping strategy but a destructive form of alienation. They want more than a good job that brings high pay and prestige; they want a career that leaves them feeling fulfilled and committed.

\section{Classroom Experience}

Just as students arrived with very different reasons for pursuing legal study, they also expressed disparate views about the nature of the learning process. Soine thought of the law as a set of abstract principles and methods of reasoning that they had to master to succeed in school. These students generally thought of the educational experience as hierarchical: the professor was an authority on the rule of law, and it was the student's job to ferret out the doctrinal principles and on occasion the policy and theory that the professor had in mind. Another group of students understood the law in more political terms: it should reflect the values of the communities it served. Far from being an abstraction, the law was a concrete set of judgments that needed to be regularly revisited on the basis of collective experience. These students were generally receptive to broad-ranging class

\footnotetext{
"advocacy for women and children and social services"); Interview by Interviewer F with Student No. 80 in Berkeley, Cal. (Mar. 18, 1998) (transcript on file with author) (twenty-six-year-old Latino male in first-year class who came to law school "to effect social change in the United States").

190. Interview by Interviewer E with Student No. 8 in Berkeley, Cal. (Mar. 18, 1998) (White female) (transcript on file with author).
} 
discussions in which they argued with their peers about norms and shared personal experiences.

\section{a. Student Reactions to the First-Year Instructional Process}

Most students reported that their classroom experience was hierarchical with the professor exercising considerable power over which issues could be raised. As one student explained, "There's nothing much that 1 can say except that the professors run the class; they run the show; they are perfectly free to structure the lecture however they want. They cannot call on certain people, they can request that people ask a question outside of class in office hours." 191

While some students were comfortable with the professors' exercise of authority, one transfer student stood out because he so highly prized the Socratic method, particularly as it had been employed at the school he attended his first year. He believed that professors should use their power in the classroom to set high standards, and he described himself as "appalled" at the way Boalt students were coddled by receiving advance warning that they would be called on and by being allowed to pass when not prepared. ${ }^{192}$ This student believed that the Socratic method was not properly utilized at Boalt because the faculty had chosen the pedagogical path of least resistance. In his view, faculty were lenient not because they cared about students but because research and writing were more emphasized in tenure decisions than teaching:

[I] takes a lot of work for the professor ... to ask the engaging Socratic questions and do all of that. That takes a lot of work and effort, a lot of work and effort that I think Berkeley professors spend their time writing papers like this [the present Article based on the interviewing project]. It's a different philosophy of education. I think the professor has a lot to do with it. ${ }^{193}$

Although this student held hierarchical methods of teaching in high regard, other students resented the power that the faculty exercised over the curriculum:

[T] he pedagogical model doesn't seem to be one where you can get away with disagreeing with your professor. I think that as our campus becomes more and more standardized, I think things are pretty conservative here ... and we're pretty much a clearinghouse for corporate law firms. I think that's a dangerous recipe in a public institution. The professor really needs to encourage people to be thinking critically, not just thinking in line, toeing the party line, toeing the easy thing that the professor is putting out there as the

191. Interview with Student No. 56, supra note 184.

192. Interview by Interviewer D with Student No. 37 in Berkeley, Cal. (Mar. 11, 1998) (White male) (transcript on file with author).

193. Id. 
answer. Making critical inquiries into the questions that are being asked and the issues that are being presented and offering divergent points of view that don't necessarily line up with what the professor is saying. I think that is a challenge to any good teacher to let somebody offer a point of view which he or she does not agree [with] personally and help the student to frame that well and formulate that well and offer good support for those points of view. ${ }^{194}$

Such lack of critical inquiry led one student to call law school "intellectually stunting":

I feel like law school has engaged me to learn a certain set of tools in a base sort of way. I think I can use those tools and make those discussions with people I select, but I don't think that necessarily happens, at least in the majority of my classes. . . Most of them have been trying to give me rules and think like a lawyer, which is fine, but I think you need to think in a larger realm . . . . To think like a lawyer and what is a lawyer's role in larger society, I don't think I've gotten that at this school, except in a few classes. . . . [I]t has been disappointing in some ways. ${ }^{195}$

On the other hand, some students also thought that their peers bore some responsibility for the intimidating nature of the classroom experience. A White male in the upper division characterized large lecture classes as "Ionely and scary" saying, "[The classroom experience] really sucks because I know my classmates are professionals, and . . . I know that it is a judgmental atmosphere in the first place, and then you never get feedback. . . . So, it seems bizarre and crazy." ${ }^{196}$ Another White male in the upper division described how some vocal classmates censored broader participation:

They're all very self-righteous. I would characterize them as very self-righteous. My first year, they were the type of people I would try very hard not to be with im every sense of law school life. They

194. Interview with Student No. 59, supra note 189.

195. Interview with Student No. 8, supra note 190. Several students expressed the view that their commitment to social change was sorely tested during the first year when the curriculum did not speak to their interests. See, e.g., Interview by Interviewer F with Student No. 45 in Berkeley, Cal. (Apr. 24, 1998) (transcript on file with author) (twenty-eight-year-old White female in upper division); Interview hy Interviewer G with Student No. 53 in Berkeley, Cal. (Mar. 19, 1998) (transcript on file with author) (twenty-seven-year-old White male in upper division); Interview with Student No. 60, supra note 189 (twenty-seven-year-old White female in joint degree program) ("I really craved ... more practical applications .... At least to this point, I'm now midway through my second year of law school, and it feels like I've gotten nothing.").

196. Interview by Interviewer A with Student No. 52 (Apr. 21, 1998) in Berkeley, Cal. (White male) (transcript on file with author). This student disliked the lack of feedback offered by professors during the semester, equating it to learning mathematics without actually doing the problems. See id. 
were boisterous, condescending, and I never really thought they ... were adding the most insightful points. ${ }^{197}$

Although other White males concurred in depicting the classroom atmosphere as oppressive, many students thought the burden fell most heavily on women and people of color. According to a Black male in the second-year class:

I think women and minorities can feel silenced. I think most professors are White males, so White males feel more comfortable participating. But ... I've actually felt a little bit more emboldened to participate because I feel like if I don't, then people are going to say, "That person doesn't really know anything about the law. They don't really know what they're talking about." So I feel like it's more of a duty for women and people of color to participate and kind of add to the discussion. ${ }^{198}$

Similarly, a Korean male noted that while some men were intimidated, the women bore the brunt of the competitive classroom atmosphere:

My experience definitely is that my women friends are far more unhappy with large classes and feel like it's a huge effort for them to speak up in those classes. I've actually had discussions with friends who... made a pact with each other that they would ... basically [try] to force each other to talk in class, and they would make an effort to be a presence and be heard in these classes. Certainly, there are men who have the same or similar feelings. I didn't hear any men coming up with these plans of how to have the courage to speak up in these large groups and not feel flattened by the professor. ${ }^{199}$

Some students believed that the teaching of law was hierarchical but that students could challenge the prevailing wisdom in important ways. As a Latino student explained:

Whenever you have those discussions [of race], it challenges the White students to think about the way they're being taught or what they're learning in a different way. In my opinion, that's a good challenge because in this context of the law school, if there's going to be anything done ... in terms of race relations, the first thing that has to happen is a dialogue or discussion or recognition of racism.... Without students of color bringing it up, the chances of that are very, very slim. ${ }^{200}$

197. Interview with Student No. 53, supra note 195 .

198. Interview by Interviewer E with Student No. 62 (Apr. 14, 1998) in Berkeley, Cal. (Black male) (transcript on file with author).

199. Interview by Interviewer B with Student No. 65 (Apr. 20, 1998) in Berkeley, Cal. (Asian-American male) (transcript on file with author).

200. Interview with Student No. 80, supra note 189. 
A Latina in the first-year class also expressed her concern that she might be missing something because of the lack of diversity in her class:

[E]xperiencing discrimination for yourself is an incredibly different viewpoint than ... never having actually experienced it yourself. I think that's a subtle thing. ... A lot of good points do come up, and I think that people are very sensitive to it, and I've appreciated that. But on the other hand it does bother me on a small level. I do feel that there may be some viewpoints that aren't coming out, and I do think about it when we discuss racial issues. There is no Black person in the entire class [that is, her large section]; there are three of us that are Spanish. ${ }^{201}$

On the other hand, one White woman resented that students of color assumed that only they could truly understand racial issues, calling the attitude "antagonistic toward White students. ${ }^{n 02}$ She described how minority students in the second- and third-year classes visited her first-year section of Criminal Law to make the point that minority perspectives were absent:

It sort of typifies how I feel that students address race issues here at Boalt. Up until that day, I belonged to CDF/SB [Coalition for a Diversified Faculty and Student Body], and I was really involved in the Boalt 2000 stuff [a student-generated initiative to overturn Proposition 209's ban on affirmative action], and I quit that day. I'm no longer part of any of those groups because I don't agree with third- and second-years in indoctrinating first-years and tryimg to tell them what they should be doing....I felt that it was offensive.... There are so many students here that have this idea that White students don't have any image of what it is to face prejudice or whatever. They have no idea what my background is or what kind of town I live in, where I went to school, who my friends were in school, and what my personal commitments are. ${ }^{203}$

In general, then, students perceive the first-year classroom as a hierarchical environment in which their contributions must fit within the professor's agenda. Although students may arrive with diverse experiences and viewpoints, they all must learn to "toe the party line," a process that some find "intellectually stunting." Those students of color who take seriously the notion that their perspectives should be included see themselves in an uphill fight to challenge the status quo. Some believe that they must struggle not only against the professor's unquestioned authority, but also against their classmates' discomfort and anxiety in addressing racial issues. Meanwhile, some White students resent non-White peers who appropriate race as their exclusive domain. Once again, diversity cannot automatically

201. Interview with Student No. 51, supra note 179.

202. Interview with Student No. 90, supra note 188.

203. Id. 
be equated with the robust exchange of ideas that Powell envisioned. This exchange depends just as importantly on the tolerance and receptivity of professors and classmates as on the presence of students of color.

\section{b. Recollections of Specific Cases Taught in the First-Year Curriculum}

The varied impact of diversity on first-year class discussion is confirmed by the students' recollection of the cases described in the vignettes presented to them. The vignettes were not pretested, but they were chosen with an expectation that the cases had elicited discussions of race and gender in class. In fact, the vignettes produced a range of responses about the extent to which these issues were addressed. Two cases yielded little or no recollection that these issues were discussed. Two others often, but not always, triggered memories of a meaningful treatment of race and gender. The two cases that consistently evoked vivid accounts of debates about these concerns both arose in Criminal Law.

\section{$i$. Cases that Evoked Little Discussion of Race or Gender.}

In general, students reported that there was no discussion of race in conjunction with Katzenbach v. McClung, ${ }^{204}$ a Supreme Court decision that addressed whether Congress could prohibit racial discrimination by privately owned restaurants or motels based on its ability to regulate interstate commerce. Students uniformly reported that the analysis in class focused on the permissible scope of congressional regulation under the Commerce Clause. ${ }^{205}$ Indeed, one student complained that the class was so narrowly focused that it should have been called "Commerce Clause Law" instead of "Con Law."206

204. 379 U.S. 802 (1964).

205. See, e.g., Interview by Interviewer F with Student No. 6 (Apr. 6, 1998) in Berkeley, Cal. (mixed-race male with Asian-American ancestry) (transcript on file with author); Interview with Student No. 8, supra note 190; Interview with Student No. 23, supra note 187; Interview by Interviewer B with Student No. 26 (Apr. 29, 1998) in Berkeley, Cal. (White female) (transcript on file with author); Interview with Student No. 30, supra note 183; Interview by Interviewer D with Student No. 39 (Apr. 7, 1998) in Berkeley, Cal. (White male) (transcript on file with author); Interview with Student No. 47, supra note 180; Interview by Interviewer F with Student No. 50 (Apr. 28, 1998) in Berkeley, Cal. (Black male) (transcript on file with author); Interview with Student No. 5I, supra note 179; Interview with Student No. 56, supra note 184; Interview by Interviewer D with Student No. 58 (Apr. 9, 1998) in Berkeley, Cal. (Asian-American female) (transcript on file with author); Interview by Interviewer D with Student No. 61 (Apr. 17. 1998) in Berkeley, Cal. (White male) (transcript on file with author); Interview with Student No. 65, supra note 199, Interview by Interviewer A with Student No. 68 (Apr. 24, 1998) in Berkeley, Cal. (White male) (transcript on file with author); Interview with Student No. 69, supra note 186; Interview by Interviewer F with Student No. 75 (Mar. 16, 1998) in Berkeley, Cal. (White female) (transcript on file with author); Interview by Interviewer F with Student No. 84 (Mar. 17, 1998) in Berkeley, Cal. (Asian-American female) (transcript on file with author); Interview with Student No. 115, supra note 180; Interview with Student No. 120, supra note 182.

206. Interview with Student No. 47, supra note 180 . The only time a student reported an attempt to discuss race in Constitutional Law was a class in which a Black student raised the question of whether Blacks were entitled to reparations for past discrimination, just as Japanese Americans had been compensated for internment during World War II. A White classmate found this student's 
Constitutional law professors generally did not attempt to describe the historical context in which Katzenbach arose, and everyone took for granted that racial discrimination was harmful. One student believed that this ahistorical approach silenced students of color by ignoring the racial discrimination leading to the decision. ${ }^{207}$ Other students indicated that the Commerce Clause so dominated the classroom discussion that they never understood why the decision was not predicated on the Fourteenth Amendment's guarantee of equal protection under the law: "I guess we really didn't discuss what precipitated this. Why was it there was even a reason to use the Commerce Clause? Why did the Commerce Clause have to come through the Civil Rights Act of 1964 ? Is it an equal protection issue? We didn't discuss any of that."208

Stripped of historical context and without any analysis of why Congress was forced to rely on the Commerce Clause to coinbat private discrimination, Katzenbach became an easy target for ridicule:

[The professor] was subtly making fun of this decision because I think he thinks that the Commerce Clause has too much power, and it's not that I think that he's in favor of discrimination, but more like he doesn't think that this decision was right under the Commerce Clause. I kind of remember him not taking seriously the idea that this restaurant, which is basically a local restaurant, that discrimination [there] would have any effect on interstate travel for Blacks .... .09

A Black student expressed his dismay with this approach to the case: "[W]e only talked about discrimination when [the professor] asked, 'Well, where in the Constitution does it say the private employer can't discriminate?' Maybe it's not written in the Constitution, but the heart of the Constitution says something like that."210

Similarly, in a first-year course in Torts, Korman v. Mallin ${ }^{211}$ did not evoke discussion of gender issues. Korman dealt with whether a woinan had given informed consent to breast reduction surgery. Professors apparently did not focus on the ways in which informed consent doctrine grew out of the women's movement and its emphasis on the right to control one's own body. Instead, faculty emphasized the doctrinal implications of

remarks "simplistic," and the professor and peers "shut [him] down in that." Interview with Student No. 52, supra note 196.

207. See Interview with Student No. 8, supra note 190.

208. Interview with Student No. 50, supra note 205. See also Interview with Student No. 47, supra note 180 (wondering why the case was not decided under the Fourteenth Amendment); Interview with Student No. 65, supra note 199 (expressing similar concerns about the relevance of the Fourteenth Amendment to the discussion).

209. Interview with Student No. 115, supra note 180.

210. Interview with Student No. 50, supra note 205.

211. 858 P.2d 1145 (Alaska 1993). 
the case. ${ }^{212}$ According to one student, the case did elicit "almost high-schoolish jokes about breast reduction surgery" 13 from his classmates, while another student reported that her professor "couldn't say the word 'breast' without getting a smirk on his face ...."214 Only one student out of seven who recalled the case reported a sigmificant discussion of gender-related issues in a class taught by a female faculty member. ${ }^{215}$

\section{ii. Cases that Evoked Some Discussion of Race and Gender}

The treatment of the Baby $M$. case, ${ }^{216}$ in which a woman agreed to serve as a surrogate mother and then refused to relinquish the child, varied from one Contracts class to another. Some professors chose to analyze the decision in terms of which kinds of goods should be commodifiable, that is, subject to being bought and sold. As a Latina in the first-year class explained, rather than emphasize gender-specific concerns, "the discussion here was based on whether or not there were some things you could or couldn't contract. You can't sell your eyes, you can't sell certain things, you shouldn't be able to sell a human child on that sort of level." ${ }^{217}$ Another student noted that the professor was "very much a contractarian. Everything can be contracted for." ${ }^{218}$ A White male, who identified himself as a Christian, found himself "horrified" by arguments "that we should let the free market regulate the purchasing and selling of children" because "the people in the classroom are going to be the people that set a lot of the policies in the nation in the future."219

However, in other classes, gender was a salient issue in the discussion. ${ }^{220}$ Gender concerns were especially likely to emerge in classes taught by a woman professor. Indeed, the emphasis in one female professor's class was sufficiently distinctive that some disgruntled students

212. See Interview with Student No. 6, supra note 205; Interview by Interviewer E with Student No. 46 (Mar. 12, 1998) in Berkeley, Cal. (White female) (transcript on file with author); Interview by Interviewer E with Student No. 49 (Apr. 15, 1998) in Berkeley, Cal. (White female) (transcript on file with author); Interview by Interviewer G with Student No. 79 (Apr. 13, 1998) in Berkeley, Cal. (Asian-American female) (transcript on file with author); Interview by Interviewer F with Student No. 131 (Mar. 30, 1998) in Berkeley, Cal. (Asian-American female) (transcript on file with author). The number of students who addressed this case was smaller than some of the other cases, either because students did not study the case or because they failed to remember it if they had.

213. Interview with Student No. 6, supra note 205.

214. Interview with Student No. 66, supra note 181.

215. See Interview by Interviewer F with Student No. 34 (Apr. 23, 1998) in Berkeley, Cal. (White female) (transcript on file with author).

216. In re Baby M., 537 A.2d 1227 (N.J. 1988).

217. Interview with Student No. 51, supra note 179.

218. Interview by Interviewer C with Student No. 77 (Apr. 9, 1998) in Berkeley, Cal. (White female) (transcript on file with author).

219. Interview with Student No. 52, supra note 196.

220. See, e.g., Interview with Student No. 33, supra note 178; Interview with Student No. 42, supra note 189; Interview with Student No. 50, supra note 205; Interview with Student No. 59, supra note 189; Interview with Student No. 61, supra note 205; Interview with Student No. 69, supra note 186; Interview with Student No. 115, supra note 180. 
complained that the course was about "Critical Women's Theories" instead of Contracts. ${ }^{221}$ When $B a b y M$. was treated as a case about gender, there was sometimes an impact on the relative participation by men and women. A Latino in his first year of law study noted:

[A] lot of females voiced their opinions in this case, but only because I don't think a lot of guys would know what it's like to experience that, having given birth to a baby.... Actually, I do remember having a discussion with the guy sitting right next to me who ... thought that law should just come down and say ... "For public policy, we're not going to allow you to make contracts of this type because you won't be emotionally stable whenever you have to give up the baby and everything, so we understand this, even if you may not, so we won't let you do it." ... [T] he reason that he didn't come through and say it was because it would have gotten a pretty big uproar from the women in the class. ${ }^{222}$

When asked about discussions of race in Property class, students once again indicated that the professor played a significant role in setting the tone for discussion. Just as a woman on the faculty was taken to task by some students for emphasizing gender in her Contracts course, a faculty member of color who developed racial issues throughout his Property class was criticized by some students as introducing mappropriate subject matter into the course. Because property doctrines would be on the bar exam, several felt that their education suffered as a result of the professor's unconventional approach. ${ }^{223}$

Regardless of the professor, the Starrett City $^{224}$ case on racial quotas in public housing produced discussions of the legitimacy of capping the proportion of non-White residents to preserve integration and prevent White flight. ${ }^{225}$ As with Katzenbach, students and faculty generally

221. Interview with Student No. 61, supra note 205.

222. Interview with Student No. 30, supra note 183. A White woman in the first-year class also expressed her dismay that her classmates treated Baby $M$. as a case about women's economic autonomy, rather than the best interest of the child. In her view, the key question was "Are they [women] really free acting agents if a woman needs twenty thousand or however much a woman can make for being a surrogate parent?" Interview by Interviewer B with Student No. 96 (Apr. 3, 1998) in Berkeley, Cal. (White female) (transcript on file with author).

223. See Interview with Student No. 43, supra note 185 (describing how "people... snicker" when told they learned something in Property). See also Interview by Interviewer D with Student No. 9 (Mar. 19, 1998) in Berkeley, Cal. (White male) (transcript on file with author) ("We didn't talk about cases in Property."); Interview with Student No. 77, supra note 218 ('You're reading a lot of cases that seem not to have really any connection to the black letter law. [The professor] could have done the class a lot better by connecting it to the black letter law."); Interview with Student No. 133, supra note 182 ("[The professor] taught the class with a liberal race theory in Property, and he was all the time talking about how people of color got oppressed by the old property laws. He encouraged sort of a liberal tip in everything in his class.").

224. United States v. Starrett City Associates, 840 F.2d 1096 (2d Cir. 1988).

225. See, e.g. , Interview with Student No. 34, supra note 215; Interview with Student No. 42 , supra note 189; Interview with Student No. 46, supra note 212; Interview with Student No. 96, supra 
assumed that the "tipping factor" that triggered an exodus of Whites was a product of racial prejudice, so the key question was whether the government could accommodate this prejudice in trying to eradicate it. In some instances, the emphasis on an easy moral consensus led to limited treatment of the issues: "When we discussed equal housing, I don't even remember if we did a case, or if [the professor] just brought it up. The sentiment I remember was, 'Obviously that's wrong and that there can be no excuse for it." ${ }^{226}$ By focusing on the reprehensible nature of racism, the professor and students could distance themselves from more taxing moral questions about the pervasiveness of White flight and the intractability of residential segregation.

A White woman reported that the insistence on the central role of racism stifled the discussion of Starrett City:

People would try to say things like "People could be moving in and out of a neighborhood for reasons that sort of do look like racism but actually could be explained by other things, like fear that housing property values could go down" or whatever and [a White male classmate] would just sort of jump all over them... The minute somebody tries to say there could be a reason for a White family moving out, he hears that and says, "That's racist."... If you tried to say anything at all than other than racism is what motivated the whole thing, you were, according to this guy, coming from the wrong perspective. ${ }^{227}$

While one White woman in the first-year class reported a lively but time-pressured debate over the relevance of race and class in Starrett City, ${ }^{228}$ others felt the lack of diversity in the first-year class hampered discussion of such cases. One White male commented on how the discussion was "[1]argely uninformed by real life experience of something like this" and took "for granted that it would be harmful to everybody ... if there was a White flight from the building." 229 A White woman remarked that "I thought it was really interesting that we were talking about White flight and what kind of happens when too many minorities live in the area,

note 222; Interview by Interviewer A with Student No. 103 (Mar. 13, 1998) in Berkeley, Cal. (White female) (transcript on file with author); Interview with Student No. 114, supra note 180. Two students, both Asian Americans, did not recall anything special about the discussion of Starrett, including the analysis of racial issues. See Interview by Interviewer A with Student No. 31 (Mar. 30, 1998) in Berkeley, Cal. (Asian-American female) (transcript on file with author); Interview by Interviewer $\mathrm{E}$ with Student No. 74 (Apr. 2, 1998) in Berkeley, Cal. (Asian-American male) (transcript on file with author).

226. Interview with Student No. 60 , supra note 189. For similar accounts of an easy moral consensus about the wrongfulness of racial discrimination, see Interview with Student No. 6, supra note 205 (school desegregation and Brown v. Board of Education); Interview with Student No. 30, supra note 183 (discrimination in accommodations and Katzenbach).

227. Interview with Student No. 103, supra note 225.

228. See Interview with Student No. 42, supra note 189.

229. Interview with Student No. 114, supra note 180. 
and ... that our class didn't have that many minorities to flesh out the issue." 230

One White woman complained that certain White students appointed themselves spokespeople for the missing students of color and silenced other points of view. In her view, these students might have been given a reality check if minority students had been in the class:

I've had classes in other universities where they were much more diverse and a lot of the times students of color were saying, "Of course people were concerned about property values. It's not that they're racist, it's that the system is racist." ... I grew up in the South, and I know White people have more of a guilt complex, and they don't ever feel like they can talk about the nuances of the issue because it makes them sound like being racist when in fact, if you were somehow able to be absolved of all accusations of racism, you could talk about it more clearly. ${ }^{231}$

She concluded that "all last semester, race was such a big issue. Here we were, these sort of guilty Whites that were in a class that a lot of us felt had not been created in a fair way." 232 As a result, discussion of racial issues was systematically distorted by the controversy surrounding the first-year student body's composition. Unable to confront the racial stratification in their own classrooms, students and faculty took refuge in the easy dualism of racism and innocence, of intolerant bigotry in the outside world and cosmopolitan liberalisin at Boalt.

iii. The Special Case of Criminal Law

The cases in which race and gender were most controversial arose in Criminal Law. Goetz, ${ }^{233}$ which addressed whether race is relevant to a person's reasonable fear for his or her safety, was particularly explosive because it forced students to address the meaning of wrongful discrimination, rather than to simply take for granted that race-related beliefs and actions are based on irrational animus. For many students, the discussion of this case was among the most meinorable in their law school careers. A Black man in the second-year class described the controversy that erupted over Goetz in his class as "the most egregious episode that I've seen in a discussion at Boalt Hall." As he recalled:

Student No. 57: [The professor] said, "I'll tell you something that happened in real life. I went to visit iny brother. He's like ine. He's about seventy years old. He's a little guy, and we're walking down the street, and we see skaters coming up, and they're thugs.

230. Interview with Student No. 96, supra note 222. See also Interview with Student No. 34, supra note 215 ("It may have been one of those days I think kind of abstractly how things might have been different if there were people of color in the room.").

231. Interview with Student No. 103, supra note 225.

232. Id.

233. 497 N.E.2d 41 (N.Y. 1986). 
They're making noise, and they're yelling profanities. So we decide that we better walk on the other side of the street because they're coming up. We're two little old men, and we'll walk on the other side of the street. As we do, they start to get near us, and they start to call us names, and then we walk off." "We took a detour" was his point. "Was it wrong to take a detour?"

Interviewer: The professor is asking that question?

Student No. 57: Yeah. ... It produced something that cannot be described as an argument but only as a diatribe about this biased man: "How he could make such a judgment? How did he know? What happened? What race?" He didn't bring up race until [a male student asked,] "What race were these people?" And [the professor] said, "They were African Americans," and that just launched a litany of attacks on this man .... It became then a discussion of should you look at people and make judgments. Obviously, this man made a judgment. My feeling was, he might be one of the greatest Criminal Law professors in the country, but he's also a little old man, and here was a man, I thought, being honest, going on a limb and saying, "You're not getting the point about subjective and objective, and I'll go out on a limb and say that this is how I'm feeling. I know it's wrong, but I'm going to tell you what was really going on." I thought this was exactly the reason why quality discussions don't come up. You go out on a limb and look what happens. ${ }^{234}$

Faculty faced controversy if they addressed racial issues, but they also ran the danger of being criticized for skirting those issues. An Asian-American student in another Criminal Law class expressed frustration at the professor's unwillingness to address race even when it was a salient feature of a case. Although she described her classmates as very diverse, given the overall composition of the first-year class, she found the discussion of race to be fleeting. She described how cases that implicated race were converted into hypotheticals that made the professor feel comfortable; he simply recast Blacks as Jews. ${ }^{235} \mathrm{~A}$ Latima in the first-year class described her frustrations with the classroom treatment of Goetz by the same professor: "I think [the professor] brought [race] up, but I think he brought it up very academically. I don't think he wanted us to focus on race. Actually ... [in the professor's hypothetical based on Goetz], the guy

234. Interview by Interviewer F with Student No. 57 (Apr. 24, 1998) in Berkeley, Cal. (Black male) (transcript on file with author).

235. See Interview by Interviewer C with Student No. 15 (Apr. 2, 1998) in Berkeley, Cal. (Asian-American female) (transcript on file with author). See also Interview with Student No. 60, supra note 189 (expecting lively discussion of race and the death penalty but being disappointed because "people didn't really want to say much, I think because it was a highly volatile issue"). 
wasn't Black, he was Jewish. That's what it was. Whenever there was a Black person, he would make the person Jewish because he's Jewish."236

Even though this student understood the professor's desire to make the discussion more academic by avoiding any "visceral reaction to having this prejudiced guy killing a Black person," she was "kind of offended" by the exclusion of race..$^{237}$ She recalled, however, that the students in the class did not challenge the professor on it, since "[f]or a lot of the students in my discussion, race didn't matter to them.... They thought that people were making a bigger deal of it than they should." woman who had taken Criminal Law with the same professor praised him for attempting to teach the nonracial aspects of Goetz:

I remember thinking "Good, because every other time I read about [Goetz], it is about the racial issue." I do remember people were kind of pissed, but he was teaching us his ideas. He's not claiming that this is the only point to the case. I do remember that it was void of the obvious racial issues. ${ }^{239}$

The question of self-defense for battered women in State v. Kelly ${ }^{240}$ led to provocative discussions about gender. Here, too, students sometimes found themselves battling with the professor. One White woman in the third-year class remembered that:

[The professor] was really trying to discredit Battered Woman's Syndrome and trying to ridicule it .... I remember speaking for at least twenty minutes in that class, fighting the professor. It was one of the classes I did that because I didn't feel it was fair to leave it up to my other friends or my female friends of color to have to go again battering [the professor's] opinions. ${ }^{241}$

One student recalled how both her male and female peers challenged the theoretical tone of another professor's discussion of the Kelly case. ${ }^{242}$ Still, forcing classmates to confront sensitive issues could exact a cost from outspoken students:

236. Interview by Interviewer C with Student No. 41 (Apr. 16, 1998) in Berkeley, Cal. (Latina female) (transcript on file with author).

237. Id.

238. Id.

239. Interview by Interviewer C with Student No. 134 (Mar. 19, 1998) in Berkeley, Cal. (White female) (transcript on file with author).

240. 478 A.2d 364 (N.J. 1984).

241. Interview with Student No. 8, supra note 190. Another student who took the class from the same professor reported a similar dynamic in which the professor "was often attacked by women in the class." Interview with Student No. 75, supra note 205. See also Interview with Student No. 45, supra note 195 (describing frustration in the professor's handling of the issue and praising the woinen in the class for educating male students about rape and domestic violence).

242. See Interview with Student No. 15, supra note 235. See also Interview with Student No. 41, supra note 236 (describing the class as "theoretical"). 
[T]here was a woman in my module [a small first-year class of approximately thirty students who all share the same assigned courses] that had done a lot of work with battered women. A woman of color .... [s] he was that student of color that, again, had a lot to say about things, but unfortunately was marginalized by students. ... I think she came out so strongly in one direction that it sort of put some fear in some people that really wanted to go in the other direction.... [S] he said something in such a way that it made majority students look pretty insensitive if you were to respond to it. $^{243}$

Students volunteered that rape cases also generated a great deal of discussion that marginalized and alienated female students. One White female reported:

My Criminal Law class was horrible, absolutely horrible. It was one of the worst classes I've ever had in my entire life. I felt discriminated against in that class almost every day that I walked in because my professor [not a regular member of the Boalt faculty] had a fascination with rape hypotheticals. Almost every single class involved a rape hypothetical at some point. Whether we were talking about accomplice liability or the actual crime of rape or something else, he brought it up. I addressed it with him, and I told him I was really offended by what he was doing and it was marginalizing half the class. I honestly believe women are at a disadvantage when talking about rape because it's something really different to a woman than it is to a man.... He just refused to hear my criticism at all. He was just like, "You're being irrational, and bad things happen to everybody. I've had students whose parents were murdered." I said, "Yeah, well, having that one student in two thousand whose parents have been murdered is really different than having fifty percent of your class all the time affected by what you're saying." 244

Another student noted that although her professor had received negative feedback in the form of female students walking out of his class when he talked about rape, he still "doesn't quite get it." 245 She believed that the problem stemmed from a failure to empathize with victims, some of whom might be sitting in the class:

243. Interview with Student No. 23, supra note 187. See also Interview with Student No. 74 supra note 225 ("I remember there were all women that spoke. And then they were all going for Kelly and saying, 'That poor woman. The guy deserves it. [unintelligible]' And then the professor tried to promote a discussion, like try to get something out of the other side, and nobody spoke.").

244. Interview with Student No. 90, supra note 188. See also Interview with Student No. 9, supra note 223 ("I don't remember the subject matter, but all of the cases were all about scxualized violence. I do remember a couple of women that really spoke out against it and were upset that all the cases were in that vein.").

245. Interview with Student No. 45, supra note 195. 
I think it's important when you're going to talk about an issue like rape or domestic violence to realize that probably a third of the class has had some sort of direct experience with this. ... Statistically, you can't have a class of thirty people and half of them be women and not have some of them raped. ... There just wasn't a basic understanding of how pervasive this is and how much it's related to misogyny. ${ }^{246}$

In other interviews, students remarked on the intensity of the debate among their peers, with fierce discussion along gender lines leading to some opinions being stifled as politically imcorrect. ${ }^{247}$ In another instance, a White male in the upper division described how a peer had triggered a discussion that "got a little bit ugly" and how this influenced his own willingness to speak:

It was in the section about rape, and one student said something .... that was somewhat unremarkable to me, so I didn't pay a lot of attention then, but somebody else that had been a rape victim interpreted that as being that it was her fault under certain circumstances. I don't think he meant it that way, but looking back and adding to the fact that for somebody it was already a sore spot, it had the potential of being taken that way.... It was an unfortunate situation that tends to come up when a real painful topic like that was being discussed. It's an issue that I don't like to discuss myself very much because I know what I'm thinking, but I have to be really, really careful about how I word everything because... there's so many things that can be taken so many ways. $^{248}$

As the recollections of Criminal Law show, these cases resulted in the most intense and memorable discussions. At the same time, though, the class debate had the greatest potential to become oppressive and polarizing. Ideally, students would engage in a lively and provocative exchange that forced them to confront the sometimes treacherous terrain of race and gender. At worst, though, students retreated into silence for fear of being ostracized and labeled.

iv. The Implications of the Vignettes for Powell's Pedagogy of Diversity

The range of responses elicited by the vignettes prompts an interesting question for those who share Powell's vision of diversity in legal education: why did cases that implicate race and gender issues result in such

246. Id.

247. See Interview with Student No. 71, supra note 180 (expressing her agreement with another classmate that "a lot of people had been silenced" during a discussion on rape due to a "PC [politically correct] mentality"); Interview with Student No. 74, supra note 225 (stating belief that silencing conservative males was "reverse discrimination").

248. Interview with Student No. 47, supra note 180. See also Interview with Student No. 51, supra note 179 (describing general discomfort with discussing contentious issues such as rape). 
varied classroom experiences? In some instances, the ahistorical and decontextualized nature of doctrinal analysis effectively suppressed these concerns. Gender was easily abstracted out of Korman v. Mallin because the case made no reference to how the women's movement and the push to control one's own body influenced the doctrine of informed consent. Yet, even in Katzenbach, when racial discrimination motivated congressional action, the relevance of race could be minimized by treating the decision as just another instance of Commerce Clause jurisprudence.

When the relevance of race was acknowledged, as with Starrett City, faculty and students often simply opined that racial discrimination was bad without undertaking the challenges of analyzing the roots of racism, its different manifestations, or the policy solutions that might be effective. The extent to which race or gender emerged often depended on the professor. Baby M., for example, could be taught as a case about the degree to which some goods can be commodified in the free market, or it could be linked to the special nature of motherhood and the emotional attachments that result. Similarly, race could be a highly salient or merely occasional theme in Property. While some students appreciated efforts to accentuate race and gender, ${ }^{249}$ others feared that they were not getting a standardized, black letter law course. Although students expressed annoyance with professors who elevated philosophical or economic theory over doctrine, they did not view these abstract approaches as a threat to getting a good legal education. Presumably, these theoretical perspectives were a sufficiently pervasive feature of the curriculum to win grudging respect, while race and gender were unusual enough to remain suspect.

Criminal Law was the one course in which abstract principles seldom succeeded in masking the relevance of race and gender. Interestingly, the Criminal Law professors were regularly criticized for being too theoretical, yet their efforts rarely prevented students from addressing the social, political, and emotional underpinnings of the cases. The fundamental invasions of the person at stake in the course made it nearly impossible to avoid traits central in defining personhood. Very often race and gender played an important part in defining the relationships of subordination and aggression at the heart of a criminal act. As a result, these cases evoked the most vivid recollections of heated discussions about race and gender. ${ }^{250}$

249. See, e.g., Interview with Student No. 75, supra note 205.

250. A full discussion of the relationship between acts of violence and personal identity is beyond the scope of this paper. For a recent exploration of these issues by a Boalt professor of Criminal Law, see Angela P. Harris, Gender, Violence, Race, and Criminal Justice, 52 STAN. L. REv. 777, 781-92 (2000). 


\section{Contact with Faculty}

Strong faculty-student relations can help to build an inclusive institution. Although this guidance and support can have a powerful influence on a student's educational experience, most Boalt students did not have faculty mentors. In fact, when asked whether they had a mentor, only two students, both White women, replied that they did. ${ }^{251} \mathrm{~A}$ few students answered the question by stating that they had gone to see faculty during office hours. ${ }^{252}$ Most students, however, responded that they had no mentors, and indeed, one twenty-five-year-old White male in his third year of law study was so surprised by the question that he replied, "I don't know what that [a mentoring relationship] means. ${ }^{.253}$ In explaining why they did not have a mentor, most students cited the inaccessibility of some or all of the faculty. ${ }^{254} \mathrm{~A}$ White woman in the third-year class noted that faculty limited their interest in students to the few stars in the class, such as those who "are going to clerk for Ninth Circuit judges and remind them of them."255 Several also cited the lack of minority and women faculty in their answers. ${ }^{256}$ A substantial minority blamed themselves, however. ${ }^{257}$

\section{a. Reasons for the Lack of Mentoring Relationships}

Students who blamed themselves consistently stated that they did not have a mentor because they were not that type of person or because they

251. See Interview with Student No. 66, supra note 181; Interview with Student No. 77 , supra note 218.

252. See Interview with Student No. 46, supra note 212; Interview with Student No. 49, supra note 212; Interview with Student No. 59, supra note 189; Interview with Student No. 62, supra note 198; Interview by Interviewer G with Student No. 101 (Mar. 19, 1998) in Berkeley, Cal. (White male) (transcript on file with author); Interview with Student No. 103, supra note 225.

253. Interview by Interviewer B with Student No. 28 in Berkeley, Cal. (Mar. 11, 1998) (White male) (transcript on file with author).

254. See Interview with Student No. 23, supra note 187; Interview with Student No. 34, supra note 215; Interview by Interviewer E with Student No. 35 (Apr. 22, 1998) in Berkeley, Cal. (White male) (transcript on file with author); Interview with Student No. 37, supra note 192; Interview with Student No. 39, supra note 205; Interview with Student No. 45, supra note 195; Interview with Student No. 47, supra note 180; Interview with Student No. 52, supra note 196; Interview with Student No. 56, supra note 184; Interview with Student No. 65, supra note 199; Interview by Interviewer D with Student No. 70 (Apr. 17, 1998) in Berkeley, Cal. (White female) (transcript on file with author); Interview with Student No. 71, supra note 180; Interview by Interviewer A with Student No. 73 (Mar. 30, 1998) in Berkeley, Cal. (Asian-American female) (transcript on file with author); Interview with Student No. 75, supra note 205; Interview with Student No. 90, supra note 188; Interview with Student No. 96, supra note 222; Interview with Student No. 115, supra note 180; Interview with Student No. 134, supra note 239.

255. Interview with Student No. 45, supra note 195.

256. See Interview with Student No. 15, supra note 235; Interview with Student No. 23, supra note 187; Interview with Student No. 30, supra note 183; Interview with Student No. 34, supra note 215; Interview with Student No. 51, supra note 179.

257. See, e.g., Interview with Student No. 43, supra note 185; Interview with Student No. 60 , supra note 189; Interview with Student No. 61, supra note 205; Interview with Student No. 74, supra note 225; Interview with Student No. 120, supra note 182. 
did not like to "brown nose."258 Most students did not pursue this statement further, although a few linked their failure to seek out their professors to their lack of interest in law study. In at least some instances, students who attributed their lack of a mentor to their own personalities also expressed doubts that this explanation was entirely satisfactory. For example, one Asian male immigrant student who offered this rationale went on to say that soune professors had treated him dismissively because of his accented English. ${ }^{259}$

Those who focused on the faculty in explaining the lack of a mentor observed that faculty were inore focused on research than teaching, that they were extremely busy and therefore limited student contact, and that they lacked the social skills to interact effectively with students. One student described how "I came here and I went to go see a professor, and 1 saw a little sign on the door that said "Wednesdays, one to three." other student criticized the faculty for their inability to relate to students, citing practitioners as inore "human" and "less arrogant" than professors:

I have been really appalled at the poor interpersonal skills that professors have. I just find their behavior really unacceptable and just totally obnoxious. I'm not saying all of them, but many professors I have seen during office hours have been rude, rushed, just seemed bored. I know that academia rewards professors for not liking to teach, and it shows. The best professors that I have had are the ones that are new, practitioners, or from [another less highlyranked Bay Area law school]. ${ }^{261}$

Some students distinguished among faculty based on their personality, ${ }^{262}$

258. See, e.g., Interview with Student No. 6, supra note 205 ("I'm not the kind of person that goes to professors' office hours constantly ..."); Interview with Student No. 15, supra note 235 (stating that she was "not the type" to seek out professors); Interview with Student No. 28, supra note 253 ("people were going up there to kiss the professor's butt and I wasn't going to do that"); Interview with Student No. 42, supra note 189 (blaming both her lack of initiative and a bierarchical system that "makes me feel like a child"); Interview with Student No. 43, supra note 223 ("I personally don't do that kind of stuff...."); Interview with Student No. 60, supra note 189 ("That's not really my style."); Interview with Student No. 61, supra note 205 ("[T]hat's my own personal thing."); Interview by Interviewer E with Student No. 63 (Apr. 24, 1998) in Berkeley, Cal. (Latino male) (transcript on file with author) ("1t wasn't me saying, 'Oh, I've gotta go see a professor who I really like and brown nose."'); Interview with Student No. 120, supra note 182 (the failure to develop mentoring relationships was "through my own fault").

259. See Interview with Student No. 74, supra note 225.

260. Interview with Student No. 37, supra note 192.

261. Interview with Student No. 39, supra note 205; see also Interview with Student No. 37, supra note 192 (deciding to take classes with nontenured faculty thinking they would "be more interested in teaehing and more accessible").

262. See Interview with Student No. 37, supra note 192; Interview with Student No. 39, supra note 205; Interview with Student No. 45, supra note 195; Interview with Student No. 58, supra note 205; Interview with Student No. 71, supra note 180. 
their age, ${ }^{263}$ their ideology, ${ }^{264}$ or their status as adjuncts or lecturers. ${ }^{265}$ Particularly striking were the disparate perceptions of professors' accessibility to and interest in students. One student described a member of the faculty as "absolutely inaccessible in the large classes. He makes it very clear he doesn't want to see anyone, and you talk to him via e-mail. He's more comfortable with e-mail. He's just completely detached."266 By contrast, another student described the warmth and concern of a female professor as key to his willingness to seek her out for advice: "[T]he fact ... that she so clearly cares about ... helping me find the right path for myself, it really touches me."267

\section{b. The Relevance of Race and Gender to Mentoring Relationships}

Although some students indicated that race and gender were irrelevant to mentoring relationships, ${ }^{268}$ others thought they did have an impact. One White woman in the first-year class acknowledged that gender would make a difference in her choice of a mentor, saying, "When I think about having a close relationship with a professor, I think it will probably be a woman professor. ... I'm definitely aware of that." ${ }^{\text {"269 }}$ Another White woman in the upper division explained why women made better mentors than men:

Women professors just seem more human. They just seem to care more about students. "Am I getting through to you? Am I being nice to you? Are you having a good day?" .... I don't know if that's dumb or not, but that's how I perceive it, and I go to them. If there was a male professor that was like that, I'd probably go to him, too. ${ }^{270}$

263. See Interview with Student No. 45, supra note 195; Interview with Student No. 75, supra note 205.

264. See Interview with Student No. 35, supra note 254; Interview with Student No. 73, supra note 254; Interview with Student No. 75, supra note 205.

265. See Interview with Student No. 37, supra note 192; Interview by Interviewer B with Student No. 38 (Apr. 17, 1998) in Berkeley, Cal. (White female) (transcript on file with author); Interview with Student No. 39, supra note 205; Interview with Student No. 45, supra note 195; Interview with Student No. 58, supra note 205; Interview with Student No. 96, supra note 222.

266. Interview with Student No. 56, supra note 184. See also Interview with Student No. 77, supra note 218 (describing the same professor as so "standoffish" that she felt more comfortable communicating with him by e-mail than in person).

267. Interview with Student No. 65, supra note 199.

268. See, e.g., Interview with Student No. 9, supra note 223; Interview by Interviewer C with Student No. 36 (Apr. 23, 1998) in Berkleley, Cal. (White male) (transcript on file with author); Interview with Student No. 46, supra note 212; Interview with Student No. 49, supra note 212; Interview with Student No. 70, supra note 254; 1nterview with Student No. 74, supra note 225; Interview with Student No. 79, supra note 212; Interview with Student No. 120, supra note 182; Interview with Student No. 133, supra note 182.

269. Interview with Student No. 34, supra note 215. See also Interview with Student No. 45, supra note 195 ("It was useful in developing a relationship with her that she's a woman.").

270. Interview with Student No. 134, supra note 239. See also Interview with Student No. 56, supra note 184 (White male saying "I felt more comfortable with my women professors."). 
However, some students who acted on the assumption that women would be better mentors than men were disappointed:

It's difficult in terms of mentoring. I want to say that some of my female professors have been more responsive, but I don't know that that's really true.... I don't know why that is. It may just be my experience.... A lot of the female professors seemed really busy, particularly the untenured ones. They've got a lot going on, and they're in high demand, and they have a lot of stuff to do, so it's a little more difficult. ${ }^{271}$

Another student concurred that the high demand for female professors interfered with their ability to make time for students. She described a woman on the faculty as

one of the nicest professors, so she has a million students following her around all day .... Given that, [the mentoring relationship]'s been limited. Every time I talk to her, it's been rushed. If she had more time, she'd be more of a mentor. But she's the closest thing that I have. ${ }^{272}$

Not as many students addressed race as a factor in the mentoring relationship. An Asian-American woman in the first-year class stated that she would be more likely to have a mentoring relationship, if there were someone like her on the faculty, because during her undergraduate years, she "would just gravitate more to the Asian-American professor" because she "would start with the assumption that they were aware of Asian-American issues and things like that. That's automatically something that I could talk to them about. Whereas with another prof, I don't really know where to start." 273 A Latina in the first-year class was unsure about the subtle impact of race on her ability to find a mentor, noting that her dissatisfaction with the predominantly White, male faculty "may have an effect [on] how much I want to interact with the person."274

Another Latino student in the first-year class expressed a similar sense of uncertainty, partly because he had never had a Latino professor, though he did go on to add that "there are people I know from my hometown, Hispanic people, that would probably feel more comfortable having a relationship with a Hispanic professor, just because there's this sense of the shared identity ...."275 Like him, several participants noted that they could

271. Interview with Student No. 75, supra note 205. See also Interview with Student No. 39. supra note 205 (explaining that he can feel a bond with women professors, but he finds the relationship with male professors "[l]ess love and hate").

272. Interview with Student No. I34, supra note 239.

273. Interview with Student No. I31, supra note 212. See also Interview with Student No. 34, supra note 2I5 ("I think that if I were a person of color, I would definitely be looking for someone of color. It seems like I've noticed that with students around me.").

274. Interview with Student No. 51, supra note 179.

275. Interview with Student No. 30, supra note 183. 
not gauge the impact of race on mentoring because of the lack of people of color on the faculty. A White male im the third-year class put it most succinctly: "Race, come on, let's face it. There hasn't been much racial diversity in my professors. So that hasn't even become an issue. Basically, with the exception of one professor, all my professors have been White."276

One Black student who expected a minority professor to be especially helpful was disappointed by his experience:

[The professor] gave out a practice exam, and I went home and as a hard-core student, wanting to do well, I wrote an answer and then I went to his office hours. Mind you, he had a very stringent schedule, and you had to schedule it a week before and what not. I go through all his hoops, and I get there and he's like, "I haven't discussed that in lecture yet, and I'm going to discuss it today in lecture, so I'm not going to talk to you about it. And furthernore, I'm not going to look through your answer." It was shocking to me because it wasn't that I was asking him to build a bridge for me, but I did not want to see him standing on the other side of the river while I'm jumping and just watching me fall in the water on the other side. ${ }^{277}$

However, this student also recognized that faculty of color faced unique burdens that interfered with their ability to offer personal attention and guidance. Specifically, these faculty were often torn between their professional responsibilities and their desire to help and mentor those in the community. ${ }^{278}$

\section{c. The Roots of the Divide Between Faculty and Students}

The students' cominents about mentoring at Boalt corroborate the findings in MacLachlan's study of graduate students at Berkeley. ${ }^{279}$ Students often find themselves intimidated by a star system that seems to exclude them, and rather than blame the faculty, they regularly blame themselves for a lack of imitiative. Consistent with MacLachlan's fimdings about Berkeley faculty in other graduate programs, Boalt professors

276. Interview with Student No. 56, supra note 184. See also Interview with Student No. 62, supra note 198 (second-year Black male) ("I didn't have any male non-White professors except for one White woman professor."); Interview with Student No. 66, supra note 181 (second-year White female) ("It's hard for me to tell because l'm White and most of them [the professors] were White."); Interview with Student No. 70, supra note 254 (second-year White female) ("I haven't taken any classes, I don't think, with a minority lecturer, depending on how you define minorities I suppose."); Interview with Student No. 103, supra note 225 (first-year White female) ("[A]ll my professors so far have been White men, with the exception of [a White woman]. 1 don't really have any basis for comparison."); Interview with Student No. 114, supra note 180 (first-year White male) ("All the professors I've had are White. I only had one female professor, and that's this semester. I don't think I'm in a position to say [what effect race and gender have on mentoring relationships]. I would just be guessing.").

277. Interview with Student No. 23, supra note 187.

278. See id.

279. See MacLachlan, supra note 151. 
frequently seem preoccupied with research, socially distant, and largely inaccessible. As a result, students must learn to survive on their own, largely without faculty guidance. Indeed, it is impossible to assess whether race and gender differences independently contribute to the substantial gap between students and their professors, not only because of the lack of faculty diversity but also because of the absence of mentoring relationships of any kind.

The law school presents some unique complications for the mentoring relationship because the professional lives of faculty and students diverge significantly. In doctoral programs, students typically are preparing for the same lives that professors currently lead. At Boalt, though, the vast majority of each class will wind up practicing law rather than teaching it. Students can successfully obtain a job in practice with relatively little direct support from the faculty. A law student with good grades and strong extracurricular activities will probably obtain several offers of employment. Because grades are awarded using randomly assigned numbers rather than by students' names, faculty cannot favor their protégés, and students who never come to office hours can win the highest marks in the class. Professors may be listed as references on a student's résumé, but law firms often do not bother to call. Only students seeking scarce jobs in public interest, prestigious judicial clerkships, or highly competitive teaching jobs must worry about cultivating close relationships with the faculty.

Moreover, many professors have relatively little contact with the lives that students will lead in practice. Faculty often arrive with an interdisciplinary, theoretical approach to the law, rather than with an interest in doctrinal analysis. Indeed, some faculty at the law school have $\mathrm{Ph} . \mathrm{D}$. degrees in other disciplines and do not even have a law degree. ${ }^{280}$ At Boalt, many professors are hired shortly after they graduate from law school, so their experience with law practice is quite limited. Critics have assailed the growing divergence between legal academia and the legal profession, arguing that the faculty no longer address the interests, concerns, and obligations of practicing attorneys. ${ }^{281}$ However, little has been said about how this increasing disparity affects mentoring relationships between students and faculty. Students may not need much in the way of faculty support to get a job, and they may also find little in the way of faculty guidance about how to build a career. Interestingly, a substantial number of students singled out

280. See, e.g., Boalt Hall School of Law, University of California, Berkeley, Boalt HALL'S 1997-98 ADMISSIONS CATALOG 10-12 (1997) (listing faculty and their degrees; of fifty-thrce faculty, not including emeriti, twelve had no law degree). These faculty are primarily responsible for overseeing a Ph.D. program in Jurisprudence and Social Policy, but they teach some courses in the regular law school curriculum, are on the law school salary scale, and participate fully in law school governance.

281. See, e.g., Harry T. Edwards, The Growing Disjunction Between Legal Education and the Legal Profession, 91 MicH. L. REv. 34 (1992). 
practitioners who taught as adjuncts or lecturers as prime sources of information and advice. While a heavy reliance on "free-lance faculty" has been criticized as diluting the educational experience, ${ }^{282}$ these adjuncts and lecturers also may help to fill the gap between theoretically oriented professors and practically oriented students, a gap that seems to be widening along with the divide between the academy and the profession. Indeed, the gap is already so broad that faculty-student mentoring relations are clearly the exception rather than the rule.

\section{Study Groups}

Although students had distinctive views about the nature of their classroom experience, when it came to study groups, they shared a remarkably uniform vision. An overwhelming number of participants reported that if they were in a study group, it focused on the black letter law needed to perform well on examinations. One student remarked that all students were really the same: "We just want to know what we need to know for the test." This student added that "I think in study groups, people are really, what's the word I'm looking for, mercenary?"283 Only nime students indicated that their group discussed policy issues, and some of these students stated that they focused on these concerns because the professor used a take-home paper format that rewarded analysis of law and policy. ${ }^{284}$ In short, whatever their vision of the nature of law and how it should be taught, at examination time, nearly all students understood that they would be recognized for mastering and manipulating abstract rules of law.

\section{a. Race, Gender and the Formation of Study Groups}

A substantial number of students chose to study alone. ${ }^{285}$ Some attributed their decision to their personality or their dislike of studying. ${ }^{286}$ Others

282. See Association of AMERICAN LAW Schools, 1999 HaNdBooK § 6-5(d), at 32 (1999).

283. Interview with Student No. 120, supra note 182.

284. See Interview with Student No. 23, supra note 187; Interview with Student No. 39, supra note 205; Interview with Student No. 50, supra note 205; Interview with Student No. 51, supra note 179; Interview with Student No. 53, supra note 195; Interview with Student No. 58, supra note 205; Interview with Student No. 75, supra note 205; Interview with Student No. 90, supra note 188; Interview with Student No. 115, supra note 180.

285. See Interview with Student No. 15, supra note 235; Interview with Student No. 28, supra note 253; Interview with Student No. 30, supra note 183; Interview with Student No. 38, supra note 265; Interview with Student No. 41, supra note 236; Interview with Student No. 42, supra note 189; Interview with Student No. 47, supra note 180; Interview with Student No. 52, supra note 196; Interview with Student No. 59, supra note 189; Interview with Student No. 61, supra note 205; Interview with Student No. 65, supra note 199; Interview with Student No. 66, supra note 181; Interview with Student No. 69, supra note 186; Interview with Student No. 73, supra note 254; Interview with Student No. 80, supra note 189; Interview with Student No. 133, supra note 182; Interview with Student No. 134, supra note 239.

286. See, e.g., Interview with Student No. 30 , supra note 183 ("I guess a Iot of the reason is that I don't study all that much. So when you go into a study group, they want to meet at a certain time, and I don't want to be confined by what they do."); Interview with Student No. 47, supra note 180 ("I didn't 
thought that working on their own was more efficient. ${ }^{287}$ Four women had wanted to study with a group but were not invited to join one. Two were White, one was Latina, and one was Asian American. Both White women offered explanations that focused on their personal attributes. ${ }^{288}$ The two women of color did not blame themselves. One could not understand why she did not end up in a study group, while the other thought a competitive, isolating law school environment was responsible. ${ }^{289}$

When study groups formed, they almost invariably included students who were in the same module and hence shared the same class schedule. ${ }^{290}$ About two-thirds of the groups included both men and women, and about half included students of different races and ethnicities. ${ }^{291}$ Only five students reported studying in a group that was homogeneous in terms of race and gender. These students were all White; three were men and two were women. ${ }^{292}$ Because Whites far outnumber any other group at Boalt and because the sample size was small, not too much can be read into this finding.

Twelve students, six men and six women, reported that they studied in a racially homogeneous group that included men and women. In some instances, the groups were mixed by gender because they included only one

do any serious studying my first year."); Interview with Student No. 61, supra note 205 (did not study with a group because of "individualistic" nature); Interview with Student No. 69, stupra note 186 ("kind of a loner"); Interview with Student No. 133, supra note 182 (did not like to study so did not join a group). See also Interview with Student No. 96, supra note 222 (usually not in a study group because she was a "procrastinator");

287. See, e.g., Interview with Student No. 28, supra note 253 ("I thought that [study groups] were a complete waste of time and that they were really annoying. I could just be a lot more efficient with my time doing it myself."); Interview with Student No. 38, supra note 265 ("Reading the material on my own and processing it on my own, that is the best way I've found to learn ...."); Interview with Student No. 65, supra note 199 ("I tried a study group for the first year during the first two weeks, and we found out we really liked to get together and talk, but we didn't like to talk about cases, and we had radically different styles of studying, so it didn't really work.").

288. See Interview with Student No. 42, supra note 189 (White woman felt she was excluded because she was perceived as too assertive); Interview with Student No. 134, supra note 239 (White woman thought that her grades were not good enough to get her invited to participate in a study group).

289. See Interview with Student No. 41, supra note 236 (Latina female's plans to join a study group did not materialize); Interview with Student No. 73, supra note 254 (Asian-Ameriean female found it difficult to join a study group in an intense law school setting).

290. The following twenty-nine students reported that their study partners were in the same classes or module: No. 6, No. 8, No. 33 , No. 34 , No. 35 , No. 36 , No. 39 , No. 43 , No. 45 , No. 46 , No. 49 , No. 50 , No. 51 , No. 55 , No. 57 , No. 58 , No. 60 , No. 62 , No. 63 , No. 68 , No. 70 , No. 71 , No. 75 , No. 84 , No. 90 , No. 101 , No. 115 , No. 120 , and No. 131.

291. Five students made ambiguous remarks about the composition of their study groups, and their responses are excluded from this analysis. They were No. 31, No. 34, No. 43, No. 63, and No. 77 .

292. See Interview with Student No. 9, supra note 223 (White male); Interview with Student No. 26, supra note 205 (White female); Interview with Student No. 37, supra note 192 (White male) (transfer student who studied in homogeneous group during first year at another institution); Interview with Student No. 75, supra note 205 (White female); Interview with Student No. 101, supra note 252 (White male). 
man or one woman. ${ }^{293}$ All the students in the racially homogenous groups were White or Asian American with the exception of one Black student. ${ }^{294}$ This Black student joined a racially homogenous study group only because he felt excluded by classmates in his module. As he explained, "I wasn't going to invite myself to participate in these study groups, and I think they were being developed right around me. I just wasn't being invited to participate in most of the groups." He refused to speculate on why he was excluded because he did not want to become angry: "Why would you make a study group around me and not include me? Again, you're making some assessment of what value I can contribute to it."295

Six students-four White women, one Asian-American woman, and one White man-reported studying in a group that was all male or all female but included members of diverse racial and ethnic backgrounds. ${ }^{296}$ Three of the six indicated that the group consisted of Whites and Asian Americans. ${ }^{297}$ In some instances, the group was racially diverse only because it contained one non-White member, typically an Asian-American student. ${ }^{298}$ Again, however, not too much can be read into this finding given the small sample size and the fact that the two largest racial groups at Berkeley are Whites and Asian Americans. Twelve students, seven men and five women, stated that their study groups included both men and women and members from a range of racial and ethnic backgrounds. A bare majority of the students were White, and only one was Asian American. By contrast, just under one-third were Black or Latino. ${ }^{299}$ Nearly

293. See, e.g., Interview with Student No. 63, supra note 258; Interview with Student No. 70 , supra note 254; Interview with Student No. 131, supra note 212.

294. Of the 12 students, seven were White, four were Asian American, and one was Black. See Interview with No. 6, supra note 205 (Asian-American male); Interview with No. 23, supra note 187 (Black male); Interview with Student No. 39, supra note 205 (White male); Interview with Student No. 45, supra note 195 (White female) (later "ditched the guys"); Interview with Student No. 49, supra note 212 (White female); Interview with Student No. 53, supra note 195 (White male); Interview with Student No. 55 (Mar. 18, 1998) in Berkeley, Cal. (White female) (transcript on file with author); Interview with Student No. 56, supra note 184 (White male) (saying he was "not a big study group person" and sometimes studied with a group of all White males); Interview with Student No. 71, supra note 180 (White female); Interview with Student No. 74, supra note 225 (Asian-American male); Interview with Student No. 79, supra note 212 (Asian-American female); Interview with Student No. 131, supra note 212 (Asian-American female).

295. Interview with Student No. 23, supra note 187.

296. See Interview with Student No. 8, supra note 190 (White female); Interview with Student No. 36, supra note 268 (White male); Interview with Student No. 58, supra note 205 (Asian-American female); Interview with Student No. 60, supra note 189 (White female); Interview with Student No. 90 , supra note 188 (White female); Interview with Student No. 115, supra note 180 (White female).

297. See Interview with Student No. 36, supra note 268 (White male); Interview with Student No. 60 , supra note 189 (White female); Interview with Student No. 90, supra note 188 (White female).

298. See, e.g. , Interview with Student No. 70, supra note 254; Interview with Student No. 84 , supra note 205; Interview with Student No. 120, supra note 182.

299. Of the twelve students, seven were White, three were Black, one was Asian American, and one was Latina. See Interview with Student No. 33, supra note 178 (White male); Interview with Student No. 35, supra note 254 (White male); Interview with Student No. 46, supra note 212 (White 
half of the groups consisted of White and Asian-American students, ${ }^{300}$ but two students remarked that their study partners or classmates in their small section resembled an ad for the United Colors of Benetton. ${ }^{301}$

\section{b. The Limited Role of Study Groups in Promoting a Pedagogy of Diversity}

Despite the small sample size, these results seem consistent with Orfield and Whitla's finding that almost half of the law students at Harvard and Michigan rarely or never study with students of another race, even though their classmates are diverse. ${ }^{302}$ A great many students either study alone or with students of the same race. As a result, racial and ethnic diversity does not affect their review of course materials. However, the findings here also expand on Orfield and Whitla's work by offering some preliminary insights into why study groups are relatively homogeneous. Apparently, the task orientation of these groups is learning black letter law, not reflecting on policy, theory, or personal experiences. In this setting, race and ethnicity may seem largely irrelevant to the task at hand, so students do not actively seek out diverse study groups. Instead, they select classmates from their module, and in a world in which White students constitute a clear majority, many of the groups will be racially homogeneous. The topic of the course, the racial make-up of students in the class, and the structure of the examination format can affect students' choices about study groups. One participant, for instance, reported that she studied in a racially homogeneous group for Constitutional Law but in a racially diverse group for Race and American Law. ${ }^{303}$ Students in the majority can opt for racial homogeneity, but minority students are dependent on interracial contact to form groups that review and reinforce classroom lessons. As a result, some students of color may feel left out because they are not asked to join a group, or they will be absorbed into groups in which they are the lone non-White. Their situation stands in marked contrast to that of women who can and do seek out the comfort of all-female study groups.

female); Interview with Student No. 50, supra note 205 (Black male); Interview with Student No. 51, supra note 179 (Latina female); Interview with Student No. 57, supra note 234 (Black male); Interview with Student No. 62, supra note 198 (Black male); Interview with Student No. 68, supra note 205 (White male); Interview with Student No. 70, supra note 254 (White female); Interview with Studcnt No. 84, supra note 205 (Asian-American female); Interview with Student No. 103, supra note 225 (White female); Interview with Student No. 120, supra note 182 (White male).

300. See Interview with Student No. 33, supra note 178 (White male); Intcrview with Student No. 46, supra note 212 (White female); Interview with Student No. 70, supra note 254 (White female); Interview with Student No. 84, supra note 205 (Asian-American female); Interview with Student No. 120 , supra note 182 (White male).

301. See Interview with Student No. 55, supra note 294; Interview with Student No. 57, supra note 234.

302. See Orfield and Whitla, supra note 124.

303. See Interview with Student No. 45, supra note 195. 
It is interesting to note that when policy discussions took place, they generally happened in groups that were heterogeneous in terms of race, gender, or both. Of the groups discussing policy, three of the students described racially homogeneous groups that included men and women, ${ }^{304}$ three described racially diverse groups that were homogeneous with respect to gender, ${ }^{305}$ and two described groups that were racially diverse and included both men and women. ${ }^{306}$ Only one student in a group that was homogeneous in terms of race and gender reported talking about policy issues; her group consisted of all White women. ${ }^{307}$ Though the sample size is too sinall to reach defimitive conclusions, diversity did appear to facilitate an exchange of ideas that transcended memorization and manipulation of black letter law.

\section{Extracurricular Activities}

Although a number of students chose to study alone, only a handful reported that they did not participate in any law school activities. Most of these students said that their only outside activity involved sports. ${ }^{308}$ Of those students who were involved in some law school activities, there was a split between those who participated primarily for résumé value and those who participated mainly to build a sense of professional or personal identity. One student explained how the distinction affected his choices:

[T] he first-year [activities] I did because I wanted to get involved.... I figured it would be a good way to meet people and get soine practical experience, at least in terms of the Hopi and the East Bay Workers' Rights Clinic. I just wanted to see what they would be like, and I ended up really enjoying both of those. Just to meet people is basically the reason I joined Technology Journal and to throw something on a résumé. CLR [California Law Review], even after I got accepted, was something I seriously considered not doing, but I wanted to do a clerkship. I talked to a couple of people that said it was really important for that, so I just figured, whatever, play the game. ${ }^{309}$

304. See Interview with Student No. 23, supra note 187; Interview with Student No. 39, supra note 205; Interview with Student No. 53, supra note 195.

305. See Interview with Student No. 58, supra note 205; Interview with Student No. 90, supra note 188; Interview with Student No. 115, supra note 180.

306. See Interview with Student No. 50, supra note 205; Interview with Student No. 51, supra note 179.

307. See Interview with Student No. 75, supra note 205.

308. See, e.g., Interview with Student No. 30, supra note 183 (Latino male) (basketball); Interview with Student No. 31, supra note 225 (Asian-American female) (dance); Interview with Student No. 36, supra note 268 (White male) (no extracurricular activities); Interview with Student No. 101, supra note 252 (White male) (basketball).

309. Interview with Student No. 28, supra note 253 (White male). See also Interview with Student No. 8, supra note 190 (White female) (distinguishing between joining California Law Review for professional reasons, while joining Berkeley Women's Law Journal for social reasons); Interview with 
Although some students indicated that they were building a résumé instead of an identity, ${ }^{310}$ there were others who saw their activities as integral to their law school experience. A White female called her activities "where I found fulfillment in law school" and explained "I would have gone insane if I had just been focused on the fulfillment in course work."311 A Latino male in the first-year class said that his involvement in the Coalition for a Diversified Faculty and Student Body (CDF/SB), La Raza Law Students Association, the Student Equal Educational Opportunity Initiative (an effort to reinstate affirmative action through the initiative process that ultimately failed), and the Bay Area Police Watch were "definitely social support for me because there's a very big, black hole that's sucking a lot out of me." He found that the "political nourishment is also spiritual." 312

\section{a. Race, Gender and the Nature of Organizational Involvement}

The distinction between credentialing and identity-building influenced the role of race and gender in shaping students' organizational commitments. In two instances, male students of color shied away from activities that would identify then racially. A Latino student thought that racial and ethnic organizations served sone useful purposes, but he was ambivalent about getting involved in then1. ${ }^{313}$ An Asian immigrant student avoided the Asian Law Journal because it was "too racially oriented. . . . They would just have their little heads in the racial issues, and I didn't think it was necessary. I didn't want to associate with them." ${ }^{314}$ On the other hand, a racially mixed man of Asian ancestry expressed disappointment that the Asian Pacific American Law Students Association is "largely an organization on paper.... It does absolutely nothing. It does nothing politically, it does nothing really socially." ${ }^{315}$ Similarly, an Asian-American wonian in her first year of law study joined the Asian Law Journal, expecting to find her closest friends there. Unexpectedly, she found that her friendships with a racially diverse group were formed outside the journal,

Student No. 69, supra note 186 (White female) (describing her activities as mainly undertaken for their résumé value).

310. Two other students described their membership on California Law Review as undertaken for résumé value. See Interview with Student No. 8, supra note 190; Interview with Student No. 133, supra note 182; see also Interview with Student No. 60, supra note 189 (attributing her participation on the Berkeley Technology Law Journal to a class requirement).

311. Interview with Student No. 8, supra note 190.

312. Interview with Student No. 80, supra note 189; see also Interview with Student No. 41, supra note 236 (Latina female in the first-year class) (describing importance of her involvement in La Raza Law Students Association, Workers' Rights Clinic, and CDF/SB).

313. See Interview with Student No. 63, supra note 258.

314. Interview with Student No. 74, supra note 225.

315. Interview with Student No. 6, supra note 205. 
an experience that she came to believe would better prepare her for life in the "real world." 316

Some students mentioned that organizations gave them the opportunity to build important social relationships across boundaries of race, ethnicity, and class. A Black male in the second-year class believed that extensive extracurricular activities were important ways to interact with his peers: "I think that education is one of the only times people are gomg to be together from diverse backgrounds. This is one of the only times you get to know people in a nonthreatening environment where you're not competing to move up the corporate ladder. You need that opportunity."317 A White woman in the first-year class used her involvement in the Workers' Rights Clinic to keep in touch with "ordinary folks in the comnuunity who probably needed a lawyer." She also was a member of the Lesbian, Gay, Bisexual, and Transgendered Caucus and the National Lawyers Guild, organizations that spoke to her personal identity and ideology. $^{318}$

When students became involved in extracurricular activities, they generally reported that women were at least as involved as men and sometimes more involved, ${ }^{319}$ with the level of participation depending on the organization. In general, women were perceived as giving more of their tine and energy to the organizations they joined than men did. Their engageinent soinetimes seemed to reflect a deep personal commitment as well as strong time management skills. The Berkeley Women's Law Journal $(B W L J)$ was dominated by women, a characteristic that some students singled out as appealing. ${ }^{320}$ In addition to $B W L J$, students stated that woinen were inore involved than inen in organizations dedicated to racial and social justice, including the Coalition for a Diverse Faculty and

\footnotetext{
316. See Interview with Student No. 131, supra note 212.

317. Interview with Student No. 62, supra note 198.

318. Interview with Student No. 42, supra note 189.

319. See, e.g., Interview with Student No. 8, supranote 190; Interview with Student No. 26, supra note 205 (women more involved than men); Interview with Student No. 28, supra note 253; Interview with Student No. 33, supra note 178; Interview with Student No. 37, supra note 192; Interview with Student No. 39, supra note 205; Interview with Student No. 41, supra note 236; Interview with Student No. 42, supra note 189; Interview with Student No. 43, supra note 185; Interview with Student No. 46, supra note 212; Interview with Student No. 51, supra note 179; Interview with Student No. 55, supra note 294; Interview with Student No. 56, supra note 184; Interview with Student No. 58, supra note 205 (women more involved than men); Interview with Student No. 59, supra note 189; Interview with Student No. 60, supra note 189; Interview with Student No. 61, supra note 205; Interview with Student No. 63, supra note 258 (women more involved than men); Interview with Student No. 69, supra note 186; Interview with Student No. 77, supra note 218; Interview with Student No. 96, supra note 222; Interview with Student No. 120, supra note 182.

320. See Interview with Student No. 38, supra note 265; Interview with Student No. 65, supra note 199 (liked nonhierarchical structure); Interview with Student No. 71, supra note 180; Interview with Student No. 75, supra note 205; Interview with Student No. 90, supra note 188; Interview with Student No. 115, supra note 180 (chose not to work for a male-dominated journal).
} 
Student Body, ${ }^{321}$ Law Students of African Descent, ${ }^{322}$ La Raza Law Students Association, La Raza Law Journal, ${ }^{323}$ Asian Pacific American Law Students Association, ${ }^{324}$ and public interest activities. ${ }^{325}$ Only a few organizations were reported to be dominated by men. ${ }^{326}$ According to one student, even in the conservative Federalist Society, men made up most of the membership, but women took charge. ${ }^{327}$ Indeed, the representation of women in student organizations was so strong that two students mentioned the dearth of males on the editorial board of the California Law Review $(C L R)$. According to a White woman in the second-year class, "CLR was criticized last year for only having one White heterosexual male ... on the $C L R$ ed[itorial] board. I think at that point, [a member] came out of the heterosexual closet and said, 'No, I'm here and I'm straight.' It's been basically diverse, which has been really great." 328

\section{b. Racial and Ethnic Parity: A Tale of Two Journals}

Students had mixed views about whether there was racial and ethnic parity in the organizations in which they participated. Two student organizations, California Law Review (CLR) and the Berkeley Women's Law Journal ( $B W L J)$, addressed the issue explicitly, which provoked considerable controversy. $C L R$ adopted a program to diversify its membership out of a concern that people of color were underrepresented among its prestigious ranks. One White woman spoke positively about the diversification effort as a way to influence legal scholarship and enhance the representation of people of color in prestigious law firms:

[O]ur group this year is especially proud of the fact that we have an especially diverse group and that we think that positively impacts the articles that we pick, how we put things together. Not only that but ... partners at the law firms are embarrassingly low on minorities. And their arguments are "There are a smaller number of minorities in the law school to begin with and the top students from that. ..."And Law Review is just one of those small things, so it's

321. See Interview with Student No. 62, supra note 198 (Black male).

322. See Interview with Student No. 50, supra note 205 (Black male).

323. See Interview with Student No. 63, supra note 258 (Latino male); Interview with Student No. 80, supra note 189 (Latino male).

324. See Interview with Student No. 84, supra note 205 (Asian-American female).

325. See Interview with Student No. 73, supra note 254 ("I think public interest in general draws more women"); Interview with Student No. 134, supra note 239 (Homeless Outreach Program).

326. See Interview with Student No. 35, supra note 254 (Boalt Democrats); Interview with Student No. 70, supra note 254 (Ecology Law Quarterly); Interview with Student No. 115, supra note 180 (Berkeley Journal of Employment and Labor Law).

327. See Interview with Student No. 47, supra note 180.

328. Interview with Student No. 55, supra note 294; see also Interview with Student No. 133, supra note 182 (mentioning that $C L R$ 's top three positions were held by women). 
just kind of like, "Hey, adding to the pool, giving them less excuse." 329

Even students agreeing that $C L R$ was more representative, however, noted that the diversification effort was only partially successful in dispelling the journal's image as exclusionary:

Generally, it has been a problem, more so now [due to the drop in Black and Latino law students]. . . . It's hard because not everyone is welcome. You have to get on, so in a sense it is exclusive and keeps people out. I think probably in the past it keeps non-White males out. Over time, it has become less that way. I certainly don't feel as a woman I was kept out. ${ }^{330}$

A Black student's comments about his experience on CLR raised doubts that representation alone led to a meaningful exchange of ideas. This student described a competitive, individualistic atmosphere in which he chose not to share much of himself with his peers:

$C L R$ was a very interesting organization that had a circular argument. What I mean by that is: "I am somebody because I am on $C L R$. Because I am on $C L R$, I am somebody. I am smart because I am on CLR. Because I'm on CLR, I am smart." I sort of saw $C L R$ as a job. I would go there, do my job, and get the hell out, while other people were more interested in making the place more accessible. I'm like 'I'm not trying to hang out with you, punk. Who are you kidding?" Again, for me, it was very fly by night. It was not a cohesive thing. ${ }^{331}$

The diversification effort generated some strong critics. An Asian-American male member of $C L R$ questioned the justifications for tinkering with its racial composition and traditional selection process: "I don't see why any woman or minority would feel constrained from trying out for it. It's totally colorblind and then you have this personal statement [that is considered along with a writing sample and cite-checking exercise in deciding who becomes a niember]. ${ }^{\text {"332 }}$ Indeed, the diversification policy was eliminated one year after its adoption, prompting one Black male member to quit due to a "racial dynamic" underlying the debate over whether to end the policy. ${ }^{333}$

Unlike CLR, the Berkeley Women's Law Journal (BWLJ) has not excluded individuals from nembership based on a competition. That kind of selection process would be inconsistent with its nonhierarchical structure

329. Interview with Student No. 55, supra note 294; see also Interview with Student No. 26, supra note 205 (explaining the benefits primarily in terms of the representativeness of the editorial board without connecting the shift to larger social objectives).

330. Interview with Student No. 26, supra note 205.

331. Interview with Student No. 23, supra note 187.

332. Interview with Student No. 133, supra note 182.

333. See Interview with Student No. 23, supra note 187. 
and community orientation. Part of BWLJ's mission is to address the concerns of women of color, but it too has found it difficult to attract minority students to its ranks. Even when wonen of color were present, retention in the face of conflicting priorities became a difficult task. ${ }^{334}$ One White woman in the first-year class noted that part of the "history of the journal" was that it "lost a lot of women of color." 335 In particular, "there was a group of women of color that were really in support of [an article], and it ended up getting voted down, and they were really upset about that. I think they were upset about the process, so... [s]ome of them left the journal." ${ }^{336}$ While most students noted that the lack of wonien of color in1peded $B W L J$ 's ability to fulfill its institutional goals, one White female student thought that their absence also reduced the social benefits of participating:

$B W L J$ doesn't at all have diversity among race or gender which, I think, is a drawback. From the beginning, I didn't look at it as an organization that would be personally fulfilling or that it would meet that need for me. It was a place that I knew I wanted skills, and I could go there to get them. Specifically, because it's not race or gender mixed, I'm not comfortable with it as a social base. ${ }^{337}$

Sonie students went on to note that the schisn1 at $B W L J$ reflected a larger controversy surrounding the feminist movenient. As one put it:

It was raised by women of color that feminist organizations aren't addressing their problenis at all. I think that's still something that's very much alive in women, that may feel like joining in, is that feminist organizations in general aren't very aware about issues about race. Our journal is very proactive about that, and yet it still doesn't seem to help. ${ }^{338}$

Several students also believed that women of color felt torn between commitments to women's organizations on the one hand and to racial and ethnic organizations on the other. Very often, they chose the latter. As one wontan explained:

The Women's Law Journal has always had a problem attracting wonien of color, and there has been this "Oh, women of color need to choose. As an African Anierican, are you going to choose

334. See, e.g., Interview with Student No. 34, supra note 215 (describing a conflict over an article which caused a group of women of color to leave the journal); Interview with Student No. 75, supra note 205 (noting controversy and tension between two Whites, who were co-editors-in-chief, and women of color, who were members of the journal).

335. Interview with Student No. 34, supra note 215.

336. Id.

337. Interview with Student No. 90, supra note 188.

338. Interview with Student No. 34, supra note 215; see also Interview with Student No. 71, supra note 180 (noting general perceptions of women's organizations as predominantly White). 
African American.Law and Policy Report or are you going to join the Women's Law Journal?" 339

According to some students, the predominantly White composition of $B W L J$ was self-perpetuating. One thought that she would be deterred from joining "if I was a student of color and I was going into a room and saw that most of the staff was White and the people in charge were White." 340 Another remarked:

There's a not-so-infrequent feeling of tokemization, not like you've been asked to be on the Journal so that they can have their person of color, but more that a little too often you feel like you have to speak for your entire race, which is a little odd. I think that certainly brought up some tensions. ${ }^{341}$

Interestingly, these two examples of problems with diversification reveal very different conceptions about why inclusion is important. Only one member of CLR mentioned that the policy might change the way articles were reviewed and improve the opportumities for minorities at large law firms. The others discussed the issue as one involving the representativeness of an organization traditionally seen as elitist and exclusionary. The policy's benefits were linked to a general sense of fairness, rather than to $C L R$ 's ability to publish high-quality legal scholarship. Indeed, soine were concerned that a focus on diversity might undermine the process of choosing members by injecting irrelevant considerations. At BWLJ, however, diversification was not understood as simply a "numbers game" but as a necessary consequence of a shared institutional mission. As a result, members focused on how the lack of diversity diminished $B W L J$, rather than on how diversification promoted a norm of racial equity.

\section{c. The Impact of Colorblind Admission on Racial and Ethnic Organizations}

In addition to addressing gender and racial parity within existing student organizations, a number of students discussed the impact of the new admissions policy on racial and ethnic organizations. Many predicted that without affirmative action, racial and ethmic orgamizations at the law school would wither and die. ${ }^{342}$ Yet, far from mourning the passing of these

339. Interview with Student No. 45, supra note I95. See also Interview with Student No. 38, supra note 265; Interview with Student No. 65, supra note 199.

340. Interview with Student No. 115, supra note I80.

341. Interview with Student No. 65, supra note 199.

342. See, e.g., Interview with Student No. 9, supra note 223; Interview with Student No. 28, supra note 253; Interview with Student No. 35, supra note 254; Interview with Student No. 49, supra note 212; Interview with Student No. 50, supra note 205; Interview with Student No. 56, supra note 184; Interview with Student No. 58, supra note 205; Interview with Student No. 62, supra note 198; Interview with Student No. 63, supra note 258; Interview with Student No. 66, supra note 181; Interview with Student No. 69, supra note 186; Interview with Student No. 70, supra note 254; Interview with Student No. 73, supra note 254; Interview with Student No. 74, supra note 225 ; 
organizations, a few students believed that these organizations had been part of the problem when Boalt had affirmative action:

My first year I got really upset and really mad at the way in which ... the students were recruited to the minority law journals. I thought that was really upsetting because a student of color would walk in the door and it would be, "This is where you're supposed to be hanging out." ... I didn't like that very much, but as soon as people started interacting with the rest of the community, that broke up really quickly. ${ }^{343}$

This student's discomfort with racially and ethnically identifiable organizations was not idiosyncratic. Other students noted that Whites sometimes resented student groups that recognized and reinforced racial differences. A Black male in the second-year class said that he had heard rumors that White students "were putting together this White association, they were going to have an open association that said, 'We are the White students, you can come in if you want, it's not restricted to White students." 344 The association was designed to highlight the ironies of having racial and ethnic organizations at Boalt that were technically open to everyone. This student found the irony lay elsewhere because by creating "minority cliques," "[t]he greatest groups that are trying to solve the problem and are doing the greatest good are also doing the greatest harm." ${ }^{345}$ A White woman in the first-year class dismissed fears that these organizations led to selfsegregation, calling Boalt less divided than other academic institutions. ${ }^{346}$

Consistent with the results reported by Antonio and the Diversity Project at Berkeley, students expressed mixed feelings about racial and ethnic organizations at Boalt. Law students appear to have been a bit more tolerant of these student groups than undergraduates, perhaps because they had grown accustomed to such organizations in college. In general, the organizations did not particularly bother inost students, but a few strongly believed them to be balkanizing and harmful. This research expands on the earlier work by allowing students to describe the role of other identity traits in their choice of organizational affiliations. For example, none criticized groups that focus on the needs of gays and lesbians, older students, or the disabled. In addition, only one student complained about having a women's organization. ${ }^{347}$ Divisions based on gender, sexual orientation,

\footnotetext{
Interview with Student No. 75, supra note 205; Interview with Student No. 80, supra note 189; Interview with Student No. 120, supra note 182; Interview with Student No. 133, supra note 182; Interview with Student No. 134, supra note 239.

343. Interview with Student No. 53, supra note 195 (White male).

344. Interview with Student No. 57, supra note 234.

345. Id.

346. See Interview with Student No. 103, supra note 225.

347. See Interview with Student No. 52, supra note 196 (opining that since there was a Women's Resource Center, there should be a Men's Resource Center in the spirit of equality).
} 
age, or disability simply did not trigger the same anxieties as separation along racial and ethnic lines. Part of the legacy of integration seems to be that any preference for same-race organizations, even voluntarily chosen ones, is suspect. Racial and ethnic student associations have paved the way for other groups to form around shared identities. Ironically, these other groups seem to enjoy widespread acceptance, while their color-conscious predecessors are still perceived as potentially antisocial.

\section{d. Student Organizations and the Partial Realization of Powell's Vision}

Powell's vision of a pedagogy of diversity turns heavily on students' interactions with their peers. Yet, the organizations that students managed and staffed did not always lead to the sharing of personal history and perspective. For those who believed that positions as members or officers were mainly "inerit badges" for a résumé, the key was to earn the badge by performing the necessary tasks. Participation was not a form of selfexpression or self-direction. Instead, involvement was purely instrumental, a way to improve the chances of landing the job of one's choice, and by no means integral to building a unique professional identity. The more prestigious and traditional the activity, the more likely that students would view it as a credential rather than a calling. When extracurricular commitments became valuable commodities to be earned for one's résumé, diversification efforts were likely to be criticized as a form of "reverse discrimination," with soine candidates gaining an unfair competitive advantage without substantially advancing the organization's imission. As a result, diversification was particularly controversial at $C L R$, where some members beheved that colorblindness was the only fair policy.

In contrast, activities that highlighted research on or service to disadvantaged communities treated identity concerns as integral to the theory and practice of law. For these organizations, diversity was essential to carrying out the institutional mission. $B W L J$ did not target a specific racial or ethnic group, but it did seek to serve the underrepresented. In doing so, members understood diversity to be a sine qua non of optimal functioning, and without it, at least one participant reported that she began to treat her journal work as just a way to build skills, rather than a way to forge friendships and a sense of herself as a person and a professional. At $B W L J$, then, diversity was not a distracting sideshow but instead was a core component of the organization's self-definition.

By bringing personal identity to the fore, racial and ethnic organizations further challenged a vision of extracurricular activities as inere credentials. Organizations like the African American Law and Policy Report and La Raza Law Journal could not survive without students who prioritized these racial and ethnic concerns. Predictably, Black and Latino students overwhelmingly staffed these journals as a way of affirming their 
commitment to giving voice to the underrepresented. When most students predicted that these journals would disappear without affirmative action, they also were indicating that White and Asian-American students typically do not feel able or willing to devote themselves to these identitybuilding efforts. Apparently, these organizations created a sense of "ownership" of some issues, one that converted outsiders into interlopers who were usurping an identity and inappropriately seeking a credential. ${ }^{348}$

\section{Friendships}

In addition to working together on extracurricular activities, students interact informally, chatting over coffee, going to a movie, or jogging together. Those friendly exchanges offer another opportunity for students to share their experiences and ideas. However, friendships are hampered by a competitive law school atmosphere and patterns of self-segregation.

\section{a. The Lonely Crowd}

When asked about their friendships, almost one in five students in the study rephed that they had no close friends at Boalt. ${ }^{349}$ One student attributed her decision to spend time with friends outside the law school this way: "I'm a law student in denial still." ${ }^{350}$ Even a student who had made a few close friends in his first year of law study commented on the lack of social cohesion at Boalt: "Get to law school and a lot of the people have already forged a life before they came here, and they stick to that life ...."351

Several students indicated that their close friendships had been forged before law school. Another student who had transferred to Boalt after his first year described his closest friends at the school as "nonexistent,"

348. See INSTITUTE FOR THE STUdY OF SOCIAL CHANGE, supra note 161, at 39 (noting that White undergraduates felt excluded from racial and ethnic organizations because they received the message that "they can never know what it means to be a minority precisely because they are White").

349. See Interview with Student No. 34, supra note 215 (White female); Interview with Student No. 35, supra note 254 (White male); Interview with Student No. 37, supra note 192 (White male); Interview with Student No. 42, supra note 189 (White female); Interview with Student No. 51, supra note 179 (Latina female); Interview with Student No. 57, supra note 234 (Black male); 1nterview with Student No. 61, supra note 205 (White male); Interview with Student No. 63, supra note 258 (Latino male); Interview with Student No. 73, supra note 254 (Asian-American female); Interview with Student No. 75, supra note 205 (White female). See also Interview with Student No. 23, stupra note 187 (gay male reports spending time with other gay men at the Law School, but expresses doubts that he has close friends at Boalt); Interview with Student No. 33, supra note 178 (White male) (friends but not close friends); Interview with Student No. 57, supra note 234 (Black male who said his "closest friends" weren't those at Boalt and that it "seems like a hostile place where people don't like each other."). Five students were excluded from the analysis because they provided insufficient or conflicting information about their friendships at Boalt. They were No. 6, No. 28, No. 52, No. 90, and No. 131 .

350. Interview with Student No. 75, supra note 205.

351. Interview with Student No. 6, supra note 205. 
saying "I haven't really made too many close friends here."352 Other students noticed that it was more difficult to make good friends at Boalt than it had been as an undergraduate. A Latino male was not sure why he had failed to make close friendships at Boalt as he had in college: "I just don't think I've made the qualitative relationships that I have made at some other stops. There's no one that I would really call or have the depth of personal relationship that I've found in other instances in my life." ${ }^{\text {"353 }}$ Some students regretted that they had not been able to develop close friendships with classmates, yet held hope for improvement in the future. ${ }^{354}$

\section{b. Patterns of Friendship and Self-Segregation}

When students did form friendships with classmates, only a few described their friends as racially homogeneous and all of the same $\operatorname{sex}^{355} \mathrm{~A}$ larger number of students reported having racially homogeneous friendships that included both men and women. ${ }^{356}$ The overwhelming number of students with racially homogeneous friendships were White, although two Asian-American students reported having all Asian-American friends. ${ }^{357}$ White students often blamed the racial homogeneity of their friends on the lack of diversity in the first-year class. ${ }^{358}$ Of those students with a racially diverse groups of friends, slightly more than half also reported that their friendship group included both men and women. ${ }^{359}$ A little less than half

352. Interview with Student No. 37, supra note 192.

353. Interview with Student No. 63, supra note 258; see also Interview with Student No. 57, supra note 234 (describing closest friends as "people that I've known for years," not people at Boalt where "I don't know anyone"); Interview with Student No. 61, supra note 205 (describing his friendships as ones that "already existed before I came to Boalt"); Interview with Student No. 75, supra note 205 (social life is spent with "nonlaw students" because she already had an established group of friends in the area).

354. See Interview with Student No. 42, supra note 189 (lamenting a lack of friendships developed during the first year but hoping for more by graduation).

355. See, e.g., Interview with Student No. 47, supra note 180 (White male); Interview with Student No. 53, supra note 195 (White male); Interview with Student No. 70, supra note 254 (White female); Interview with Student No. 84, supra note 205 (Asian-American female).

356. See, e.g., Interview with Student No. 9, supra note 223 (White male); Interview with Student No. 26, supra note 205 (White female) (all of her friends were White males); Interview with Student No. 39, supra note 205 (White male); Interview with Student No. 49, supra note 212 (White female); Interview with Student No. 55, supra note 294 (White female); Interview with Student No. 56, supra note 184 (White male) (all White female friends); Interview with Student No. 69, supra note 186 (White female); Interview with Student No. 71, supra note 180 (White female); 1nterview with Student No. 74, supra note 225 (Asian immigrant male); Interview with Student No. 114, supra note 180 (White male).

357. Of those with racially homogenous friendships, 12 were White (No. 9, No. 26, No. 39, No. 47 , No. 49 , No. 53 , No. 55 , No. 56 , No. 69 , No. 70 , No. 71 , and No. 114 ) and two were Asian American (No. 74 and No. 84).

358. The following first-year students mentioned how the lack of diversity constrained their choice of friends: No. 41, No. 58, No. 63, No. 71, No. 80, and No. 120.

359. See Interview with Student No. 8, supra note 190 (White female); Interview with Student No. 23, supra note 187 (Black male); Interview with Student No. 31, supra note 225 (Asian-American female); Interview with Student No. 33, supra note 178 (White male); Interview with Student No. 38, 
said that their friendships, though including classmates from other racial and ethnic backgrounds, included only members of the same sex ${ }^{360} \mathrm{~A}$ number of students described their friendships as racially diverse because they included both Whites and Asian Americans, ${ }^{361}$ but again not too much can be read into this pattern, given the racial composition of the law school.

Although about two-thirds of the students who had developed friendships said that their close friends were racially diverse, all but a handful of the participants reported patterns of self-segregation at Boalt. ${ }^{362}$ Most of the discussion focused on race and ethnicity, but some participants did mention other characteristics that divided students, including ideology, ${ }^{363}$ age, ${ }^{364}$ sexual orientation ${ }^{365}$ gender ${ }^{366}$ disability ${ }^{367}$ and immigrant status. ${ }^{368}$ Those who mentioned these traits typically identified with them in some way. So, for example, older students mentioned age; gay and lesbian students,

supra note 265 (White female); Interview with Student No. 43, supra note 185 (Asian-American male); Interview with Student No. 50, supra note 205 (Black male); Interview with Student No. 59, supra note 189 (White male); Interview with Student No. 62, supra note 198 (Black male); Intervicw with Student No. 66, supra note 181 (White female); Interview with Student No. 68, supra note 205 (White male); Interview with Student No. 77, supra note 218 (White female); Interview with Student No. 79, supra note 212 (Asian-American female); Interview with Student No. 80, supra note 189 (Latino male); Interview with Student No. 103, supra note 225 (White female); Interview with Student No. 115, supra note 180 (White female); Interview with Student No. 133, supra note 182 (Asian-American male); Interview with Student No. 134, supra note 239 (White female).

360. See Interview with Student No. 15, supra note 235 (Asian-American female); Interview with Student No. 30, supra note 183 (Latino male); Interview with Student No. 36, supra note 268 (Whitc male); Interview with Student No. 41, supra note 236 (Latina female); Interview with Student No. 45, supra note 195 (White female); Interview with Student No. 46, supra note 212 (White female); Interview with Student No. 58, supra note 205 (Asian-American female); Interview with Student No. 60, supra note 189 (White fcmale); Interview with Student No. 65, supra note 199 (Asian-American female); Interview with Student No. 96, supra note 222 (White female); Interview with Student No. 101 , supra note 252 (White male); Interview with Student No. 120, supra note 182 (Whitc male).

361. See Interview with Student No. 31, supra note 225; Interview with Student No. 36, supra note 268; Interview with Student No. 46, supra note 212; Interview with Student No. 60, supra note 189; Interview with Student No. 65, supra note 199; Interview with Student No. 66, supra note 181; Interview with Student No. 79, supra note 212.

362. Only three students reported that self-segregation was not a problem at Boalt. See Interview with Student No. 50, supra note 205 (Black male); Interview with Student No. 103, supra note 225 (White female); Interview with Student No. 120, supra note 182 (White male).

363. See Interview with Student No. 36, supra note 268 (White malc); Interview with Student No. 55, supra note 294 (White female); Interview with Student No. 65, supra notc 199 (Asian-American male); Interview with Student No. 75, supra note 205 (White female); Interview with Student No. 115, supra note 180 (White female).

364. See Interview with Student No. 75, supra note 205 (31-ycar-old); Intervicw with Student No. 80, supra note 189 (26-year-old); Interview with Student No. 115, supra note 180 (26-year-old).

365. See Interview with Student No. 35, supra note 254 (gay male); Intcrview with Student No. 60, supra note 189 (lesbian); Intervicw with Student No. 66, supra note 181 (gay male).

366. See Interview with Student No. 60, supra note 189 (White female); Interview with Student No. 90, supra note 188 (White female).

367. See Interview with Student No. 55, supra note 294 (disablcd White female).

368. See Interview with Student No. 74, supra note 225 (Asian male immigrant). 
sexual orientation; women students, gender; a hearing impaired student, disability; and a foreign-born student, immigrant status.

When students mentioned gender segregation in friendships, they sometimes noted that they engaged in different activities with men and women. One White woman im the first-year class described shopping and painting her nails with friends, ${ }^{369}$ while several men noted that they liked to play sports, go to bars, and "be crude" with other men. ${ }^{370}$ Another male student noted that he was more comfortable having men rather than women as friends because he was married and did not want to go looking for trouble. ${ }^{371}$ Interestingly, these students did not necessarily see gender segregation as harmful, nor did they attribute it to the existence of women's organizations at the law school. Instead, the students associated same-sex friendships with shared interests and personal comfort without questioning very closely an underlying process of sexualized socialization.

Students offered varying explanations for why racial and ethnic selfsegregation occurred. One White woman in the upper division blamed racial and ethnic organizations when asked why students did not mix socially:

[The] Welcome Day that I came to a few years back at Berkeley pissed me off because it was almost totally divided along racial lines. We had a speaker from La Raza, a speaker from LSAD [Law Students of African Descent], these different things, which was great. I was like, "All these different groups," and then we split up for lunch, and the Black student group took Black students ... . the White students were sitting there and the guy from the student government came on and said, "O.K., l'll take anyone left to lunch." I remember thinking "Wait a minute, I was talking to that guy. I wanted to go to lunch with that guy, and he went off with the Black student union." . . I don't want to be limited to eating lunch with the people at student government just because La Raza took everyone else. Right then, it started, I think, on Welcome Day, when you split up people to eat based on their race. So from then on, that's where you go. You feel more comfortable talking to a woman professor, Black people feel comfortable.... I understand the dynamics, but they are just entrenched. The spotlight is put on them here. ${ }^{372}$

A Black male student in the second-year class offered quite a different diagnosis of the roots of self-segregation. In his view, Whites were the only racial group at Boalt with the ability to keep to themselves:

369. See Interview with Student No. 46, supra note 212.

370. Interview with Student No. 133, supra note 182 (Asian-American male). See also Interview with Student No. 61, supra note 205 (White male) (extreme sports); Interview with Student No. 120, supra note 182 (White male) ("opposite sex for coffee, same sex if you go to a bar");

371. See Interview with Student No. 52, supra note 196 (White male).

372. Interview with Student No. 134, supra note 239. 
I think that most students of color have a racially diverse group of friends just because there are more Whites. Whites have the ability to just kind of have White friends, but I think students of color, for the most part, have friends of all different races because a lot of times students of color work together on a lot of issues. La Raza, Law Students of African Descent, APALSA [Asian Pacific American Law Students Association] for Asian students, work together. I think that a lot of us are in classrooms with White students, and I think that a lot of us become friends in that way. It's easier for White students not to have friends that are students of color. ${ }^{373}$

Not surprisingly, these differences in viewpoint correlated with distinct ideas about the impact of the new colorblind admissions policy on friendships. Three students, all Asian Americans, believed that the change would force the small number of students of color to cross racial boundaries to find friends. An Asian-American man in the upper division explained: "[T]f there's actually only one or two minorities in a class, it's a lot easier to become friends with White people, I guess, than if there's thirty of you." ${ }^{374}$ An Asian immigrant male echoed this view, lamenting that failure to make friends across racial lines cuts against the "ideal that Boalt was supposedly wanting to achieve":

I suppose if you are going to be the last African American, you will just have to, unless you want to be isolated, you will just have to start making friends with the other races. At this point, they are really segregated.... Walking down the hall, you see a group of African Americans talking with each other. You see a group of White people. That kind of stuff. But I know for a fact, if you are going to be the only person of your race, you will just have to reach out or be isolated. ${ }^{375}$

By contrast, a Black male in the second-year class thought that the new policy would tokenize people of color and damage the authenticity of interracial friendships:

I think that the students of color that are here will make some White friends, but maybe you might be questioning why they want to be friends with you. Is it because they want to appease the liberal

373. Interview with Student No. 62, supra note 198.

374. Interview with Student No. 43, supra note 185 (describing the differences between his high school experience, as the only Asian American in the school, and his experience in higher education where there were substantial numbers of Asian-American students); see also Interview with Student No. 131, supra note 212 (Asian-American female in first-year class) (describing her expectation that her friends would be exclusively Asian American and her ultimate need to seek out racially diverse friends, which led her to conclude that the inability to self-segregate was a benefit of the new admissions policy).

375. Interview with Student No. 74, supra note 225. Interestingly, this student's friends were all Asian immigrants. See id. 
ideology or is it because they genuinely want you as a friend? I guess what I'm saying is that some minority students might feel like tokens because they're not really sure if people are genuine about their friendship as opposed to being on the right side of an issue, for instance. ${ }^{376}$

A White woman in the first-year class expressed concern about the impact of tokenization on racial discourse at the law school and the educational experiences of the small number of students of color:

[O]ne thing that facilitates mixed groups of people is everybody having enough of a critical mass of all the groups .... I feel like if there are very few people of color, that they will feel the need to stick together more, spend more time with each other, and to be more hesitant to go into other groups because even if people are very well intentioned, I think you could kind of end up treating people like "Oh, you're Black, what's your perspective?"377

A few students addressed the mipact of the new policy on relationships between Whites and Asian Americans. A White male student expressed dismay that the change in admissions policy had led to clusters of Asian-American students on the one hand and White students on the other:

It's just not the same place. Every place that I used to count on being like a diverse area ... it's just not as diverse.... The most noticeable cluster is just [groups of] White people. Now there's these really strong clusters of Asians. You see large groups of exclusively Asians that sit together, talk together, hang together. I never thought of Latimos or African Americans traveling in packs in the last few years, and I was always very proud of that. ${ }^{378}$

The issue of self-segregation apparently was a topic of debate among Asian-American students themselves. A racially mixed male of Asian-American descent in his first year of law study tried to explain the tendency of Koreans to "clique" together, saying, "I don't think it's because they want to exclude non-Koreans, for example, but it's just because that's who they feel more comfortable with.... I don't think that's necessarily bad."379 In a later interview, however, this person's study partner, an Asian-American woman, went out of her way to disagree, referring to his comments in saying, "he told me that you guys asked that question, and he pointed out that some of the Asian people tend to 'chique' together. But I'm not really sure if I agree or not." ${ }^{2380} \mathrm{~A}$ White woman in the

\footnotetext{
376. Interview with Student No. 62, supra note 198.

377. Interview with Student No. 103, supra note 225.

378. Interview with Student No. 53, supra note 195; see also Interview No. 114, supra note 180 (describing the "balkanization" of Asian Americans and Whites)

379. Interview with Student No. 6, supra note 205.

380. Interview with Student No. 79, supra note 212.
} 
upper division also observed that "I have a lot of friends who are Asian, and some of them have really different feelings about whether they feel more set apart or not." 381

\section{c. Friendships, Balkanization, and the Exchange of Ideas}

Friendships at Boalt had a mixed record of success in promoting a diverse exchange of ideas. A significant minority of students reported having no close friendships at the law school. Some arrived with established friendships that sustained them, while others struggled to overcome the isolation of a competitive educational climate. In either case, these students did not capitalize on the diversity of their peers through informal exchange.

As in Antonio's survey of friendships at a diverse California campus, ${ }^{382}$ Boalt students said that they themselves had friends of different races but that the student body segregated itself along racial and ethnic lines. Although students also formed friendships on other bases such as gender, age, ideology, sexual orientation, and disability, none of these divisions elicited the same anxiety or obloquy as race and ethnicity. As in Antomio's research, students sometimes blamed racial and ethnic organizations that recruited members to their ranks even before classes had begun. Apparently, many students at Boalt did gain the benefits of interracial friendships that Powell envisioned, but some of them were frustrated because they believed that even more interchange was possible and desirable.

What this study adds is some sense of the impact of colorblind admissions policies on friendship patterns. By creating two primary racial constituencies at the law school, Whites and Asian Americans, the new admissions procedure has not put an end to balkanization but has instead shifted the color lime. Asian-American students disagree among themselves about whether there is self-segregation and, if so, whether it is necessarily wrong. It remains unclear whether the potential divide between Whites and Asian Americans will evoke the same anxieties that perceived selfsegregation of Blacks and Latinos did.

Nor has the policy assured a free exchange of ideas for the small number of Black and Latino students who enroll at Boalt. Although these students are now less able to rely on same-race friendships than before, they can continue to "segregate" their authentic selves from friendships that feel forced or contrived. That is, they may balk at being commodified into a badge of their peers' liberal bona fides or a spokesperson for the absent and underrepresented. To protect themselves from tokenization, these students could wind up using the strategies that Kanter identified: they will become superachievers or low-profile loners. As superachievers, they

381. Interview with Student No. 66, supra note 181.

382. See Antonio, supra note 114. 
will focus on the impersonal task at hand. As loners, they will carefully ration their social contact. In either case, they will reveal relatively little of their inner lives.

\section{Views About Affirmative Action in Admissions}

Most of the students in this study favored some form of affirmative action. A little over two-thirds favored the use of race alone or in combination with socioeconomic status in making admissions decisions. Slightly less than one-third thought race should not be weighed in the admissions process; of this group, there was an even split between those who would use economic disadvantage as a substitute and those who would not. ${ }^{383}$ Whatever conclusion they reached, most students appreciated the complexity of the issues and the normative uncertainty that resulted.

\section{a. The Pros and Cons of Affirmative Action}

Those who favored considering race in admissions differed in their reasons. Some emphasized the importance of diversity to the law school's educational mission. As a Latino male in the first-year class put it:

[I]t's important to remember that this is an institution that is training people who are going to be the leaders .... [P]eople of color are here to stay ... and there's going to be a point where White students are going to deal with people of color. So it's to their advantage as well as our advantage to have more students of color. In addition ... the students of color here are going to be ... the leaders of their commumities in several different ways, as attorneys, as administrators, as policy makers, as professors.... It's important that, especially in law school, that is the training ground for leaders, that it be diverse in both ways, in education of the status quo and of the education of students of color who can then go out and be leaders of their community. ${ }^{384}$

A White woman in the upper division echoed these views, saying that changes in the law governing admissions meant Boalt could no longer "take seriously [its] role ... as a public institution":

383. The following interviewees favored a colorblind system with little or no weight given to socioeconomic disadvantage: No. 6; No. 9; No. 37; No. 58; No. 74; No. 77; No. 101; No. 120; No. 133. The following interviewees preferred a system that weighed race but gave little or no weight to socioeconomic disadvantage: No. 15 ; No. 23 ; No. 26 ; No. 33 ; No. 34 ; No. 36 ; No. 38 ; No. 41 ; No. 45 ; No. 50 ; No. 59 ; No. 61 ; No. 63 ; No. 65 ; No. 66 ; No. 68 ; No. 73 ; No. 79 ; No. 80 ; No. 84 ; No. 90 ; No. 103; No. 114; No. 131. The following interviewees favored a system that considered socioeconomic disadvantage but gave little or no weight to race: No. 30 ; No. 31 ; No. 35 ; No. 39 ; No. 43 ; No. 46; No. 47 ; No. 51 ; No. 52. The following interviewees wanted both race and socioeconomic disadvantage to be considered: No. 8 ; No. 28 ; No. 49 ; No. 53 ; No. 55 ; No. 56 ; No. 58 ; No. 60 ; No. 62 ; No. 69 ; No. 70 ; No. 71 ; No. 75; No. 96; No. 115; No. 134. One student, No. 57 , was uncertain about the weight that he would give to race and socioeconomic status in the admissions process and did not state a position. See Interview with Student No. 57, supra note 234.

384. Interview with Student No. 80, supra note 189. 
I think that the fact that the tuition is so much lower here than at private school should not just be a benefit to a rich person who has a choice between either one.... [The] benefit of lower tuition is coming from the state, and the state has an obligation to educate a broad range of people who will do a broad range of things. If we're mostly educating people to go into corporate law, I just don't think that should be our only motivation. ${ }^{385}$

Another student expressed the concern that his class had "missed something as first years, being in a class where it's almost entirely White and upper class and that's the only perspective we're getting. ${ }^{.1386}$ This student found it "shocking, even depressing" and expressed his feeling that "the school is really losing something. ... That we should be so apathetic as to sit in class where we're discussing race and not even talking about race. It's just appalling [that racial issues are elided and avoided]." ${ }^{387}$

While some students supported considering race in admissions based on Boalt's role as a public institution or on the nature of the educational climate, others saw affirmative action as a less-than-ideal but necessary response to the ongoing reality of racial discrimination and segregation in the United States:

I think that there is still an extent to which Whites are privileged and that there are a whole set of reasons as to why Whites are doing better on these exams [the Law School Admissions Test]. There's still residential segregation. There's still educational segregation. ... I don't expect [Boalt] to fix all of that, but I do expect them to take that into consideration and say that we do have an obligation to account for those things, and that though it's an imperfect system, affirmative action is a way to do that. ${ }^{388}$

At least one student who supported affirmative action on this ground overcame her own sense of having been displaced by the program as an undergraduate:

I don't think affirmative action is perfect in the way it works, but it's the most immediate thing we can do right now. I think the best thing to do is overhaul the school system and give everyone an equal educational opportunity from grade one. ... I think about it a lot because I've been in situations like when I went to [an elite private school in the East]. It's a really competitive school to get in, and I got on the waiting list to begin with there, and I had a 4.0 and

385. Interview with Student No. 66, supra note 181.

386. Interview with Student No. 90, supra note 188.

387. Id.

388. Interview with Student No. 45, supra note 195 (White female in third-year class); see also Interview with Student No. 68, supra note 205 (White male in upper division) (calling affirmative action "unfortunate but necessary" because "discrimination is a fact of life and it hasn't gone away"); Interview with Student No. 79, supra note 212 (Asian-American female in the first-year class) ("As much as I hate to admit it, I think we need to have affirmative action right now .....'). 
whatever. ... My advisor called the school and said "Why didn't she get in?".... They basically said because I was White and female, there had been too many female applicants .... Those were the main reasons, which kind of bugged me at the time, but I ended up getting in .... In that sense, I feel like it has affected me. Also when I applied to law school, I applied to Yale and Stanford and didn't get in there.... I know someone who got into Stanford that I went to school with, who's Black, that I had been in classes with ... and he wasn't on the ball very much.... But then I think "I'm at Boalt. I'm going to do fine." It's not like it's ruining my opportunity to do anything. I feel like it's a good trade-off because... I've learned a lot more about desegregation and how long it's taken. It was still going on im the seventies and the eighties and things like that, which I didn't know. I wasn't really aware of that. I thought that it happened in ' 54 , that it happened a long time ago. I thought of it as history .... ${ }^{389}$

All students who favored a colorblind process were White or Asian American. They emphasized the dangers of reverse discrimination and the wrongful privileging of middle-class persons of color who had not been seriously disadvantaged:

People are always saying that minorities are disadvantaged from the beginning because they can't get in and they can't compete under the colorblind admissions thing. I don't know what to say. Maybe. If you don't get a good score on the LSAT, why should you get im? I just don't understand. ${ }^{390}$

This student went on to say that "[y]ou get Black people who have never been disadvantaged, really" but who nevertheless benefit from affirmative action. ${ }^{391}$ Given that, another student questioned whether privileged students of color actually brought a different perspective to the law school:

[T]o me, an African-American student that has grown up in Bel Air really might not have that different of a perspective on the law as another European-American citizen. I think that's why when you don't use an arbitrary category like race, and instead emphasize essays, personal experience, culture with the second language, then you'll still get a racially diverse group, but their experiences are diverse, too, not just this superficial category of race. ${ }^{392}$

Another student who rejected race-conscious admissions and favored reliance on LSAT scores and grade-point averages questioned whether racial diversity is necessary to foster a wide variety of viewpoints:

389. Interview with Student No. 34, supra note 215 (White woman in the first-year class).

390. Interview with Student No. 133, supra note 182 (Asian-American male in the third-year class).

391. Id.

392. Interview with Student No. 120 , supra note 182 (White male in the first-year class). 
I think to say that in order to get a learning environment where all points of view will be represented in terms of classroom discussion, to say that you need to have certain types of people to say those views, I think is very stupid. I think the learning environment in terms of discussion is going to be the same because people come here with different ideals. ${ }^{393}$

In addition to these doubts about whether affirmative action promoted fairness or diversity of viewpoint, one student voiced concern that the subsidy to students of color retarded their incentives to achieve their full academic potential:

[I]f you have a quota system, basically Asians compete with Asians, Whites compete with Whites, African Americans compete with African Americans. And, if the overall group has a lower caliber or has a higher caliber, then it is only going to give incentives for more differences.... They would have incentives not to work that hard. Then, as a result, the group gets lower and then you need more adjustments, more affirmative actions. And that's not going to correct 200 years of injustice . . . minorities have faced in the United States. I think you have to give incentives for internal sort of improvement instead of just giving things to those people. ${ }^{394}$

Students who favored weighing socioeconomic status in the admissions process often thought it was at least as important as race in measuring disadvantage. Among those who favored exclusive reliance on socioeconomic criteria, six were White, two were Latino, and two were Asian American. ${ }^{395}$ Notably, these were the racial groups most likely to benefit from a special program of admissions based on this type of disadvantage, according to a Boalt Hall report. ${ }^{396}$ Of those who supported consideration of both race and socioeconomic status, thirteen were White, one was Asian American, and one was Black. ${ }^{397}$ A number of the students who supported consideration of socioeconomic criteria also expressed ambivalence about affirmative action and at times wavered about the relevance of race. One student noted that despite the clear importance of class, it had been overshadowed by race because "it's easy to pin down your

393. Interview with Student No. 101, supra note 252 (White male in the first-year class) (noting also that "Boalt is not the only law school in the country" and that the LSAT and grade-point average standards do not discriminate against people).

394. Interview with Student No. 74, supra note 225 (Asian-American male in the upper division).

395. The following White students expressed this view: No. 35, No. 37 , No. 39 , No. 46 , No. 47 , and No. 52. The Latino students who adopted this position were No. 30 and No. 51. The Asian-Ameriean students were No. 31 and No. 43.

396. See Report on Socioeconomic Admissions, supra note 17, at 3-4.

397. The White students who endorsed this position were No. 8 , No. 28 , No. 49 , No. 53 , No. 55 , No. 60 , No. 69 , No. 70 , No. 71 , No. 75 , No. 96 , No. 115 , and No. 134 . The Asian-American student was No. 58, and the Black student was No. 62. 
race. I think it's a little harder to pin down your socioeconomic class ...."398 She went on to say that as a matter of policy, she preferred weighing economic criteria to racial ones:

[I] don't think there's as much difference between me and a Black student that grew up next door to me than there is between me and a White woman that grew up in the inner city. I think that there's more difference in the second case, even though we're both White women. I think it's more determinative of kinds of obstacles that you had to overcome growing up and doing things like getting your education. If you had to fight tooth and nail to get your education, you obviously really wanted it.... Obviously there was some other inotivation there, and I think that those are the kind of people that I would like to surround myself with. ${ }^{399}$

Another White woman in the upper division who had worked her way through college expressed a similar set of concerns:

I like the emphasis on economic disadvantage.... It's a little different when you see, like my ex-boyfriend caine from a very wealthy family. He was Black, went to this awesome school, had an education way better than mine, and I would think "Is affirmative action going to help him? Do we need it to help hin?" No. He needs help in another way. He needs to have people stop thinking of him because of his skin color.... I like the focus on, did you have a shitty school? Did you never have an A.P. [advanced placement] class? Did you never have a prep course for your SAT [Scholastic Aptitude Test]? I like the focus on that. ${ }^{400}$

\section{b. The Uncertain Meaning of Merit}

Students also expressed quite distinctive views about how to measure merit. ${ }^{401}$ Most students believed that undergraduate grade-point averages provided a good indication of academic promise for law study, but a number questioned the significance of the LSAT. Most who raised these doubts said they would keep the LSAT but reduce its weight in the admissions process. ${ }^{402}$ Although some students emphasized problems of fairness such

398. Interview with Student No. 60, supra note 189.

399. Id.

400. Interview with Student No. 134, supra note 239

401. One student suggested using a lottery to choose among applicants who met a minimum standard. See Interview with Student No. 42, supra note 189.

402. See, e.g., Interview with Student No. 15, supra note 235 (Asian-American female); Interview with Student No. 45, supra note 195 (White female); Interview with Student No. 51, supra note 179 (Latina female); Interview with Student No. 53, supra note 195 (White male); Interview with Student No. 55, supra note 294 (White female); Interview with Student No. 59, supra note 189 (White male); Interview with Student No. 65, supra note 199 (Asian-American male); Interview with Student No. 66, supra note 181 (White female); Interview with Student No. 69, supra note 186 (White female); Interview with Student No. 70, supra note 254 (White female); Interview with Student No. 71, supra note 180 (White female); Interview with Student No. 115, supra note 180 (White female); Interview 
as differential access to LSAT preparatory courses, ${ }^{403}$ others found it to be unfair in more fundamental ways. A White woman in the third-year class described her desire to make the LSAT less of a factor as stemming from the test's "cultural bias," "racial bias," and "gender bias." 404

On the other hand, the LSAT also had strong defenders. One White male student insisted that many of the skills that had been tested were quite relevant to his first-year law school experience:

I've noticed I used the same skills I did on the LSAT in my classes all the time. A perfect example is Property class.... We had the rules for grants of ownership and the rule for perpetuities, and it reminded me of a huge logic game that we had to perform. I also notice that the arguments section on the LSAT you had to compare and contrast different kinds of scenarios. Here we do that all the time with cases. Again, the logical reasoning section really tested people's ability to pick apart someone else's analytical reasoning . . . and that's all the judges' opinions are, are samples of good and bad logical thinking. Those skills are really valuable. And with reading comprehension, you really need to have a good attention span to stick with some of the cases you're studying. ... Can you sit through an incredibly dull piece of literature and extract information that you need to out of it? I'd say the LSAT is a great indicator of someone's ability to perform well at law school. ${ }^{405}$

Another White male in upper division echoed this view:

I think you can't beat the LSAT up, alluding again to the messenger. You don't beat the messenger because it brings a message you don't like. Because the LSAT tests . . the skills I most value in interacting with my classmates ... and when I find it here, it unites, it coalesces, it forms friendships because it's a

with Student No. 103, supra note 225 (White female); Interview with Student No. 114, supra note 180 (White male); Interview with Student No. 134, supra note 239 (White female). Of these students, only 2 favored dropping the LSAT altogether. See Interview with Student No. 65, supra note 199; Interview with Student No. 66, supra note 181. One student thought that the LSAT should be race-normed to account for differences in group performance. See Interview with Student No. 59, supra note 189. After these interviews were conducted, two members of the Boalt faculty, Linda Krieger and Marjorie Shultz, performed a validity study of grades and LSAT scores as predictors of performance in law school after the first year. Analyzing data for Boalt students admitted when affirmative action was used, they found that heavy reliance on LSAT scores most heavily burdened Black applicants and that such reliance was "disturbing" because of "the steep decline in the predictive validity of LSAT score" for this group after the first year of law school. Linda H. Krieger \& Marjorie M. Shultz, Validity of LSAT Scores \& Undergraduate Grade Point Average in Predicting Law School Performance Beyond the First Year 39-42 (June 2000) (on file with author). By contrast, the LSAT's predictive power was strongest and most stable for Chicano students, and its predictive power for Asian-American students was weak during all three years of law school. Id. at 31 (Figure 4).

403. See, e.g., Interview with Student No. 134, supra note 239.

404. Interview with Student No. 45, supra note 195.

405. Interview with Student No. 120, supra note 182. 
certain kind of thinking that I think can be relied on, as unpopular as that sounds.... I think the LSAT does test for a type of thinking that is valuable and unites across the different subgroups. ${ }^{406}$

This student went on to insist that academic administrators had concealed the racial gap in LSAT scores, precisely because the test nueasured important differences in ability, saying "Georgetown University finds out that the individuals being admitted have significantly lower ... LSAT scores on average, and they were coming from certain class or race of applicants. ... That same information isn't being released at Boalt, and I want to know why." 407

\section{c. The Adequacy of the Law School's Response to Changes in Admissions Policy}

Because students offered different justifications for affirmative action and did not share the same definition of merit, they often had quite distinctive expectations about how the administration should respond to changes in the admissions policy. A student of color in the first-year class criticized the law school for "overcomplying" with the affirmative action ban and took the Admissions Committee to task for "not even looking at other issues that could be related to race." ${ }^{408}$ A White woman in the first-year class said that "we haven't seen much movement or much commitment on the part of the faculty as a whole," adding that:

There's no excuse for Boalt sitting back and saying "We can't do anything." It took the administration and faculty long enough, when they were forced by students essentially, to redress this issue in a creative way. I think that needs to happen every year until we are achieving something more like the diversity we had. ${ }^{409}$

A White woman in her third year of law study described the faculty as divided between those who opposed affirmative action, those who supported it, and those who were caught in the middle:

I think that some portion of the Boalt Hall faculty is opposed to affirmative action and thinks that we need to really go back to looking at merit.... [P]eople overvalue the extent to which your LSAT scores really measure merit, and a lot of people are sort of stuck at that mode. I think that is one huge category of the Boalt Hall faculty, and they coincidentally happen to be the people who are less willing to talk about race in their classes and less likely to want to talk to students after class. I think that there is another huge set of the faculty that is just scared to get in trouble and be viewed as being so radical or whatever. I think there are the people who are

406. Interview with Student No. 52, supra note 196.

407. Id.

408. Interview with Student No. 50, supra note 205.

409. Interview with Student No. 8, supra note 190. 
the outright racists and then there are the people who are really scared and there is the small group of the faculty who I think wants to have some guts and do something about it and are largely paralyzed. I think the Dean has not provided much leadership..$^{410}$

On the other hand, one student pointed out that Boalt had been the captive of political events outside of its control and did not think it was fair to blame the administration or faculty for what had happened:

It is the Regents who did this, right? The Regents are a statewide body appointed by the Governor who control the University. It's not like Dean Kay can really just tell the Regents to stuff it. Certainly, she can try to work with them and try to be a little creative with it, with the rules and things, but I don't really like the idea of my Dean trying to circumvent what the voters of the state of California indirectly told her to do. I don't think that's her role. I think that if public opinion wants to change the way things are, it should be directed at the political arena, not the administrative.... It disappoints me that people are basically trying to shoot the inessenger in this situation. ${ }^{411}$

Overall, students were torn between a view that Boalt was bound by its nature to coinply with the law and a view that the law school could be creative in coinplying because of the inherent indeterminacy of legal principles.

\section{d. Normative Ambiguity and Shifting Support for Affirmative Action}

Students were far from unified in their views of affirmative action policy. Consistent with Orfield and Whitla's findings in their survey of Harvard and Michigan law students, a sizable majority of Boalt students favored affirmative action. The sample here is too sinall to be definitive, but it is worth noting that only about two-thirds of the students at Berkeley endorsed the policy compared to eighty percent at Harvard and Michigan. ${ }^{412}$ Perhaps the dismantling of the program weakened support for race-conscious admissions or enabled individuals to express their doubts and opposition openly. Those who supported affirmative action offered different normative justifications related to distributive justice, corrective justice, and inclusive pedagogy. Several students arguing for affirmative action singled out Boalt's unique role as a public institution producing future leaders in a diverse state.

Although the sample size was small, there did appear to be some correlation between race and one's preferred admissions policy. Only White and Asian-American students supported a colorblind policy based solely

410. Interview with Student No. 45, supra note 195.

411. Interview with Student No. 68, supra note 205.

412. See Orfield \& Whitla, supra note 124, at 25 tbl.22. 
on academic qualifications; these students come from groups that have alleged that affirmative action wrongly displaces them. Students who advocated economic disadvantage as a substitute for race all belonged to groups that have benefited from consideration of this factor: Whites, Latinos, and Asian Americans. Black students, by contrast, were reluctant to weigh socioeconomic status, even in conjunction with race. Thus, selfinterest arguably played some role in policy preferences, though one White student expressed support for affmiative action despite her own experience of displacement. She added, however, that she had not been severely burdened because she still had gained admssion to selective institutions.

The manner in which the policy at Boalt was changed created uncertainty about whom to hold accountable for the small number of Blacks and Latinos in the first-year class. Insofar as the law school had been required to revamp its policies by the Regents and the voters, some students saw the question as primarily a political one. However, because Boalt itself implemented the policy, other students blamed the Dean and faculty for "overcomplying" and not being "creative." In general, students did not discuss how the action of the Regents and voters might have impinged on the faculty and administration's sense of autonomy. The impact of high-profile politics on academic freedom and the discretion to make policy was generally not mentioned as a factor in evaluating the adequacy of the school's response.

\section{IV.}

The Unfulfilled Promise of Diversity and Legal Education: The LESSONS OF BOALT HALL'S EXPERIENCE

When I began this interviewing project, I adopted the perspective evident in much of the research on diversity in higher education: I focused on how changes in the composition of the student body might affect legal study, but I did not fully consider how competing conceptions of legal trainimg might influence perceptions of the relevance of diversity. To address the impact of diversity without confronting the complexities and contradictions of legal education is itself an analytical error that marginalizes the significance of race. After reading the transcripts, it became clear to me that no monolithic vision of legal education exists and that students arrive with disparate expectations about what law school will be like. These initial beliefs in turn are shaped and molded in important ways by the experience of legal education. Race is not merely an add-on to legal pedagogy, but rather one component in a larger debate about the meaning of law, legal education, and the legal profession. To their credit, many of the Boalt students who participated in this study were forthcoming not only about their views on race but also their perceptions of the educational process. Their candor and insight have made it possible to consider how 
internal conflicts over the meaning of legal education both help and hinder diversity.

Justice Powell's opinion in Bakke adopts a particular model of learning to justify diversity in higher education. Under this model, a substantial amount of education occurs through interaction with one's peers, who share unique personal experiences and histories. Much of legal education militates against this inage of the learning process. A substantial number of students arrive at law school by default; they see the degree as a way to postpone entering the real world for three years while inarkedly enhancing their earning potential. Precisely because of their detachment, these individuals may be reluctant to share intimate experiences in or out of the classroom. After sixteen years of education, they have coine to separate their innermost selves from their educational choices. Success in school involves technical mastery that will win respect and remuneration from others; it requires no profound personal commitnent. The alienation of these students ${ }^{43}$ can make it hard for their nore committed and engaged peers to feel comfortable sharing their history and experience.

At the outset, then, students seem quite differently situated with respect to their interest in and capacity to participate in the interchange at the heart of Powell's pedagogy of diversity. Law schools are not structured to overcome this initial reluctance. During the first year, students must attend a standard set of courses, regardless of their personal interests. Schools generally rely on large classes to educate substantial numbers of students at relatively low cost. Powell has been criticized because his nodel of caseby-case, discretionary admissions depended on a staff with resources like those at Harvard to review its applicant pool. ${ }^{414}$ But his vision of pedagogy also may depend on institutions with the wherewithal to administer a number of sinall, intensive seminars. ${ }^{415}$ As with undergraduates at an impersonal institution like Berkeley, these intimate settings may be critical in permitting students to cross racial and ethnic boundaries. ${ }^{416}$ For law schools that rely heavily on revenues from tuition, however, large, impersonal classes are a permanent fixture, one that is critical to financial survival.

413. For an earlier account of alienation and indifference among law students, see Alan A. Stone, Legal Education on the Couch, 85 HARv. L. REv. 392, 426-27 (1971).

414. See Nicholas lemann, The Big Test: The Secret history of the American MERITOCRACY 211 (1999).

415. See Frances Lee Ansley, Race and the Core Curriculum in Legal Education, 79 CAL1F. L. REv. 1511, 1527 (1991) ("The level of trust, resulting candor, and subtlety that a group of twelve can establish is radically different from that achievable by a group of sixty-five."); see also Alice $\mathrm{K}$. Dueker, Diversity and Learning: Imagining a Pedagogy of Difference, 19 N.Y.U REv. L. \& Soc. Change 101, 134 (1991-92) (noting the "hard choices about the use of law school resources" that the shift to a pedagogy of diversity would require).

416. See supra note 165 and accompanying text. 
Even at institutions with the means to humanize the law school experience, very often the curriculum and structure of classes remain impersonal. In the minds of some faculty and administrators, the very impersonality of legal education forms part of a student's preparation for entry into the profession. For them, "thinking like a lawyer" means learning to transcend one's personal experience by adopting abstract reasoning and universal techniques for argument. A student's background and experience are a distraction to be overcome, rather than a resource to be developed through the instructional process. ${ }^{417}$ When "a spirit of fire" asked him whether legal study required him to sell his birthright for a mess of pottage, Justice Oliver Wendell Holmes answered:

No man has earned the right to intellectual ambition until he has learned to lay his course by a star which he has never seen-to dig by the divining rod for springs which he may never reach. In saying this, I point to that which will make your study heroic. For I say to you in all sadness of conviction, that to think great thoughts you must be heroes as well as idealists. Only when you have worked alone-when you have felt around you a black gulf of solitude more isolating than that which surrounds the dying man, and in hope and in despair have trusted to your own unshaken will-then only will you have achieved. Thus only can you gain the secret isolated joy of the thinker. . . . ${ }^{418}$

In the Holmesian tradition, personal relationships are a distraction, not a boon, to law study, and students' inability to transcend prior experience becomes a potential obstacle to professional attainment.

Students perceive the classroom as a hierarchical setting, one in which their views matter considerably less than the professor's. ${ }^{419}$ As Karl Llewellyn, a leading legal educator at Columbia and the University of Chicago, counseled entering law students in a famous series of lectures: "The hardest job of the first year is to top off your common sense, to knock your ethics into temporary anesthesia. Your view of social policy, your sense of justice-to knock these out of you along with woozy

417. See, e.g., Anthony D'Amato, The Decline and Fall of Law Teaching in the Age of Student Consumerism, 37 J. LEGAL Educ. 461, 462 (1987) ("Teaching is an attempt to change the student's mind.... [T] here is no doubt that teaching ... is a deliberate form of interference with how the student thinks."); Ruta K. Stropus, Mend It, Bend It, and Extend It: The Fate of Traditional Law School Methodology in the 21st Century, 27 Loy. U. CHI. L.J. 449, 479 (1996) ("A learning methodology that does not involve some degree of educational stress, is not a methodology that encourages growth.").

418. Oliver Wendell Holmes, The Profession of the Law, in Collected Legal Papers 29, 31 32 (1920).

419. For a forceful and pointed critique of the hierarchical structure of legal education, see Duncan Kennedy, Legal Education as Training for Hierarchy, in 2 THE HistoRY OF LEgAL EDUCATION IN THE UNITED STATEs 889 (Steven Sheppard ed., 1999). For a reply to an earlier version of Kennedy's critique, which defends the virtues of the Socratic method when properly used, see Stone, supra note 413, at 406-18. 
thinking. . ." ways that undermine Powell's vision of a pedagogy of diversity. The broad-ranging values that students bring to the classroom can be dismissed as irrelevant. ${ }^{421}$ As a result, some find the process of legal education "intellectually stunting" because the focus on universal methods and abstract rules of law obscures the social and ethical context in which decisions are made. . $^{22}$

The fear that students' personal concerns will disrupt the learning process can lead professors to avoid certain topics and issues. Often, these relate to race and gender, areas in which faculty fear that emotions will divert students from mastering doctrine and irreparably damage the classroom climate. The special contributions that women and students of color can make by dint of their unique experiences thus become impediments, not assets, to the learning process. The dominant model of pedagogy is rooted in Christopher Columbus Langdell's efforts to convert law into a respectable academic disciphne by treating it as a kind of "science." 423 This scientific model continues to influence modern legal education through modified use of the Socratic method, which treats cases as data and requires students to apply deductive logic to extract key doctrinal principles. ${ }^{424}$

Two members of the Boalt faculty, Angela P. Harris and Marjorie M. Shultz, have written eloquently about their struggle to recognize the role of emotion in intellectual endeavors, including legal education. ${ }^{425}$ According

420. K. N. Llewellyn, The BRamble Bush: ON OUR LAW AND ITS STUdY 101 (1930).

421. For similar findings in other studies, see Thomas L. ShafFer \& Robert S. Redmount, LAWYERS, LAW STUDENTS AND PEOPLE 181-82 (1977) (describing how professors teach law students to refrain from making value judgments); Kurt M. Saunders \& Linda Levine, Learning to Think Like a Lawyer, 29 U.S.F. L. REv. 121 (1994) (reporting on interviews in which first-year students noted "law school's tendency to dehumanize and ignore broader social implications"); see generally Charles R. McManis, The History of First Century American Legal Education: A Revisionist Perspective, 59 WASH. U. L.Q. 597, 657-58 (1981) (describing the continuing power of traditional models of legal education despite longstanding efforts to "broaden the subject matter and methodology of law study").

422. For another account of these concerns expressed by a law student at Temple, see William F. Kullman, Feminist Methodologies in the Law School Classroom: Listening for a Change, 3 TEMP. PoL. \& CIV. RighTS L. REv. 117, 119 (1994) (describing how classmates rejected a woman's effort to challenge the discussion of a rape case because she "had no business 'distracting' our class from "learning the law."').

423. For a discussion of Langdell's efforts to make law a scientific enterprise and their impact on legal education, see Thomas C. Grey, Langdell's Orthodoxy, 45 U. PITT. L. REv. 1, 12-13, 37-39, 4243, 50-53 (1983); Robert SteVENS, LAW School: Legal EdUCATION IN AMERICA FROM THE 1850's TO THE 1980's, at 52-55 (1983).

424. See Angela P. Harris \& Marjorie M. Shultz, "A(nother) Critique of Pure Reason": Toward Civic Virtue in Legal Education, 45 STAN. L. REv. 1773, 1776-77 (1993) ("The notion that the study of law is and should be scientific has clung tenaciously, long after Langdell's narrow view of legal reasoning as something like geometry has been abandoned."); see also David S. Sokolow, From Kurosawa to (Duncan) Kennedy: The Lessons of Rashomon for Current Legal Education, 1991 Wis. L. REv. 969, 970-74 (describing how legal education stifles cultural and emotional diversity).

425. See Harris \& Schultz, supra note 424, at 1774. 
to Harris and Shultz, the links between law and emotion are undeniable though unacknowledged:

[L]aw and legal institutions seem deeply and inevitably infused with emotion. Law legitimates official coercion. It designs institutions and processes for the resolution of conflict. It prescribes norms for conduct. It expresses and effectuates social ideals of fairness and justice. These functions-central in our society-cannot help but evoke strong emotions. Moreover, legal rules and institutions incorporate our deepest concerns about culpability and desert, free will and responsibility, equality and freedom. These ideals are generally agreed upon at the highest levels of abstraction, but their implementation is deeply problematic. Given these realities, it seems that emotion could not possibly be eliminated from the domain of law. ${ }^{426}$

This study illustrates that very point. To contain difficult issues of racial and gender justice, faculty sometimes rush to an easy moral consensus. They establish the wrongfulness of intentional discrimination but mask intensely felt differences about how to implement principles of racial equality. For instance, professors and students readily agree that racism in the housing market is despicable, but say far less about what role, if any, the government can play im promoting residential imtegration.

According to Harris and Shultz, the false dichotomy between emotion and reason distorts and impoverishes law school teaching. For example, first-year Constitutional Law instruction at Boalt now focuses heavily on federalism, separation of powers, and the Commerce Clause, in part because of the faculty's fear that the more interesting material on due process and equal protection would "rile students up' too much before they ... learned proper (unemotional) legal analysis." ${ }^{\prime 27}$ The consequences of the decision are reflected in this study. Students complain that the class should be called Commerce Clause Law instead of Constitutional Law. They report that even when a case like Katzenbach implicates race, these issues are suppressed by a narrow and abstract focus on the scope of congressional power. As a result, students often feel uncertain about the very doctrinal mastery supposedly advanced by excluding potentially volatile subjects. The artificial line drawn between the question of congressional power under the Commerce Clause and the Fourteenth Amendment leaves students wondering why private discrimination could not be barred under the Equal Protection Clause.

Similarly, in Baby $M$., the sensitive issues related to gender, motherhood, and personhood can be suppressed by focusing on issues of commodification that equate surrogacy contracts with a market in vital organs.

426. Id. at 1777-78 (footnote omitted).

427. Id. at $1783 \mathrm{n} .22$. 
Although this approach highlights important considerations about the moral limits of free-market ideology, the discussion bewilders and frustrates some students. Framing the case in these terms makes gender irrelevant because men can sacrifice a kidney just as women can give up a child. Yet, this symmetry may be artificial. In general, the prospect of selling or buying an organ is an abstraction removed from students' lives, while childbearing and parenthood are real choices that most of them will confront. Students recognize that their views about universal and profoundly personal decisions can be influenced by experience. In fact, some students become concerned that they too readily overlook the special pain of losing a child or being unable to conceive one, in part because most of them have yet to become parents. Moreover, the analysis diverts students' attention from the unequal positions of men and women with respect to both their economic options and their physical investment in childbearing. Finally, for at least one devout Christian student, the moral issues are clouded by a deep sense that the most fundamental value judgment, that of treating babies and organs as fungible, was made without hesitation or discussion. ${ }^{428}$

In some cases, professors avoid polarizing topics by dropping them from the curriculum. As this study reveals, one course in which that temptation is considerable is Criminal Law. Even when faculty attempt to use philosophical abstractions to contain heated discussions about race and gender, emotions break through and influence the discussion. In 1988, Nancy S. Erickson reported that casebooks in Criminal Law regularly omitted issues of particular concern to women, including rape and spousal battering. ${ }^{429}$ Since then, casebook revisions have made it increasingly difficult to avoid these subjects. ${ }^{430}$ At Boalt, professors have regularly included "hot button topics that trigger extreme reactions and counterreactions." 431 They have adopted different approaches to these cases, presumably to foster constructive discussion. In the area of race, the urge to elide issues seems great. Students recall that one professor muted racial questions by changing the identity of Blacks to Jews in hypotheticals. Even the professor who drew on his own personal experience to illuminate the Goetz case did not reveal the race of the skaters who frightened him until a student asked him. When these strategies of elision and avoidance failed, race sometimes entered the classroom with a vengeance. One Black student, for example, recalled the discussion of Goetz in his class as the "most

428. Interview with Student No. 52, supra note 196. This student's views were discussed above. See supra text accompanying note 219.

429. See Nancy S. Erickson, Sex Bias in Law School Courses: Some Common Issues, 38 J. LEGAL EDuc. 101, 104 (1988).

430. See James J. Tomkovicz, On Teaching Rape: Reasons, Risk, and Rewards, 102 YALE L. J. 481, 481-84 (1992) (describing how he included rape law in his Criminal Law class for the first time in 1992, although he had been teaching the course for 10 years).

431. Id. at 505 . 
egregious incident" he had witnessed at Boalt Hall. The resulting "diatribe" and "litany of attacks" may have reinforced professors' anxieties that these discussions inevitably will "cross the borders of legitimate, respectful, professional discourse" and "lead to tension, hard feelings, and censorship." 432

Gender issues also produced intense debate, and in some instances, students refrained from expressing their views to avoid being labeled "politically incorrect." Interestingly, however, students portrayed the dynamic of tension and conflict differently for race than for gender. With Goetz, students generally focused on whether the professor handled the case appropriately by addressing racial biases and stereotypes without reinforcing them. The requirement to avoid any semblance of racist thinking was seen as a general moral obligation. Racism had to be confronted and condemned in order to be fully eradicated. Students did not link this obligation to a perception of racism as a pervasive phenomenon that taints the lives of many students in the class, so that they are marginalized by clumsy treatment of the cases. When students recalled domestic violence and rape cases, however, they focused on classmates as readily as on the professor. Perhaps because of the even split of men and women, male classmates were more likely to express views that some women found offensive. In addition, some women in the study emphasized the widespread nature of sexual violence and the likelihood that boyfriends, husbands, or strangers had victimized some members of the class. They characterized insensitivity by faculty and male students as not only morally repugnant but also pedagogically crippling. Precisely because the cases so directly implicated women's lives, students deemed this handling to be a destructive, not robust, exchange of ideas.

The classroom experience is in many ways the centerpiece of the first year of law school, the place in which the bulk of socialization into the profession takes place. Scott Turow describes how first-year classes made clear to him that he and his peers self-selected into

an intensely competitive profession in which there are winners and losers every time the jury returns, or the judge speaks.... But we carried those feelings with us at all times. ... And especially within the classroom, where the professors' questions acted to pit the 140 of us against each other, our aggressions were bound to be excited, whether they were acknowledged or not. ${ }^{433}$

Students at Boalt echoed these sentiments about large lecture classes, remembering the experience as "Ionely and scary." 434 While some try to reassure themselves that their classmates are "professional," others

432. Id. at 500 .

433. SCOTt Turow, ONE L 75 (1977).

434. Interview with Student No. 52, supra note 196. 
condemn them as "self-righteous" and "condescending." 435 In a highly competitive atmosphere in which a lack of feedback exacerbates students' anxieties and insecurities, some of the antagonisms develop along race and gender hines. Some students resented the assumptions about race that their peers brought to the classroom, while women reported feeling silenced by outspoken, aggressive men. ${ }^{436}$ The result can be a chilling effect that leaves students unable to trust one another enough to share ideas and experiences that are deeply personal.

Faculty-student contacts outside of class do not mitigate the sense of impersonality that emerges during the formal instructional process. Faculty and students seldom communicate on more than a superficial basis. Because mentoring relationships are rare, students do not see faculty as a source of guidance or assurance as they adapt to the demands of legal education and plan their career. With some notable exceptions, students perceive professors as largely inaccessible because they must prioritize research to preserve their academic reputations. ${ }^{437}$ Women and people of color on the faculty are hardly immune to these pressures. In fact, because of their small numbers, these professors often find themselves overcommitted and thus unavailable as mentors. As a result, students who identify with these faculty and might feel particularly comfortable seeking them out do not do so or feel frustrated when they do. The social distance between faculty and students erects yet another barrier to the robust exchange of ideas that Powell hoped for.

Other features of first-year life mimic rather than counteract the values communicated in the classroom. Study groups, for example, form to compete for the hierarchical rewards that will accrue from mastering

435. Id.; Interview with Student No. 53, supra note 195.

436. For other descriptions of how women feel silenced in law school classrooms, see, for example, Taunya Lovell Banks, Gender Bias in the Classroom, 38 J. LeGal Educ. 137 (1988); Judith D. Fischer, Portia Unbound: The Effects of a Supportive Law School Environment on Women and Minority Students, 7 UCLA WoMEN's L.J. 81 (1996); Lani Guinier et al., Becoming Gentlemen: Women's Experiences at One Ivy League Law School, 143 U. PA. L. REv. 1 (1994); Suzanne Homer \& Lois Schwartz, Admitted But Not Accepted: Outsiders Take an Inside Laok at Law School, 5 BERKELEY WoMEN's L.J. 1 (1989-90); Catherine Weiss \& Louise Melling, The Legal Education of Twenty Women, 40 Stan. L. Rev. 1299 (1988); Stephanie M. Wildman, The Classroom Climate, in Looking at LAw School 75 (Stephen Gillers ed., 4th ed. 1997); Stephanie M. Wildman, The Question of Silence: Techniques to Ensure Full Class Participation, 38 J. LEgaL Educ. 147 (1988).

437. Boalt is not the only institution in which students report that faculty are largely inaccessible. Harvard Law School recently commissioned a survey of its students and alumni. In response to complaints about "aloof, hard-to-find professors" and "big, impersonal classes," Harvard has taken steps to reduce its relatively large student-faculty ratio. David Abel, Harvard Looks at Student-Teacher Ratio, Smaller Classes Recommended, Boston GloBE, Dec. 28, 1999, at B1. The survey was commissioned in the wake of findings that Harvard students were among the most dissatisficd with their legal education. See Katherin S. Mangan, Harvard Law School Tries to Figure Out Why Many of its Students Aren't Happy, ChroN. OF Higher Educ., Oct. 1, 1999, at A56; James Bandler, At Harvard Law, Next Case Study is Student Morale, Boston Gzobe, July 11, 1999, at A1. 
doctrine and pleasing the professor. Far from being an occasion for sharing, the groups become another forum for one-upmanship, or as one student in this study described them, "mercenary." Scott Turow, in chronicling his first year at Harvard Law School, chillingly describes his rejection of a plan to share his study group's outline with others: "II want the advantage,' I said. 'I want the coinpetitive advantage. I don't give a damn about anybody else. I want to do better than them." 438 As a result of this winner-take-all orientation, even in study groups, where peers arguably are learning from each other, Powell's pedagogy of diversity will be very much in the background. With a focus on abstract legal reasoning, members will find little reason to "waste" time discussing their values or personal experiences. Students expect to compare and consolidate their understanding of the lectures, not bring to bear their unique histories and backgrounds. Diverse membership in study groups will be deemed important only insofar as the instructor makes race or gender a salient issue in the course. Otherwise, concerns about the qualifications of students of color may lead to their being excluded from groups that fear losing a competitive edge. The interviews here reveal that some Black students at Boalt formed a study group together, even though they did not share the same schedule. Despite the obvious advantages of working with classmates who were learning the same material, at least one Black student was not invited to participate in other groups and did not feel able to invite himself.

Much of the socialization process in law school takes place during the first year. ${ }^{439}$ As a result, certain "habits of thought" that can interfere with a pedagogy of diversity are already entrenched by the second and third years of law school. ${ }^{440}$ Even so, extracurricular activities, typically organized and run by upper-division students, offer one area in which students can choose to model pedagogical hierarchy or resist it. ${ }^{441}$ Some extracurricular activities replicate the competition to best one's peers in the quest for academic recognition. The California Law Review, for example, is a prestigious journal open only to those who win a writing competition. Applicants must demonstrate their analytical strengths by addressing a pre-selected topic, rather than one that reflects their personal interests. The applicant's merits are judged by members who distinguished themselves in the same

438. TUROW, supra note 433, at 285.

439. See Saunders \& Levine, supra note 421, at 182 (noting how first-year student interviews demonstrated how they learned to think like lawyers, beginning "in the bounded world of the classroom" and "shift[ing] from idealism to disenchantment and disillusionment with the legal system and the role of lawyers" after their first summer of work experience).

440. For a discussion of the habits of thought that become entrenched in legal education and hamper the impact of diversity, see Peter M. Shane, Why Are So Many People So Unhappy? Habits of Thought and Resistance to Diversity in Legal Education, 75 IowA L. REv. 1033 (1990).

441. See Winston B. Crisp, Student Organizations 1945-95, 73 N.C. L. Rev. 830 (1995) (describing the proliferation of student organizations at the University of North Carolina Law School that accompanied the diversification of the student body). 
competition in earlier years. After an applicant is accepted for membership, there is a new round of competition, this time for spots on the editorial board. Members admitted after their first year must demonstrate their intellectual ability and commitment during the second year to win one of these coveted spots in the third year. Traditional activities like $C L R$ enhance a student's résumé and serve primarily to reinforce the skills of abstract reasoning and legal writing learned in the classroom. Students can develop an area of their own interest by writing and publishing a note, but many members never have their work published. Instead, they evaluate and refine other people's ideas, applying their general talents in critical thinking, research, and writing. Because much of their effort is behind-thescenes editing and cite-checking on assigned manuscripts, members often treat these activities as a credential rather than a calling.

By contrast, other extracurricular commitments offer a haven for those who feel that the regular curriculum marginalizes their interests and values. Viewed as nontraditional in nature, these activities provide a way for some students to find fulfillment and promise in law despite their frustration with the abstraction of their academic courses. Student organizations sometimes devote themselves to topics, such as the problems of the poor and disadvantaged, that form a peripheral part of the core curriculum. The Berkeley Women's Law Journal typifies this sort of commitment, and not only its substantive mission but also its structure challenge the dominant paradigm of legal education. By emphasizing collaboration and egalitarian working relationships, $B W L J$ attempts to demonstrate that highquality scholarship can be produced without intense competition and hierarchy. Despite efforts to create an alternative to the traditional model, however, the adversarialism so pervasive in law school life can reassert itself when difficult issues are at stake. For example, when women of color challenged an editorial decision, the arguments became so contentious that the dissenters wound up leaving $B W L J$. In a climate in which hard bargaining is the norm, even an organization committed to egalitarianism and inclusion can fail to find common ground among its members.

Other activities focus on moving beyond the classroom to serve chents or the community. For instance, the Berkeley Law Foundation sponsors summer internships so that students can work on public interest projects, and the Workers' Rights Clinic allows students to serve clients of modest means with real-life problems. These extracurricular commitments provide students with a way to explore their professional identity in terms of relationships to people, rather than solely in terms of doctrinal analysis of cases. Students learn about teamwork, as well as the dangers of privileging abstract concepts over concrete needs. ${ }^{42}$ But, whether reinforcing or

442. See Beverly Balos, Learning to Teach Gender, Race, Class, and Heterosexism: Challenge in the Classroom and Clinic, 3 HAstings WOMEN's L. J. 161, 165-71 (1992) (describing how clinical 
resisting, student activities in the second and third year are defined in relation to the dominant paradigm of legal education established in their firstyear classes.

Interestingly, and perhaps reflecting the impersonality of legal education, there has been little inquiry into the nature of law school friendships. In general, friendships are simply presumed to offer support networks in the short run and professional networks in the long run. The current research reveals that a significant minority of students do not forge close friendships with their classmates. Their comfort and support come through associations outside the school that enable them to keep their emotional distance from life at Boalt. Indeed, one woman described her choice of friends as a kind of "denial" or withdrawal from her status as a law student.

In keeping with Antonio's findings, ${ }^{443}$ students generally report that their friendships are diverse but that the law school is balkanized to some degree. Antomo found that diverse friendship groups were less intimate than homogeneous ones. This study does not permit any inferences about whether the heterogeneity of friendships at Boalt correlated with superficial relationships. There is, however, at least some suggestion that gender segregation enabled some students to be more authentic and less inhibited with one another, for example, by "being crude."

Relatively few students saw their friendships at Boalt as a source of future professional contacts. Perhaps, as law firms have grown larger and more impersonal, people do not expect to benefit from an "old boy's network" but instead anticipate that they will be judged on their smarts, stamina, and savvy by partners and associates whom they have yet to meet. ${ }^{444}$ Students of color more often expressed the view that their social contacts at Boalt were a way to develop skills for dealing with fellow professionals in predominantly White environments. As one Black student explained, minority students could not afford the luxury of selfsegregation. At the same time, students of color may have anticipated some future contact with classnuates they met in racial and ethnic orgamizations. Given the sniall number of Blacks and Latinos in elite schools and exclusive law firms, some of their fellow members were quite likely to become leaders in the bar and in their communities. Interestingly, then, networking may have been of greater importance to non-White students, who would

experiences help students to learn to listen to clients and to value personal experience, emotion, and stories); Charles R. Calleros, Training a Diverse Student Body for a Multicultural Society, 8 LA RAzA L. J. 140, 148-49 (describing how a student became so oriented to maximizing statutory benefits that he failed to attend to the client's wish to work full-time, even though it reduced her benefits).

443. See Antonio, supra note 114.

444. See Alex M. Johnson, Think Like a Lawyer, Work Like a Machine: The Dissonance Between Law School and Law Practice, 64 S. CAL. L. Rev. 1231, 1240-42 (1991) (describing "the growth and proliferation of large law firms" and the concomitant decline in a bonding tradition that led to loyalty, stability, and a sense of "family"). 
inhabit a tighter-knit professional world, than to White students who were joining burgeoning and transient law firms.

The normative uncertainty that characterizes the legal and pedagogical debate about affirmative action also affects students' perceptions about the policy. This study reveals the limitations of research that simply asks students to indicate whether diversity is a positive or negative feature of their education. Given the opportunity to expand on their views, a substantial number of students express ambivalence and recognize that under current conditions, there is no perfect solution to the question of access for traditionally underrepresented groups. Students struggle with the relative importance of race and socioeconomic status, uncertain of how to weigh these distinctive notions of disadvantage. Very few believe that numerical indicators alone provide the best measure of merit, but inany are unsure about how to put these quantitative measures in context and give applicants a human face. In that sense, affirmative action reveals another, larger dilemma: many do not believe there is an ideal way to measure "desert" or "entitlement," regardless of race. A valuable asset, a place in Boalt's entering class, must be allocated with limited information and scarce administrative resources. Affirmative action highlights the difficulties of sorting applicants into neat queues, but the problem transcends race and ethnicity and goes to the heart of defining a meritocracy. ${ }^{445}$

The normative ambiguity surrounding affirmative action is exacerbated by the uncertain fit between Powell's pedagogy of diversity and the process of legal education. Powell describes a model of learning that seems foreign to many law students, regardless of their race, gender, or views on affirmative action. According to Powell, students are engaged in a cooperative enterprise. Yet many students find legal education to be hierarchical and competitive, rather than a process of mutual exchange. Although rates of attrition in law scliool are quite low, law students develop ways of withdrawing intellectually and emotionally from the life of the institution. ${ }^{446}$ These patterns of detachment are by no means confined to women and people of color, as this study demonstrates. Gender and race affect the ease of assimilating to the law school's requirements, but all students are affected to some degree. ${ }^{447}$ Arguably, an "identity crisis" is inherent in the professional socialization process. Law schools take a heterogeneous group of students and convert them into people who increasingly think alike. As a result, "changes in views about legal education reflect the ease or difficulty with which students meet the

445. For an account of how affirmative action has revealed the limitation in relying single-mindedly on standardized testing, see LEMANN, supra note 414, at 198-211.

446. For an early account of how legal education can erode students' self-esteem, prompting

"withdrawal, depression, and disengagement," see Stone, supra note 413, at 426-27.

447. See id. at 454-56; Dueker, supra note 415, at 104-05. 
obligations of the law student role and are personal adaptations to anticipated success." ${ }^{\prime 48}$ Critics argue that while a certain amount of effacement is necessary to turn lay people into lawyers, the socialization process in law school is unnecessarily dehumanizing. ${ }^{449}$

Even so, all of these commentators seem to agree that part of the current mission of legal education, whether wrongly or rightly, is to transcend difference to produce a standardized version of the professional lawyer. To a significant extent, this image is at odds with the pedagogy of diversity that Powell envisioned in Bakke, a learning process that depends on difference to enrich understanding. Ironically, Powell singled out law schools as institutions in which his diversity-oriented model is especially valuable, given the range of clients and problems that graduates will confront. Students who arrive at law school believing that they can make unique contributions based on their background and experience are likely to be disappointed. They soon discover that their values and attitudes are at best irrelevant and at worst an obstruction to learning to think like a lawyer. Raising personal views in class is apt to be seen as a blunder or a diversion: the student is either disagreeing with the professor or distracting the class from learning the law. This dissonance between traditional legal education and a diversity-oriented model leaves students admitted under affirmative action programs vulnerable to a sense of delegitimation. While other students merely resent the self-effacement required to become a professional, women and students of color find that the privilege of voice that was to come with inclusion, indeed was a critical justification for inclusion, has been denied them.

After reading this study, one might be tempted to conclude that diversity does not work. This conclusion would be premature for several reasons. First, the sample is quite small, and the study was performed at a single law school. Moreover, the interviews were done at a moment in Boalt's history when the challenges of diversifying the student body seemed particularly intractable. Finally, the research focused on the firstyear experience, a time when students had hittle autonomy to select classes that fit their learning styles and personal interests. As one student put it: "In the first year ... there's a fixed menu of courses that you've got to take, you're going to be crammed in these large courses whether you like it

448. Audrey James Schwartz, Law, Lawyers, and Law School: Perspectives from the First-Year Class, 30 J. Legal Educ. 437, 468 (1980).

449. See Elizabeth Dvorkin et al., Beconing a Lawyer: A Humanistic Perspective on Legal Education and Professionalism (1981); Dueker, supra note 415, at 101; Kim Economides, Cynical Legal Studies, in Educating for Justice: Social Values and Legal Education 26 (Jeremy Cooper \& Louise G. Trubek eds., 1997); B.A. Glesner, Fear and Loathing in the Law Schools, 23 Conn. L. Rev. 627 (1991); Shauna Van Praagh, Stories in Law School: An Essay on Language, Participation, and the Power of Legal Education, 2 Colum. J. Gender \& LAW 111 (1992). 
or not, just make the best of it." ${ }^{3450}$ The initial law school experience could be especially disorienting, and students may go on to find space to express their identities and perspectives in small, special-interest seminars in the second and third year. Still, these interviews suggest that the introduction to law study can be dehumanizing and demoralizing for all students. As a result, they find it hard to reach out to one another to capitalize on the promise of Powell's vision of a diverse pedagogy. The impact of diversity is felt when differences become so profound that they cannot be contained through abstraction, and the sharing at the heart of Powell's model takes place mainly in extracurricular settings more informal and less competitive than the classroom.

\section{CONCLUSION}

So far, much of the research on diversity in higher education has focused on whether underrepresented students have adapted to the demands of advanced study based on measurements of student achievement, racial attitudes, and professional contributions after graduation. This work is admittedly valuable, but the Boalt study reveals that it also suffers from blind spots. These blind spots arise because researchers assume that higher education is a given, and that the problems of women and people of color are sui generis. Through in-depth interviews with students, this inquiry has shown that the nature of higher education cannot be taken for granted in studies on the impact of diversity. On the contrary, the structure of the pedagogical process can significantly influence previously excluded groups' opportunities to thrive and their classinates' ability to capitalize on the new perspectives they bring. The very processes of marginalization and alienation that harm the progress of women and minorities often reflect exclusionary educational practices that hurt others as well. For example, high rates of detachment and dissatisfaction are attributed to race and gender difference when, in fact, they are a byproduct of a hierarchical classroom experience that creates few winners and many losers. Whether this winner-take-all mentality is a healthy learning strategy is a question that implicates the entire student body, even if its burden falls most heavily on the already vulnerable.

The most prominent research on diversity in higher education tries to demonstrate that affirmative action is working because historically underrepresented groups are now assimilating to the demands of academic and professional life. What this research fails to consider is whether higher education is successfully adapting to the demands of a diverse student body and society. In general, there has been little effort to determine whether colleges, universities, and professional schools are implementing

450. Interview with Student No. 6, supra note 205. 
programs that draw on students' values and experiences and encourage a robust exchange of ideas with their peers. In law schools, at least, it seems likely that the traditional curriculum has changed only slightly in response to the dramatic changes in the demographic composition of the students served. As a result, it is easy to dismiss diversity as a fig leaf for affirmative action, a mere numbers game masquerading as a pedagogical theory. To a substantial degree, the vision of diversity-oriented education that Justice Powell envisioned in Bakke has remained a theory, seldom put into practice in institutions with large classes, a focus on abstract concepts and universal principles, and a hierarchical system of authority and rewards. Boalt, like other law schools, only incompletely fulfilled the promise of diversity, despite the growing heterogeneity of its student body throughout the late 1970s, 1980s, and much of the 1990s. As Boalt enters the new century, its opportunity to capitalize on student diversity has greatly diminished, but its obligation to reflect on and reform the pedagogical process remains. 
Appendix A

\section{PROTOCOL}

\section{PRELIMINARY MATTERS}

A. Greet the participant. Be sure to identify yourself and thank the participant for coming.

B. Ask the participant if he/she would mind if you turn on the tape recorder, and turn it on if he/she says it's okay.

C. Briefly explain the purpose of the study:

1. This interview is part of a study that will look at the impact, if any, of recent changes in Boalt's admissions policy on the educational atmosphere and social climate of the law school.

2. The interview consists of a series of questions that will deal with classroom experience, study groups, extracurricular activities, social life, and law school admissions policy.

D. Tell the participant that he/she should feel free to answer the questions in any way he/she wants and should ask for clarification if any question is unclear.

E. Remind the participant that as was stated in Professor Moran's letter, his/her identity will be kept completely confidential, he/she can end the interview at any time, and he/she can decline to answer any question that he/she would not be comfortable answering.

F. Ask if the participant has any questions and, if so, answer them.

G. Ask the participant to sign the informed consent agreement. Be sure to thank the participant for signing.

\section{BREAKING THE ICE}

A. Get some general background about the participant.

1. What did you do before you came to law school? 
2. Be sure to get undergraduate institution, major, graduate school, and previous work experience.

B. What made you decide to come to law school? Based on your law school experience so far, do you think you made the right decision? Why or why not?

\section{CLASSROOM EXPERIENCE}

A. Explain to the participant that this study is focusing on students' experiences in class during the first year of law school.

B. Ask the participant which professors they had during the first year. Refer to the sheet to be sure that all classes are covered.

C. Ask the participant which class was his/her small group.

D. Ask the participant to describe patterns of participation in large lecture classes. Find out whether students participated a great deal, whether the same students tended to participate, and, if so, who they were (men/women, white/persons of color). Ask whether the participant believes that all students felt included in the discussion. If so, ask how this sense of inclusion affected the discussion. If not, ask how this sense of exclusion affected the discussion.

E. Ask whether the patterns of participation were different in the participant's small group than in the large classes. Find out whether or not there was a greater sense of inclusion in small group than in large lecture classes. Ask why the participant thought these differences occurred or failed to materialize. If there were differences, ask how they affected the nature of the discussion. You should focus on whether an mclusive atmosphere proinotes discussion of a broader range of perspectives, including issues relating to race and gender.

F. Ask whether professors generally were concerned about including everyone in the discussion. Ask what steps, if any, professors took to encourage a broad range of participation. Ask whether the steps were successful, and why or why not. If professors differed in this regard, ask the participant to explain why he/she thinks professors had different attitudes about participation.

G. Ask whether the participant believes professors serve as role models, and why or why not. If the participant thinks professors do act as role 
models, find out what impact he/she thinks they had in this regard. Get examples, if possible.

H. Ask the participant to read the first of two preselected vignettes. Find out whether the participant studied the case in his/her class. If so, ask the participant to describe the nature of the discussion. If not, show the participant an alternative vignette from the list provided for the topic area.

I. Repeat the procedure with the second preselected vignette.

J. If the participant has not had any of the vignettes, ask him/her about a case that he/she remembers in which (gender/socioeconomic) issues were discussed. (Ask about gender when the vignette covered this area, or about socioeconomic status when the vignette covered this area.) Get a full description of the discussion. Then ask about a case where racial issues were discussed. Once again, get a full description of the discussion.

\section{STUDY GROUPS}

A. Find out whether the participant studied with a group or not during law school.

B. Ask the participant why he/she chose to study with a group or study alone, depending on the answer.

C. Find out whether the participant thinks that studying in a group plays an important role in the learning process? Why or why not? Find out what benefits, if any, he/she thinks there are in studying with a group. Or ask what benefits he/she thinks have been foregone by studying alone.

D. Ask whether the participant thinks people feel most comfortable studying with people like themselves. Find out how the participant thinks people define someone who is like them. What characteristics matter most?

E. Are most study groups homogeneous in terms of gender? Race? Other characteristics? What about the participant's own group, if he/she had one?

F. How does the composition of the group affect the nature of the discussion, if at all? How does the participant think discussions would differ, if at all, in groups that are all men, all women, or a mix of men and women? How does the participant think discussions would differ, if at all, in groups that are racially homogeneous and racially heterogeneous? How important 
are these issues in evaluating the learning process that goes on in study groups?

\section{EXTRACURRICULAR ACTIVITIES}

A. What extracurricular activities are you involved in at Boalt? How much time do you spend on these activities in an average week?

B. What made you decide to get involved in these activities? Are they primarily social activities or do you see them as part of your professional development? Do you expect to develop professional contacts through these activities that will help you in the future? Why or why not?

C. When you participate in these activities, do you think that men and women are equally involved? Are there equal numbers of men and women members? Are they equally likely to take leadership roles in the organizations? Why or why not?

D. Do these activities attract a racially and ethnically diverse group of students? What is the racial and ethnic breakdown of the membership? What is the breakdown of the leadership? Do you think that members of the student body feel equally free to participate in these activities, regardless of their race or ethmicity? Why or why not?

E. What impact, if any, do you expect the changes in admissions policy to have on extracurricular activities at the law school? If you expect changes to occur, how do you think that they will affect the average student at the law school, if at all?

\section{SOCIAL LIFE}

A. Who are your closest friends at Boalt? How did you nieet? What do you think you share in common with them? Do you expect to remain in touch with them after law school? If so, do you anticipate that the contact will be primarily social, primarily professional, or a mixture of both? Why?

B. Are your closest friends at law school mainly men, mainly women, or a mixture of both? Do you think that this pattern is purely coincidental, or do you think that it results from preferences for friends who are (male/female/both male and female)? 
C. Would you describe your closest friends at law school as racially and ethnically diverse? Why or why not? Why do you think that you have this pattern of friendships at Boalt?

D. How do you think your pattern of friendships compares to that of other students at Boalt? Why do you think that other students have patterns of friendship (similar to/different from) yours?

\section{ADMISSIONS POLICY}

A. Do you know what procedures were used to admit the second- and third-year classes at Boalt? How would you describe them?

B. Do you know what procedures were used to admit the first-year class at Boalt? How would you describe them?

C. Do you know what changes have been made in the procedures to admit next year's entering class? What effect do you expect them to have on the make-up of the class?

D. Given the changes in admissions policy at the law school, what advice would you give to someone who was considering applying here? How do you think prospective applicants view the law school? How do you think that they form these views? Do you think that these perceptions are accurate or not? Why or why not?

E. If you could design an admissions policy for the law school, how would you set it up? Why would you choose these procedures?

\section{GENERAL QUESTIONS AND CONCLUSION}

A. We are getting some general descriptive data to use in the study. So, if someone were to ask you to describe yourself, what would you say?

B. We also need some specific data. In particular, we need to know your age and race or ethnicity. How old are you? How would you describe your racial or ethnic background?

C. Is there anything you would like to add before we conclude?

D. Thank you for sharing your views with me. Your participation is very important to the study's success, and I really appreciate your help. 


\section{Appendix B}

Vignettes on Race:

\section{Constitutional Law}

Katzenbach v. McClung (U.S. 1964): Under the Civil Rights Act of 1964, Congress prohibited restaurants from discriminating against customers on the basis of race. Congress based the legislation on its power to regulate interstate commerce. Ollie's Barbecue, a family restaurant in Birmingham, Alabama, offered table service to White customers and take-out service to Black customers. The restaurant had purchased about $\$ 150,000$ of food in the preceding year, $46 \%$ of which was meat bought from a local supplier. The supplier in turn purchased the meat from out of state. Although Ollie's Barbecue did buy a substantial portion of its supply from food that had moved in interstate commerce, it contended that Congress could not conclusively presume that racial discrimination by the restaurant would affect interstate commerce. The Umited States Supreme Court held that Congress could find that racial discrimination reduced per capita spending by Blacks, which in turn had an impact on interstate commerce. Moreover, racial discrimination had a direct and highly restrictive effect on Blacks' ability to travel across state lines. Finally, racial discrimination discouraged professionals and highly skilled people from moving into these areas and thus made industry reluctant to locate there. Although the amount of food purchased by Ollie's Barbecue was insignificant when compared with the total amount of food moving in commerce, its discriminatory practices contributed to the substantial, aggregate impact of these practices. Congress therefore was entitled to prohibit discrimination under these circumstances, even if it could not reach a restaurant when its effect on commerce was remote, isolated, and speculative.

\section{Property}

United States v. Starrett City Associates (2d Cir. 1988): The plaintiffs were applicants for housing in the defendant's apartment complex in Brooklyn. The plaintiffs alleged that their applications were rejected solely on the basis of race in violation of the Fair Housing Act. The defendant argued that it was necessary to maintaim a racial balance in the complex to ensure that the housing remained integrated. To that end, the defendant imposed racial ceilings so that the housing development would remain $64 \%$ White, $22 \%$ Black, and $8 \%$ Latino. Without such limits, the defendant argued that Whites would flee as the number of Blacks and Latinos grew beyond what was termed the "tipping" point. The Second 
Circuit Court of Appeals rejected the defendant's argument because the racial ceilings had been in place for ten years, and there was no clearcut point at which the ceilings would no longer be necessary. Moreover, the defendant's efforts to maintain a fixed level of integration prevented Blacks and Latinos from gaining access to scarce and highly desirable housing. One judge dissented, arguing that the maintenance of racial integration in housing was a goal that a private landlord could properly weigh under the Fair Housing Act.

\section{Criminal Law}

People v. Goetz (N.Y. 1986): The defendant Bernard Goetz entered a subway in New. York and chose a seat at the rear of the same car occupied by four youths. Two of the four carried screwdrivers inside their coats, which they said were used to break into the coin boxes of video machines. One of the youths asked Goetz to "give me five dollars." None of the youths displayed a weapon. In response, Goetz, who was carrying an unlicensed .38 caliber pistol loaded with five rounds of ammunition in a waistband holster, stood up, pulled out his gun, and fired four shots in rapid succession. He hit one youth in the chest, another in the back, a third in the arm and left side, and missed the fourth. Goetz then fired again and hit the fourth teenager in the back, severing his spinal cord. Other passengers fled the car when the shooting began. The conductor, who was in the next car, arranged for emergency assistance. Goetz told the conductor the young men had tried to rob him. While the conductor helped the injured teenagers, Goetz fled by foot. Although three of the teenagers fully recovered, one was left paralyzed. Goetz surrendered to police in Concord, New Hampshire nine days later. Goetz stated that he purchased the gun after being mugged. He said that he did not think that any of the youths was armed but he had a fear, based on prior experience, of being "maimed." $\mathrm{He}$ said that he shot the men in order to "murder [them], to hurt them, to make them suffer as much as possible." Goetz argued that he had acted in self defense. The New York Court of Appeals required that Goetz's fear for his own safety be reasonable. A New York jury apparently concluded that it was, acquitting Goetz on counts of attempted murder and assault and finding him liable only for carrying an unlicensed, concealed weapon. Critics of the jury verdict argued that the outcoine was influenced by the fact that the teenagers were Black, and Goetz was White. 
Vignettes on Gender:

Torts

Korman v. Mallin (Alaska 1993): The plaintiff consulted a plastic surgeon about breast reduction surgery. The plaintiff watched two videos about the procedure, and the surgeon told her that there was a risk of permanent scarring. The doctor, however, also reassured her not to worry about the procedure because he had done hundreds of them, and she would be happy with the results. The informed consent form indicated that as a smoker, plaintiff had a higher risk of scarring. After the surgery, the plaintiff wound up with unsightly, painful scars. She alleged that had the doctor fully informed her about the risks of permanent scarring, she would not have undergone the surgery. The court adopted a "patient rule," which required the doctor to disclose what a reasonable patient would want to know. In this way, patients would have a meaningful right to control their own bodies. The court rejected a "physician rule," which would allow doctors to disclose only what other physicians customarily told their patients.

\section{Contracts}

In the Matter of Baby M. (N.J. 1988): This case involved a surrogacy arrangement in which Mary Beth Whitehead agreed to bear a child for William and Elizabeth Stern, an affluent couple unable to have children of their own. William Stern was particularly committed to having children because most of his family had been killed during the Holocaust, and he was the only survivor. Whitehead, who was married and already had children of her own, was inseminated with Stern's sperm. After bearing the child, she was to relinquish the newborn to the Sterns for adoption. Whitehead would have no further contact with the child. In exchange for carrying the child, the Sterns were to pay her $\$ 10,000$. After the birth of the child, Whitehead turned her over as agreed but subsequently suffered from unbearable sadness at being separated from the baby. She asked the Sterns to let her have the baby, if only for a short time, to ease her despair. The Sterns agreed to let her have the child for a week, but afterwards Whitehead would not turn the child over and eventually fled to another state in order to keep custody of her. The Sterns sued for enforcement of the surrogacy contract, but the New Jersey Supreme Court held that it was unenforceable as against public policy. However, William Stern did win custody of the child as the biological father based on the best interest of the child, and Whitehead was given visitation rights. 


\section{Criminal Law}

State v. Kelly (N.J. 1984): The defendant Gladys Kelly stabbed her husband with a pair of scissors and killed him. She admitted stabbing him, but she argued that she had acted in self defense because she was a battered woman. The defendant claimed that her late husband had frequently beaten her, generally when he was drunk. Throughout their sevenyear marriage, he promised to change his ways, but the violence continued. The day that she stabbed her husband, she had gone to a friend's house with their daughter to ask him for money for food. He told her to wait until they got home, and he began walking back with her. Then, drunk and angry that she had come looking for him, he choked her until she felt as though she were "passing out" as a small crowd gathered to watch. Two of the men separated her from her husband. Shortly thereafter, her husband came running towards her with his hands raised. The defendant testified that she intended to scare him with the scissors but instead stabbed him. The trial court refused to admit expert testimony on the battered woman's defense, and the defendant was convicted of reckless manslaughter. The New Jersey Supreme Court reversed because it concluded that the expert testimony was relevant to whether the defendant honestly believed that she was in imminent danger of death. This evidence was relevant to the jury as it assessed the reasonableness of the fear that she felt when she allegedly acted in self defense. 